Nevada

Environmental

Restoration

Project

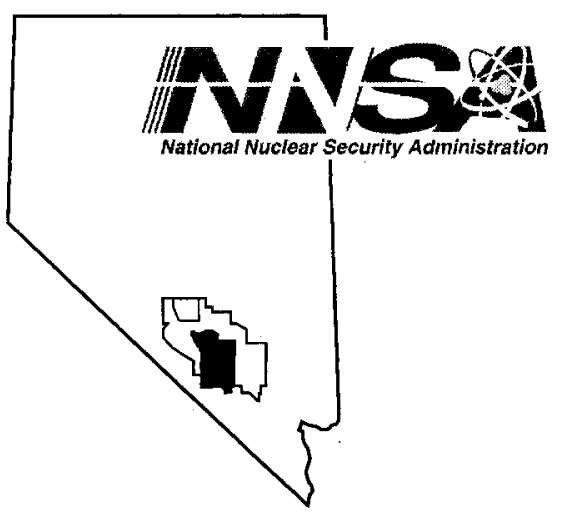

Closure Report for Corrective

Action Unit 167: Contaminated

Materials and Trash Pits,

Nevada Test Site, Nevada

Controlled Copy No.:

Revision: 1

April 2005

Environmental Restoration 


\section{DISCLAIMER}

Reference herein to any specific commercial product, process, or service by trade name, trademark, manufacturer, or otherwise, does not necessarily constitute or imply its endorsement, recommendation, or favoring by the U.S. Government or any agency thereof or its contractors or subcontractors.

This report has been reproduced directly from the best available copy.

Available for sale to the public from:

U.S. Department of Commerce

National Technical Information Service

5285 Port Royal Road

Springfield, VA 22161-0002

Telephone: (800) 553-6847

Fax: (703) 605-6900

E-mail: orders@ntis.gov

Online ordering: http://www.ntis.gov/ordering.htm

Available electronically at http://www.osti.gov/bridge.

Available for a processing fee to the U.S. Department of Energy and its contractors, in paper, from:

U.S. Department of Energy

Office of Scientific and Technical Information

P.O. Box 62

Oak Ridge, TN 37831-0062

Telephone: (865) 576-8401

Fax: (865) 576-5728

E-mail: reports@adonis.osti.gov 


\title{
CLOSURE REPORT FOR CORRECTIVE ACTION UNIT 167: CONTAMINATED MATERIALS AND TRASH PITS, NEVADA TEST SITE, NEVADA
}

\author{
U.S. Department of Energy \\ National Nuclear Security Administration \\ Nevada Site Office \\ Las Vegas, Nevada
}

Controlled Copy No:

Revision: 1

April 2005 
THIS PAGE INTENTIONALLY LEFT BLANK 


\section{CLOSURE REPORT FOR CORRECTIVE ACTION UNIT 167: CONTAMINATED MATERIALS AND TRASH PITS, NEVADA TEST SITE, NEVADA}

Approved By: $\frac{\text { Jandt L. Appenteler-Wing, Project Manager }}{\text { Industrial Sites Project }}$

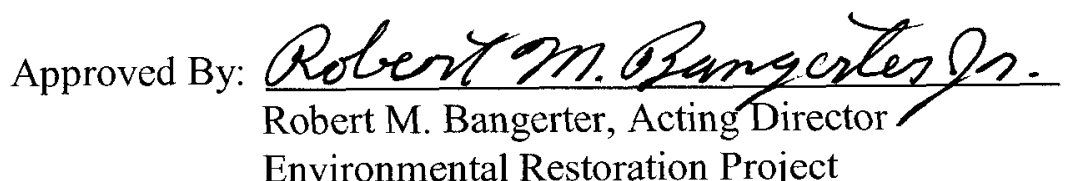

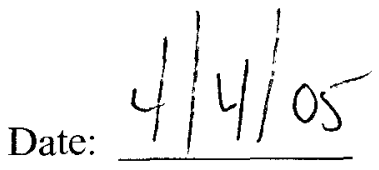

Date: $4 / 4 / 05$ 
THIS PAGE INTENTIONALLY LEFT BLANK 


\section{TABLE OF CONTENTS}

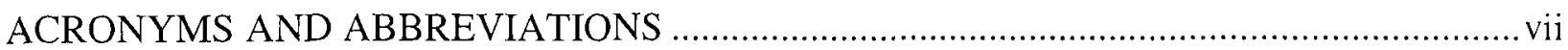

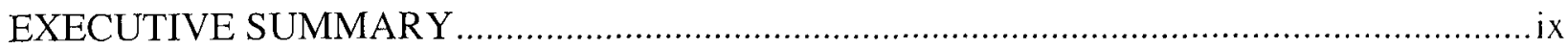

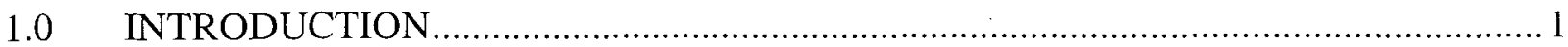

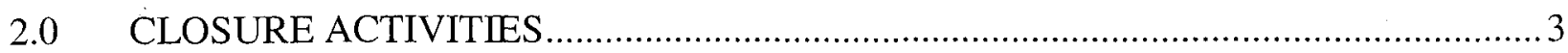

2.1 DESCRIPTION OF CLOSURE ACTIVITIES ………….......................................... 3

2.1.1 Preplanning and Site Preparation........................................................ 3

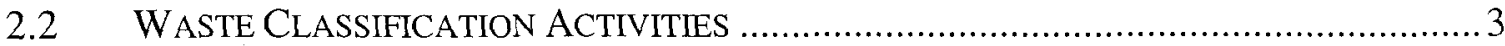

2.2.1 CAS 05-99-05: Combat Tank;

Radioactive Material Waste Classification .............................................. 3

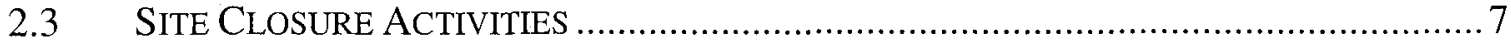

2.3.1 CAS 05-99-05: Combat Tank; Radioactive Material ............................. 7

2.3.2 CAS 19-19-02: Trash Pit .................................................................... 10

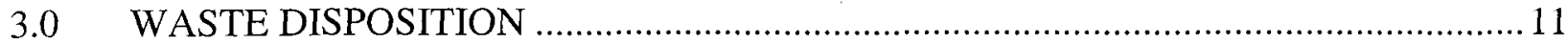

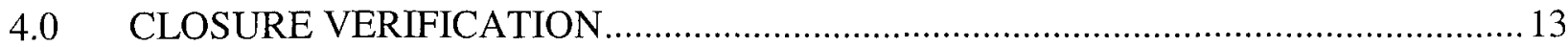

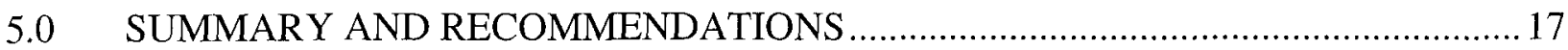

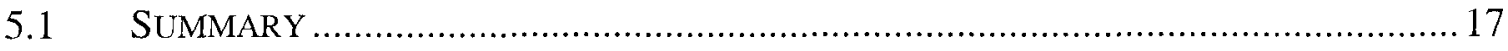

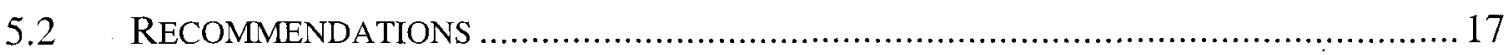

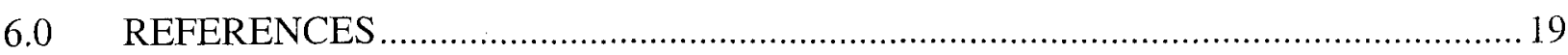

\section{FIGURES}

FIGURE 1. CAU 167 SITE LOCATION MAP ……....................................................................

Figure 2. CAS 05-99-05 COMBAT TANK; RADIOACTIVE MATERIAL, SOIL WATE CLASSIFICATION SAMPLE LOCATIONS ………...................................... 6

FiguRe 3. CAS 05-99-05 COMBAT TANK; Radioactive Material, CLOSURE VERIFICATION SAMPLES

\section{TABLES}

Table 1. Summary of ANALytical Results For Waste Classification SAMPLES .................. 4

TABLE 2. SUMMARY OF ANALYTICAL RESULTS FOR VERIFICATION SAMPLES ................................ 13 


\section{TABLE OF CONTENTS (continued)}

\section{APPENDICES}

APPENDIX A: SAMPLE ANALYTICAL RESULTS

A-1

APPENDIX B: SECTORED HOUSEKEEPING SITE CLOSURE

VERIFICATION FORMS

APPENDIX C: NATIONAL ENVIRONMENTAL POLICY ACT

EVALUATION CHECKLIST

APPENDIX D: NEVADA ENVIRONMENTAL RESTORATION PROJECT

DOCUMENT REVIEW SHEET

LIBRARY DISTRIBUTION LIST 


\section{ACRONYMS AND ABBREVIATIONS}

\begin{tabular}{|c|c|}
\hline bgs & below ground surface \\
\hline $\mathrm{BN}$ & Bechtel Nevada \\
\hline CAS & Corrective Action Site(s) \\
\hline $\mathrm{CAU}$ & Corrective Action Unit(s) \\
\hline DRO & Diesel-range organics \\
\hline DU & Depleted Uranium-238 \\
\hline EPA & U.S. Environmental Protection Agency \\
\hline $\mathrm{ft}$ & foot (feet) \\
\hline FFACO & Federal Facility Agreement and Consent Order \\
\hline $\mathrm{mg} / \mathrm{kg}$ & milligram(s) per kilogram \\
\hline NAC & Nevada Administrative Code \\
\hline NCCT & National Center for Combating Terrorism \\
\hline ND & Not Detected \\
\hline NDEP & Nevada Division of Environmental Protection \\
\hline NNSA/NSO & $\begin{array}{l}\text { U.S. Department of Energy National Nuclear Security Administration } \\
\text { Nevada Site Office }\end{array}$ \\
\hline NS & Not Sampled \\
\hline PCB & polychlorinated biphenyl(s) \\
\hline $\mathrm{pCi} / \mathrm{g}$ & picoCuries per gram \\
\hline PRG & Preliminary Remediation Goal(s) \\
\hline RCRA & Resource Conservation and Recovery Act \\
\hline RMA & Radiological Materials Area \\
\hline $\mathrm{SDG}$ & Sample Delivery Group \\
\hline
\end{tabular}




\section{ACRONYMS AND ABBREVIATIONS (continued)}

$\begin{array}{ll}\text { SVOC } & \text { Semivolatile Organic Compound(s) } \\ \text { TPH } & \text { Total Petroleum Hydrocarbons } \\ \text { USGS } & \text { United States Geological Survey } \\ \text { VOC } & \text { Volatile Organic Compound(s) } \\ \text { WW } & \text { Water Well } \\ \mathrm{yd}^{3} & \text { cubic yard(s) }\end{array}$




\section{EXECUTIVE SUMMARY}

Corrective Action Unit (CAU) 167 consists of two Corrective Action Sites (CASs) located in Areas 5 and 19 of the Nevada Test Site. The closure activities performed at the two CASs are listed below.

\section{CAS 05-99-05, Combat Tank; Radioactive Material}

- Transfer of ownership of the tank to the National Center for Combating Terrorism (NCCT), part of the U. S. Department of Energy, National Nuclear Security Administration. The tank was relocated from the CAS to a controlled area in Area 1 of the NTS and is currently used as a training aid by the NCCT.

- Performing a radiological survey of the area resulting in the deposting of the area as a RMA.

- Removal and disposal of surface debris including fence posts and a wooden pallet.

- Collecting and analyzing soil waste classification samples from the site.

- Removal and disposal of approximately 40 cubic yards of petroleum hydrocarbon impacted soil from beneath the former location of the tank. The extent of the excavation was determined by field screening of hydrocarbons.

- Collecting and analyzing soil verification samples from the site excavation.

- Backfilling the excavation with clean fill and compacting by wheel rolling with heavy equipment.

- Performing an "A through K" risk assessment to determine the risk to health and the environment posed by leaving low concentrations of hydrocarbons in soil in the shallow subsurface.

\section{CAS 19-19-02, Trash Pit:}

Documenting that the waste originally identified was no longer present on site. No further closure activities were necessary at this CAS.

Two CASs that were originally part of CAU 167 were transferred out of CAU 167 with approval by the Nevada Division of Environmental Protection. CAS 18-99-06 (Core in Boxes) was evaluated and submitted for classification as an historical site and transferred into CAU 5000, Archived Corrective Action Sites. CAS 18-99-08 (Core in Boxes) was transferred into CAU 286 for closure at a future date. 
Revision: 1

Date: April 2005

THIS PAGE INTENTIONALLY LEFT BLANK 


\subsection{INTRODUCTION}

This report documents that the closure activities conducted for Corrective Action Unit (CAU) 167: Contaminated Materials and Trash Pits, met the approved closure standards. CAU 167 is listed in Appendix III of the Federal Facility Agreement and Consent Order (FFACO, 1996) and consists of two Corrective Action Sites (CAS) located in Areas 5 and 19 of the Nevada Test Site (NTS) (Figure 1):

- CAS 05-99-05: Combat Tank; Radioactive Material

- CAS 19-19-02: Trash Pit

Two CASs that were originally part of CAU 167 were transferred out of CAU 167 with approval by the Nevada Division of Environmental Protection (NDEP). CAS 18-99-06 (Core in Boxes) was evaluated and submitted for classification as an historical site and transferred into CAU 5000, Archived Corrective Action Sites. CAS 18-99-08 (Core in Boxes) was transferred into CAU 286 for closure at a future date.

Closure activities at the two remaining CASs consisted of documenting current site conditions, identifying and removing debris and contaminated soil, classifying and disposing of the generated waste, collecting and analyzing soil verification samples, verifying that each site was clean of debris by visual inspection, and deposting a radiologically controlled area.

Copies of analytical results are included in Appendix A. Copies of the "Sectored Housekeeping Site Closure. Verification Forms" for CAS 05-99-05 and 19-19-02 are included in Appendix B. A copy of the "National Environmental Policy Act Evaluation Checklist" for CAU 167 is included in Appendix C, and a complete Document Review Sheet addressing comments received on Revision 0 of this report is included in Appendix D. 


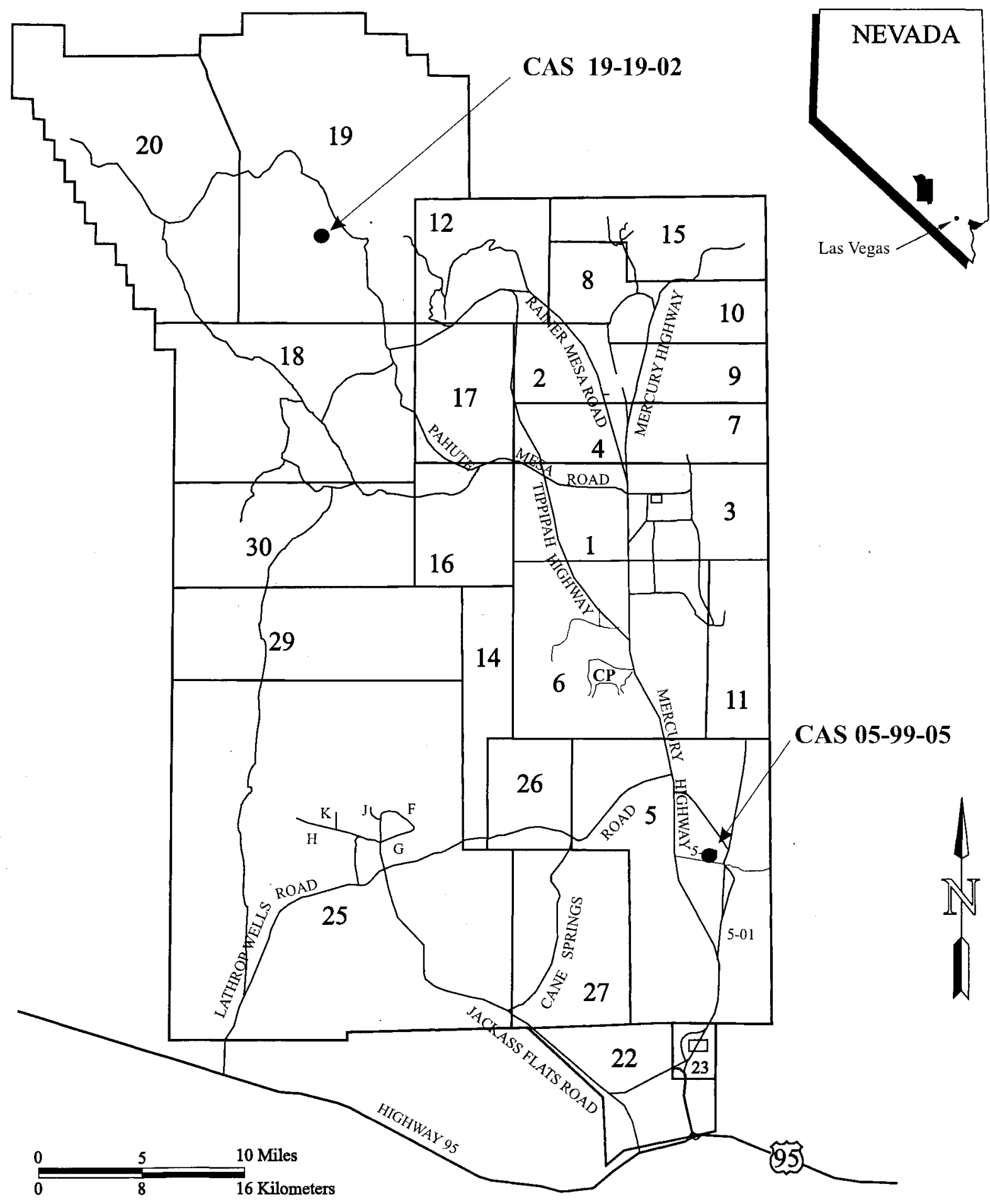

FIGURE 1

CAU 167 SITE LOCATION MAP 


\subsection{CLOSURE ACTIVITIES}

This section details the specific closure activities completed for CAU 167: Contaminated Materials and Trash Pits.

\subsection{Description of Closure ACtivities}

\subsubsection{Preplanning and Site Preparation}

Planning documents prepared prior to the beginning of closure activities include the following:

- $\quad$ Sectored Clean-up Work Plan For Housekeeping Category Waste Sites (National Nuclear Security Administration Nevada Site Office [NNSA/NSO], 2003b).

- Generic Field Management Plan for Housekeeping Category Waste Sites (NNSA/NSO, 2003a).

- Site-Specific Health and Safety Plan for Corrective Action Units 167, 210, 286, 390, and 395 Housekeeping Sites, Nevada Test Site, Nevada (Bechtel Nevada [BN], 2003).

- BN Solid Waste Operations (SWO) Work Packages.

- $\quad$ NNSA/NSO Real Estate/Operation Permit.

\subsection{Waste Classification ACtivities}

Neither of the CAU 167 CASs was previously sampled for waste classification, and process knowledge was insufficient to classify the potential waste at each site. During site visits, one site was found to have a potential waste stream requiring waste classification. Therefore at CAS 05-99-05, soil samples were collected and analyzed to classify waste at the site and determine the appropriate waste disposal pathway. The samples were collected with clean disposable plastic scoops, placed in labeled sample containers, and secured with custody seals. The sample containers were placed on ice in a cooler, transported under chain of custody to the BN Environmental Technical Services group in Mercury, Nevada, and shipped to an off-site laboratory for analysis. An additional six soil samples were collected to characterize the soil under the tank after the tank was physically transferred to Area 1 of the NTS. Table 1 summarizes the results of laboratory analyses performed for the waste characterization samples. Appendix A contains the analytical reports for the waste characterization samples.

\subsubsection{CAS 05-99-05: Combat Tank; Radioactive Material Waste Classification}

This site consisted of an M-47 combat tank located within a posted Radiological Materials Area (RMA). The combat tank was used as a target for armor-piercing ammunition that contained depleted uranium-238 (DU).

During a 2003 site visit, two small areas of soil staining were noted at the rear of the tank. The stains appeared to be oil that had leaked from the gearboxes at the rear of the tank. There was no evidence of recent leakage during any of the site visits. Six soil waste classification samples were collected from five locations around the tank to determine if the soil in the vicinity of the 
Table 1. Summary of Analytical Results for Waste Classification Samples

\begin{tabular}{|c|c|c|c|c|c|c|}
\hline $\begin{array}{l}\text { SAMPLE } \\
\text { IDENTIFICATION }\end{array}$ & 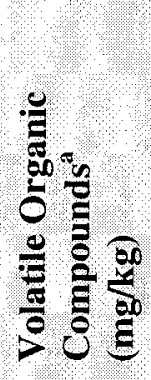 & 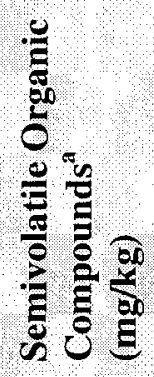 & 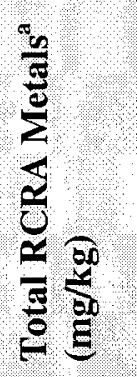 & 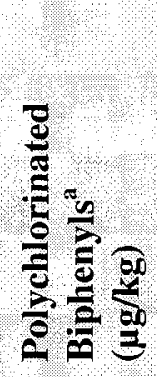 & 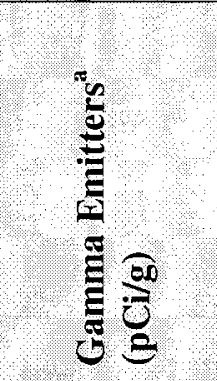 & 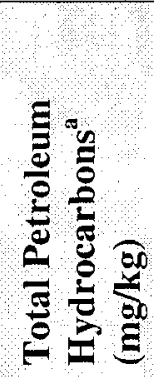 \\
\hline 059905 L REAR & ND & ND & $<\mathrm{PRGs}$ & ND & $\mathrm{U}-238 \quad 0.913$ & 80 \\
\hline $059905 \mathrm{LEFT}^{\mathrm{c}}$ & ND & ND & $<$ PRGs & ND & U-238 18.0 & 150 \\
\hline 059905 FRONT & ND & ND & $<$ PRGs & ND & U-238 3.76 & 58 \\
\hline 059905 RIGHT & ND & ND & $<$ PRGs & ND & U-238 5.52 & $<20$ \\
\hline 059905 R REAR & ND & ND & $<\mathrm{PRGs}$ & ND & U-238 0.776 & 83 \\
\hline $\begin{array}{l}\text { DUP A (Duplicate of } \\
\text { 059905 L REAR) }\end{array}$ & ND & $\mathrm{ND}$ & $<$ PRGs & ND & U-238 1.42 & $<20$ \\
\hline $\begin{array}{l}059905 \mathrm{~V} \\
\text { (Verification sample } \\
\text { collected at location of } \\
059905 \text { LEFT) }\end{array}$ & NS & NS & NS & NS & NS & $<20$ \\
\hline $059905 \mathrm{~V} 1$ & NS & NS & NS & 490 & NS & 2,350 \\
\hline $059905 \mathrm{~V} 2$ & NS & NS & NS & 150 & NS & 3,730 \\
\hline $059905 \mathrm{~V} 3$ & NS & NS & NS & 860 & NS & 10,200 \\
\hline $059905 \mathrm{~V} 4$ & NS & NS & NS & 390 & NS & 32,000 \\
\hline $059905 \mathrm{~V} 5$ & NS & NS & NS & 46 & NS & 26,000 \\
\hline $059905 \mathrm{~V} 6$ & NS & NS & NS & 55 & NS & 12,900 \\
\hline $\begin{array}{l}\text { DUP C } \\
\text { (Duplicate of 059905V2) }\end{array}$ & NS & NS & NS & $\mathrm{ND}^{\mathrm{d}}$ & NS & 880 \\
\hline
\end{tabular}

Results reported in bold indicate concentration above action levels.

a Volatile Organic Compounds (VOCs), Semivolatile Organic Compounds (SVOCs), total Resource Conservation and Recovery Act (RCRA) Metals, Polychlorinated Biphenyls (PCBs), Total Petroleum Hydrocarbons (TPH), Gamma, and Gross Alpha/Beta samples analyzed by U.S. Environmental Protection Agency (EPA) SW-846 Method 8260, 8270, 6010 and 7470, 8082, 8015 modified, 901.1 and 906.0 respectively (EPA, 1996). See analytical reports in Appendix A for laboratory detection limits.

b $<$ PRGs = Analytical results indicated that the levels of contaminants were less than the EPA Region IX Preliminary Remediation Goals (PRGs) for industrial soils (EPA, 2002).

${ }^{c}$ High organic content noted in sample.

d Laboratory reported interference in analysis.

Definitions:

$\mathrm{mg} / \mathrm{kg}=$ milligrams $(\mathrm{s})$ per kilogram

$\mu \mathrm{g} / \mathrm{kg}=\operatorname{microgram}(\mathrm{s})$ per kilogram

$\mathrm{ND}=$ Not Detected at laboratory reporting limit or less than laboratory Minimum Detectable Activity. See Appendix A for limits.

NS $=$ Not Sampled

$\mathrm{pCi} / \mathrm{g}=$ picoCuries per gram 
tank was impacted with contaminants of concern. Samples were collected from the stains at the rear of the tank and from the soil near the other three sides of the vehicle (Figure 2). In the process of sampling, the stained soil areas at the rear of the tank were completely removed. Five of the samples (including one duplicate) were collected on November 7, 2003, at a depth of approximately 2-3 inches below ground surface (bgs). The samples were analyzed for volatile organic compounds (VOC), semivolatile organic compounds (SVOC), total Resource Conservation and Recovery Act (RCRA) metals, total petroleum (gasoline, diesel, and motor oil range) hydrocarbons (TPH), polychlorinated biphenyls (PCBs), and gamma emitters. Analytical results for the five samples were below action levels for industrial soils for VOCs, SVOC, total RCRA metals, PCBs (U.S. Environmental Protection Agency [EPA], 2002), and for gamma emitters (NDEP, 2004) (Table 1). Four of the five samples had TPH concentration less than the State of Nevada action level of 100 milligrams per kilogram $(\mathrm{mg} / \mathrm{kg})($ Nevada Administrative Code, 2003) (Table 1).

Sample "059905 LEFT," collected from the left (south) side of the tank (not one of the stained areas), had a TPH concentration of $150 \mathrm{mg} / \mathrm{kg}$. An additional sample, $059905 \mathrm{~V}$, was collected from the same location on January 9, 2004. This sample was collected from the bottom of the original sample site at a depth of 4-5 inches bgs, and analyzed for TPH only. TPH results for Sample $059905 \mathrm{~V}$ indicated TPH concentrations less than the Nevada action level of $100 \mathrm{mg} / \mathrm{kg}$ (Table 1). Based on these results, it was determined that the remaining soil outside the footprint of the tank was not impacted with TPH above action levels at the surface. Additional visual observations and sampling under the tank footprint were performed after the tank was removed from the site.

In addition, analytical results for gamma emitters indicated DU concentration slightly greater than NTS background levels, but below the revised preliminary action level for U-238 of 63 picoCuries per gram (pCi/g) (NDEP, 2004). The tank was impacted with DU and the site was originally a posted RMA. The analytical data summaries for the soil samples are included in Appendix A and summarized in Table 1.

A radiological survey of the tank was performed and it was determined that the tank did not have any removable radiological contamination on the exterior, but did have fixed contamination present. Because the tank was used as a target, the interior of the tank is expected to be contaminated as well. However, all of the access hatches were locked and any punctures were secured with tape prior to moving the tank.

Ownership of the combat tank was transferred to the National Center for Combating Terrorism (NCCT) group and the tank was relocated to the NCCT training area at the T-1 site in Area 1 of the NTS on September 24, 2004. The tank will be used as training aid by the NCCT, and is therefore, no longer considered a waste.

After the tank was moved, the area beneath the former location of the tank was visually inspected for staining, and field screened for TPH and radiological contaminants. Based on the visual inspection and field screening, a total of seven additional soil waste classification samples (059905V1 - V6, DUP C) were collected on October 6, 2004 from the area formerly under the tank (Figure 2). The soil samples were analyzed for TPH and PCBs based on previous sampling 
DRY LAKE BED

(FRENCHMAN LAKE)

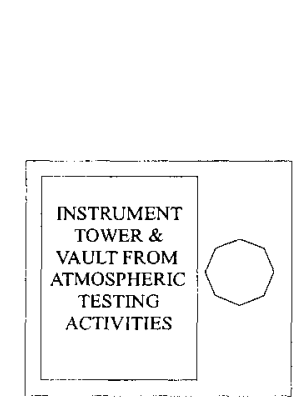

FORMER RMA BOUNDARY FENCE

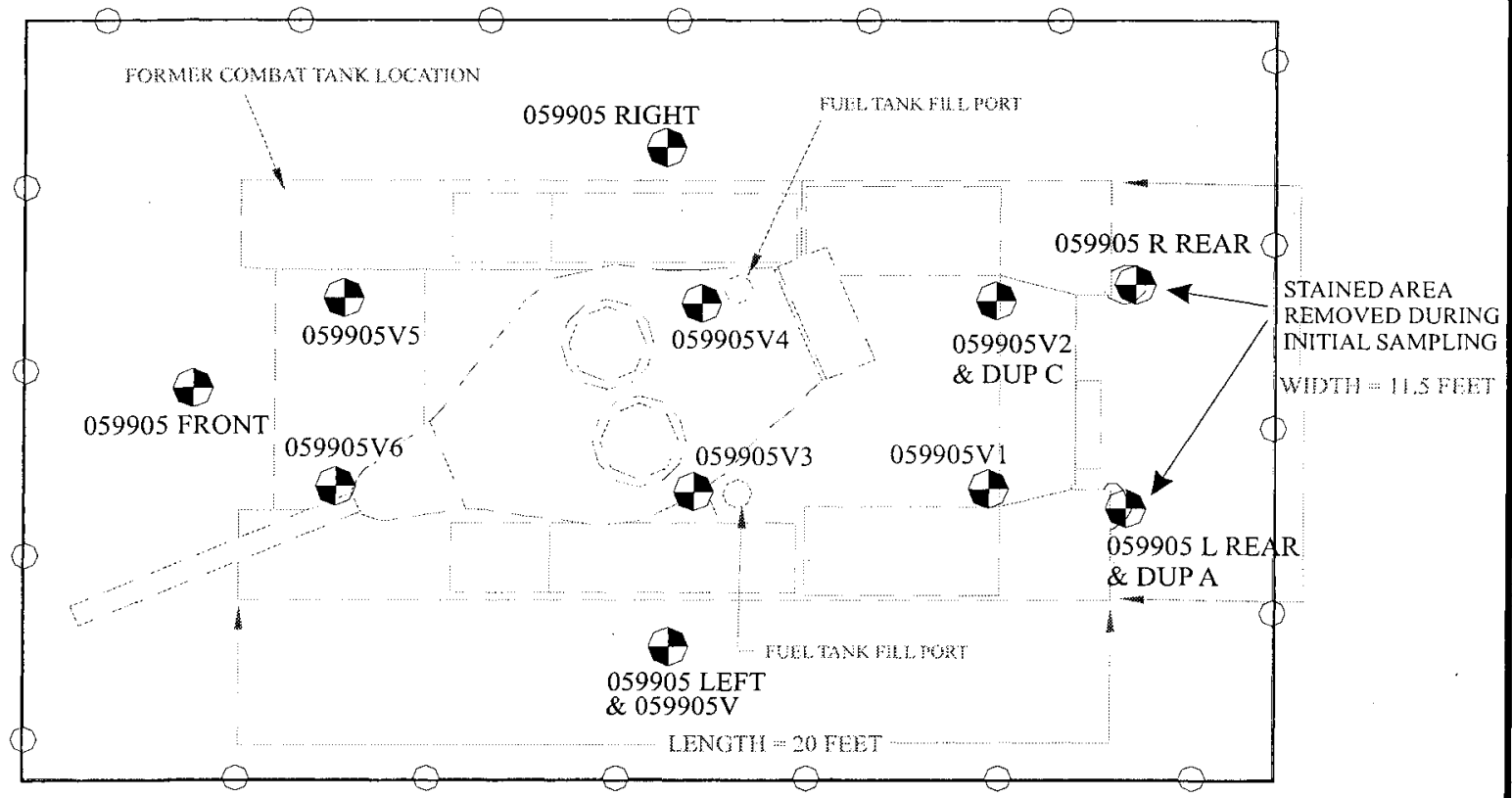

FORMER RMA BOUNDARY FENCE

DRY LAKE BED

(FRENCHMAN LAKE)

\section{FIGURE 2} SOIL WASTE CLASSIFICATION SAMPLE LOCATIONS 
results and process knowledge of potential hydrocarbon releases from the tank. The analytical data results for the soil samples are included in Appendix A and summarized in Table 1. The analytical results indicated that concentrations of oil and diesel range TPH were above the Nevada action level of $100 \mathrm{mg} / \mathrm{kg}$ at all six sample locations. Based on these results, additional closure activities were required to be close this site. The analytical data summaries for the soil samples are included in Appendix A and summarized in Table 1.

\subsection{Site Closure Activities}

Appendix B includes the "Housekeeping Site Closure Verification Forms," including site information and before and after site photographs.

\subsubsection{CAS 05-99-05: Combat Tank; Radioactive Material}

Closure activities at CAS 05-99-05 included the following:

- Transfer of ownership of the tank to the National Center for Combating Terrorism (NCCT), part of the U. S. Department of Energy, National Nuclear Security Administration. The tank was relocated from the CAS to a controlled area in Area 1 of the NTS and is currently used as a training aid by the NCCT.

- Performing a radiological survey of the area resulting in the deposting of the area as a RMA.

- Removal and disposal of surface debris including fence posts and a wooden pallet.

- Collecting and analyzing soil waste classification samples from the site.

- Removal and disposal of approximately $40 \mathrm{yd} 3$ of TPH impacted soil from beneath the former location of the tank. The extent of the excavation was determined by TPH field screening.

- Collecting and analyzing soil verification samples from the site excavation.

- Backfilling the excavation with clean fill and compacting by wheel rolling with heavy equipment

A final radiological survey of the entire RMA was conducted and the site was deposted on October 30, 2004.

On December 7, 2004, after the tank was removed from the site, TPH-impacted soil from the area beneath the tank was excavated and removed from the site on. The initial excavation covered the entire area beneath the tank to a depth of 27 inches bgs (Figure 3). Soil was collected from six locations within the former footprint of the tank treads, and field screened for TPH using Petroflag ${ }^{\circledR}$ field screening kit. Screening results indicated that TPH concentrations were below $75 \mathrm{mg} / \mathrm{kg}$ at four locations on the south and in the northwest and northeast corners of the excavation. Based on the screening results, four soil verification samples (059905V8 - V11) were collected and submitted for laboratory analysis. At two locations near the center of the tank screening showed TPH concentrations greater than $75 \mathrm{mg} / \mathrm{kg}$. For this reason, the center of the initial excavation was over-excavated to a depth of $11 \mathrm{ft}$ bgs (Figure 3). A soil sample was collected at the base of the over excavated area and field screened for TPH. Field screening showed TPH concentrations less than $75 \mathrm{mg} / \mathrm{kg}$, hence, two soil verification samples (059905V12, DUP D) were collected and submitted for laboratory analysis. The excavation was backfilled with clean fill material and compacted by wheel rolling with heavy equipment. 
Laboratory results for four of the five verification samples showed that no TPH remained on site at concentrations above the Nevada action level of $100 \mathrm{mg} / \mathrm{kg}$ (See Section 4.0). Verification sample $059905 \mathrm{~V} 9$ collected from the center of the north side of the initial 27 inch deep excavation had a result of $700 \mathrm{mg} / \mathrm{kg}$. This was unexpected given the TPH field screening result of $60 \mathrm{mg} / \mathrm{kg}$ from the sample location.

Because of this result the site can not be considered clean of TPH contamination. To assess the risk to health and the environment due to leaving low concentrations of TPH on site in the shallow subsurface, an "A through K" risk assessment per the Nevada Administrative Code (NAC, 2002) was made. Based on the "A though K" risk assessment the TPH remaining on site poses little or no risk to health and the environment (See Section 4.0). For this reason no further action was taken to close this site.

\subsubsection{CAS 19-19-02: Trash Pit}

The drums originally identified in Appendix II of the FFACO (FFACO, 1996) were not present during a 2003 site visit. The drums were originally located in a trash pit near the U-19ab ground zero from the 1985 "Towanda" test (DOE/NV, 2000). Additional wood and scrap metal debris is located at the site but could not be removed because the 1985 test did not result in a subsidence feature (crater) at the ground surface. As the area has the potential to subside/collapse, the area is inaccessible to workers. Site conditions were documented with photographs (Appendix B) and field notes. No further action is required at this site. 


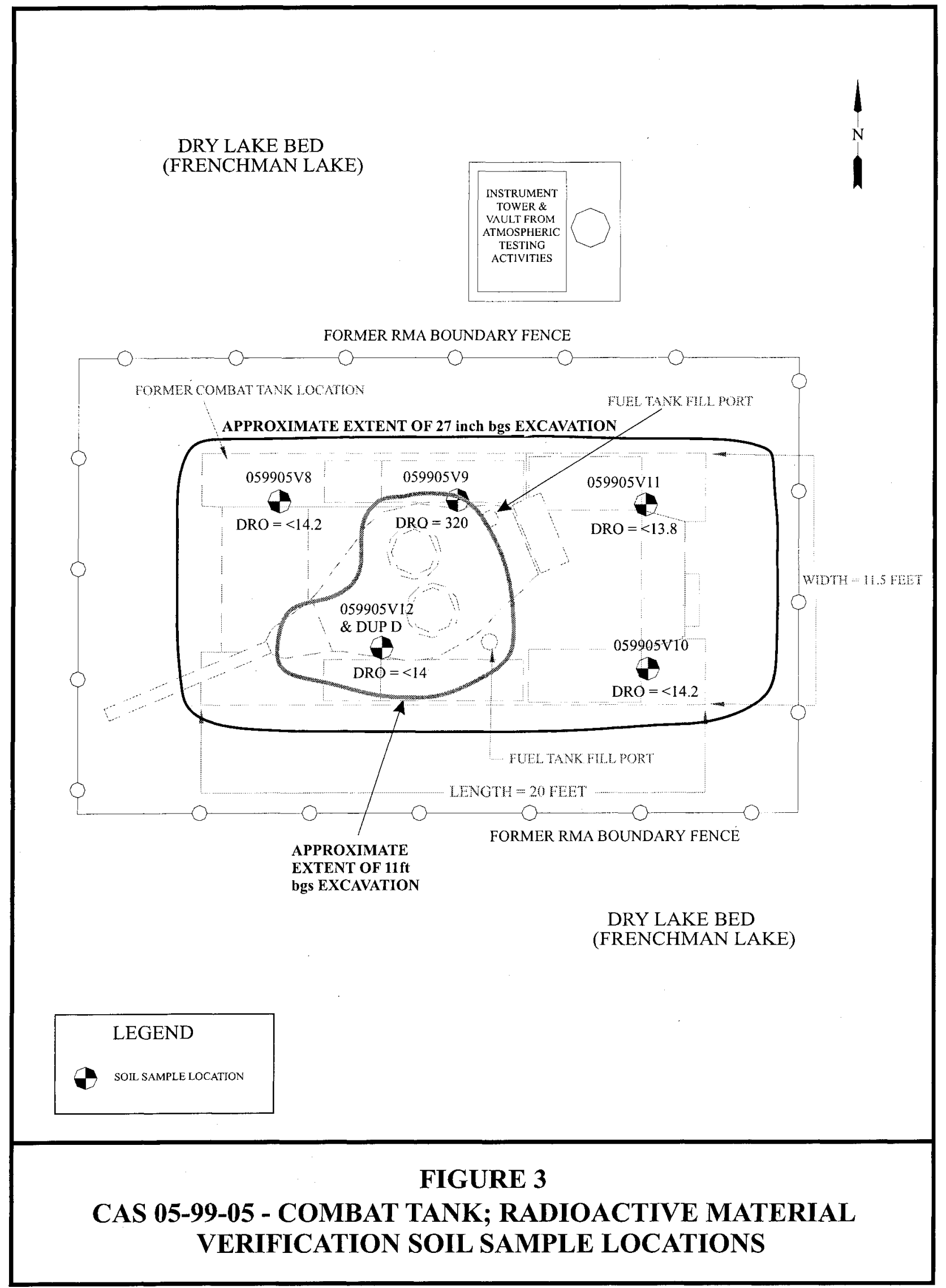


Closure Report - CAU 167

Section: Closure Activities

Revision: 1

Date: April 2005

THIS PAGE INTENTIONALLY LEFT BLANK 


\subsection{WASTE DISPOSITION}

Waste was generated during the closure of CAU 167 only at CAS 05-99-05. The site originally consisted of a combat tank and a small amount of surface debris. The combat tank was relocated to Area 1 on September 24, 2004, for use as a training aid and it is no longer considered a waste. The RMA was radiologically surveyed and deposted on October 30, 2004. This activity generated a limited amount of waste including a wood pallet, scrap metal, and the fence posts from the RMA. The waste was radiologically screened, released, and disposed of in the Area 9 U10c Landfill.

After the tank was moved off site, it was observed that the soil beneath the tank location was stained and had a hydrocarbon odor. Field screening and waste characterization samples confirmed the soil was contaminated with TPH diesel-range organics (DRO) at concentrations greater than the Nevada action level of $100 \mathrm{mg} / \mathrm{kg}$. Therefore, approximately $40 \mathrm{yd}^{3}$ of $\mathrm{TPH}$-impacted soil was excavated from the site and disposed of in the Area 6 Hydrocarbon Landfill. 
Revision: 1

Date: April 2005

THIS PAGE INTENTIONALLY LEFT BLANK 


\subsection{CLOSURE VERIFICATION}

Closure activities at CAS 05-99-05 included collecting soil verification samples. Copies of the analytical results for the verification samples are included in Appendix A (See results for Sample Delivery Group V2376). Copies of the "Sectored Housekeeping Site Closure Verification Forms" for the two CASs 05-99-05 and 19-19-02 are included in Appendix B.

\section{CAS 05-99-05: Combat Tank; Radioactive Material}

Site closure activities included removing approximately $40 \mathrm{yd}^{3}$ of TPH-impacted soil from the area under the former location of the tank. A total of five soil verification samples were collected from the excavation and submitted for TPH-DRO analysis (Figure 3 ). Results for the soil samples verify that the majority of the TPH-impacted soil was successfully removed from the site (Table 2). One soil sample exceeded the Nevada action level for TPH. In addition, housekeeping waste such as scrap metal, wood pallets, and fence posts were removed and disposed of in the Area 9 U10c Landfill.

\section{Table 2. Summary of Analytical Results for Verificatión Samples}

\begin{tabular}{|c|c|c|c|}
\hline $\begin{array}{c}\text { SAMPLE } \\
\text { IDENTIFICATION }\end{array}$ & $\begin{array}{c}\text { Sample } \\
\text { Date }\end{array}$ & $\begin{array}{c}\text { Sample Depth } \\
\text { (feet) }\end{array}$ & $\begin{array}{c}\text { Total Petroleum } \\
\text { Hydrocarbons } \\
\text { (mg/kg) }\end{array}$ \\
\hline $059905 \mathrm{~V} 8$ & December 7, 2004 & 2.08 & 85.0 \\
\hline $059905 \mathrm{~V} 9$ & December 7, 2004 & 2.25 & $\mathbf{7 0 0 . 0}$ \\
\hline $059905 \mathrm{~V} 10$ & December 7, 2004 & 0.91 & 23.0 \\
\hline $059905 \mathrm{~V} 11$ & December 7, 2004 & 2.0 & 19.0 \\
\hline $059905 \mathrm{~V} 12$ & December 7, 2004 & 11.0 & 16.0 \\
\hline DUP D (duplicate of 059905V12) & December 7, 2004 & 11.0 & 14.0 \\
\hline
\end{tabular}

Results reported in bold indicate concentration above action levels.

a Total Petroleum Hydrocarbons (TPH) samples analyzed by U.S. Environmental Protection Agency (EPA) SW-846 Method 8015 modified, See analytical reports in Appendix A for laboratory detection limits.

Definitions:

$\mathrm{mg} / \mathrm{kg}=$ milligrams $(\mathrm{s})$ per kilogram

Because of the TPH results for sample $059905 \mathrm{~V} 9$, the site was evaluated for closure by taking No Further Action using the Nevada "a through k" guidelines pursuant to Nevada Administrative Code (NAC) 445A.227 (NAC, 2002). The evaluation follows below.

\section{a. Depth to Groundwater}

The depth to groundwater in the Frenchman Lake area ranges from 680 to $720 \mathrm{ft}$ bgs. The majority of groundwater flowing beneath the Frenchman Flat basin passes through the lower carbonate rock aquifer. This aquifer is the only subsurface pathway by which groundwater leaves the basin. Flow of water into, through, and out of the lower carbonate-rock aquifer 
beneath these basins is controlled in part by the occurrence of low-permeability rocks both above and laterally adjacent to the aquifer, lateral continuity with upgradient and downgradient sections of the lower carbonate-rock aquifer, the occurrence of faults, and secondary rock openings both within rocks of and adjacent to the lower carbonate-rock aquifer (fractures, joints, and dissolution openings).

\section{b. Distance to Irrigation or Drinking Water Wells}

Water Wells (WW) 5a, 5b, and 5c are located near CAS 05-99-05. The aquifer of WW-5a consists of consolidated deposits, while the aquifers of WW-5b and WW-5c contain valley fill deposits (USGS, 2002). WW-5a, located approximately 2.5 miles southwest of the CAS, is currently an active well used for drinking water. This well was drilled to a depth of $877 \mathrm{ft}$ bgs with the approximate water level being $710 \mathrm{ft}$ bgs (USGS, 2002). WW-5b is west of the CAS by approximately 1.4 miles and it set at a depth of $900 \mathrm{ft}$ bgs. The water level of WW-5b resides at approximately $680 \mathrm{ft}$ bgs. The third well, WW-5c, is an inactive well that was drilled to a depth of $1,200 \mathrm{ft}$ bgs. The well is located approximately 1.5 miles southwest of the CAS, where the approximate water level is $720 \mathrm{ft}$ bgs. (USGS, 2002)

\section{c. Type of Soil}

Corrective Action Site 05-99-05 lies near the center of Frenchman Flat, a hydrologically closed basin. The surface material in the basin is alluvium that consists mostly of silty to gravelly sand, with finer grained deposits (silt and clay) on the central playa. Recent drilling (NNSA/NSO, 2005) has indicated that in the center of the basin the alluvial materials are approximately 3,670 ft thick. The alluvium is underlain by approximately 4,000 ft of volcanic rocks, which in turn overlie the Paleozoic carbonate rocks that make up the regional carbonate aquifer.

\section{d. Annual Precipitation}

Frenchman Lake is located in one of the more arid regions of the country. While some ponding occurs on the dry lakebed during the rare heavy rain, according to data obtained from Weather Station 05, the average annual precipitation for Area 5 is 4-6 inches per year with the highest precipitation being 9.67 inches in 1998. This station has been monitored since 1963 .

\section{e. Type of Regulated Substance Released}

Based on technical and historical knowledge on the combat tank, it appears that the left fuel tank was punctured by munitions when the tank was used as a target in the Frenchman Lake location. While the right fuel tank was determined to be intact, it appears that the left fuel tank was punctured and a maximum of 133 gallons (maximum capacity) of diesel fuel may have been released to the ground directly below the vehicle. Based on the results of the field screening and verification samples a majority of the TPH-impacted soil was removed by excavation in December 2004. 


\section{f. Extent of Contamination}

Contamination from the diesel fuel release is estimated to have extended approximately $5 \mathrm{ft}$ horizontally to a maximum depth of $11 \mathrm{ft}$ bgs vertically. The majority of this soil was excavated in December 2004.

\section{g. Present and Potential Land Use}

The area is currently used as a storage area for discarded equipment. No facilities are operating in the immediate vicinity at present. The nearest facility is the Non-Proliferation Test and Evaluation Complex (formerly known as the Hazardous Material Spill Test Center) located approximately 2 miles to the west. Due to the proximity of the site to former nuclear weapons atmospheric testing sites, no development is likely.

\section{h. Preferred Routes of Migration (and Exposure Pathways of Concern)}

The only likely TPH-migration scenario at this location is through infiltrating precipitation. Based on the limited precipitation, the excavation of the majority of the impacted soil, and the removal of the source itself (the combat tank) from the site, migration of TPH is expected to be negligible. A utility survey indicated that no buried utilities are located in the area that may serve as pathways.

\section{i. Location of Structures or Impediments}

No below-grade structures are located in the vicinity of the site. A utility survey also indicated that no buried utilities are located in the area that may serve as a pathway.

\section{j. Potential for a Hazard Related to Fire, Vapor, or Explosion}

There is no potential for these hazards.

\section{k. Other factors Specific to the Site}

As discussed previously, the majority of the TPH-impacted soil was removed in December 2004 through excavation. Verification sampling indicated that the highest TPH concentration detected in the samples was $700 \mathrm{mg} / \mathrm{kg}$. In addition, the original source of the release (the combat tank itself) has been removed from the site.

Based on the evaluation of the "a through $k$ " criteria as presented above and the previously described BMP activities, no additional closure activities are warranted at this site. CAS 05-99-05 was closed by taking No Further Action.

\section{CAS 19-19-02: Trash Pits}

Verification of site closure consisted of performing a visual inspection of the site and documenting the current site conditions. The waste drums originally identified were no longer present. Debris at the site is within a potential crater area, preventing workers and equipment from removing it. 
THIS PAGE INTENTIONALLY LEFT BLANK 


\subsection{SUMMARY AND RECOMMENDATIONS}

\subsection{SUMMARY}

The following closure activities were completed at the two CASs in CAU 167:

\section{CAS 05-99-05, Combat Tank; Radioactive Material}

- Transferred ownership of the tank to the NCCT, and relocated the tank from the CAS to a controlled area in Area 1 of the NTS.

- Performed a radiological survey of the area and deposted the area as a RMA.

- Removed and disposed of surface debris including fence posts and a wooden pallet.

- Collected and analyzed soil waste classification samples from the site.

- Removed and disposed of approximately $40 \mathrm{yd}^{3}$ of petroleum hydrocarbon-impacted soil from beneath the former location of the tank.

- Collected and analyzed soil verification samples from the site excavation.

- Backfilled the excavation with clean fill and compacted the fill by wheel rolling with heavy equipment.

- Performed an "A through K" risk assessment to determine the risk to health and the environment posed by leaving low concentrations of hydrocarbons in soil in the shallow subsurface.

CAS 19-19-02, Trash Pit: Verified that waste originally identified was no longer present on site; documented current site conditions.

\subsection{RECOMMENDATIONS}

Because closure activities for CAU 167 have been completed following the NDEP-approved Sectored Clean-up Work Plan for Housekeeping Category Waste Sites (NNSA/NSO, 2003) as documented in this report, NNSA/NSO requests the following:

1. A "Notice of Completion" be provided by the NDEP to the NNSA/NSO for the closure of CAU 167.

2. The transfer of CAU 167 from Appendix III to Appendix IV of the FFACO Closed Corrective Action Units (FFACO, 1996). 
Closure Report - CAU 167

Section: Summary \& Recomm

Revision: 1

Date: April 2005

THIS PAGE INTENTIONALLY LEFT BLANK 
BN, see Bechtel Nevada.

Bechtel Nevada. 2003. Site-Specific Health and Safety Plan for Corrective Action Units 167, 210, 286, 390, \& 396 Housekeeping Sites, Nevada Test Site, Nevada, Rev. 1, Las Vegas, NV.

EPA, see U.S. Environmental Protection Agency.

FFACO, see Federal Facility Agreement and Consent Order.

Federal Facility Agreement and Consent Order. 1996 (as amended). Agreed to by the State of Nevada, U.S. Department of Energy, and U.S. Department of Defense.

NAC, see Nevada Administrative Code.

NDEP, see Nevada Division of Environmental Protection.

NNSA/NSO, see U.S. Department of Energy, National Nuclear Security Administration Nevada Site Office.

Nevada Administrative Code. 2002. 445A.227 "Contamination of Soil: Order by Director for Corrective Action; Factors to be Considered in Determining Whether Corrective Action is Required." Carson City, NV.

Nevada Administrative Code. 2003. NAC 445A.2272, "Contamination of Soil: Establishment of Action Levels". Carson City, NV.

Nevada Division of Environmental Protection. March 9, 2004. Letter to Janet Appenzeller-Wing. National Nuclear Security Administration Nevada Site Office. "Proposed Radiological Actions Levels for the Industrial Sites Project."

U.S. Department of Energy, Nevada Operations Office. 2000. United States Nuclear Tests, July 1945 through September 1992. DOE/NV--209 (Rev. 15). Las Vegas, NV.

U.S. Department of Energy, National Nuclear Security Administration, Nevada Site Office. 2003a. Generic Field Management Plan for Housekeeping Category Waste Sites, Las Vegas, NV.

U.S. Department of Energy, National Nuclear Security Administration, Nevada Site Office. 2003b. Sectored Clean-up Work Plan for Housekeeping Category Waste Sites, DOE/NV--579-REV-3. Las Vegas, NV. 


\section{REFERENCES (continued)}

U.S. Department of Energy, National Nuclear Security Administration Nevada Site Office. 2005. Completion Report for Well Cluster ER-5-4, DOE/NV/11718--998.

Las Vegas, NV.

U.S. Environmental Protection Agency. 1996. Test Methods for Evaluating Solid Waste, Physical/Chemical Methods, EPA Publication SW-846, Third Edition. Washington, D.C.

U.S. Environmental Protection Agency. 2002. Region IX Preliminary Remediation Goals (PRGs), San Francisco, CA.

U.S. Geological Survey. 2002. "USGS/DOE Nevada Well WW-5a and WW-5c WW Site Page," as accessed at http://nevada.usgs.gov/doe_nv/ntsarea5.cfm on January 24, 2005. 


\section{APPENDIX A}

\section{SAMPLE ANALYTICAL RESULTS}


Closure Report - CAU 167

Section: Appendix A

Revision: 1

Date: April 2005

THIS PAGE INTENTIONALLY LEFT BLANK 


\section{Appendix A. Sample Analytical Results By Sample Delivery Group}

Analytical results for the samples collected at the indicated Corrective Action Site (CAS) for Corrective Action Unit 167 are presented in this Appendix. The analytical results are grouped by Sample Delivery Group(s), which are arranged in numerical order in this Appendix. Analytical results for the specific CAS can be found by consulting the indicated Sample Delivery Groups.

\begin{tabular}{lll} 
CAS & Sample Delivery Groups & Analysis \\
\hline $05-99-05$ & V2126 & TPH, RCRA Metals, VOCs, SVOCs, PCBs \\
V2127 & Gamma emitters \\
V2162 & TPH \\
V2332 & TPH, PCBs \\
& V2376 & TPH
\end{tabular}


Closure Report - CAU 167

Section: Appendix A

Revision: 1

Date: April 2005

\section{THIS PAGE INTENTIONALLY LEFT BLANK}


Closure Report - CAU 167

Section: Appendix A

Revision: I

Date: April 2005

\section{SAMPle Delivery GrouP}

V2126 
Closure Report - CAU 167

Section: Appendix A

Revision: 1

Date: April 2005

THIS PAGE INTENTIONALLY LEFT BLANK 


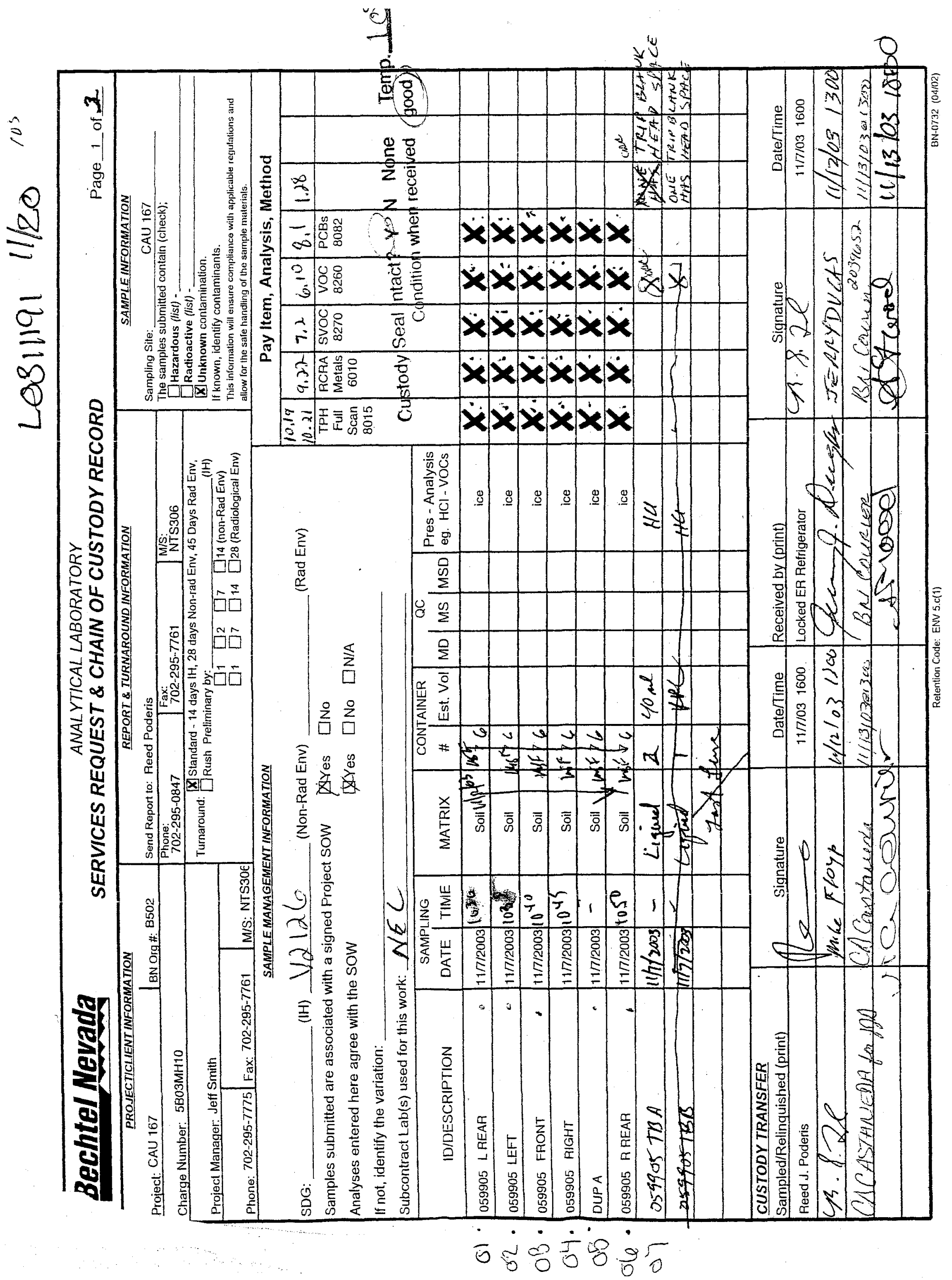


THIS PAGE INTENTIONALLY Y LEFT BLANK 
NEL Laboratories, Las Vegas

Date: 26-Nov-03

$\begin{array}{lll}\text { CLIENT: } & \text { Bechtel Nevada } & \text { Client Sample ID: } 059905 \text { L. Rear } \\ \text { Lab Order: } & \text { L0311191 } & \text { Collection Date: 11/7/03 10:30:00 AM }\end{array}$

Project: V2126

Lab ID: $\quad$ L0311191-001

Matrix: SOLID

\begin{tabular}{|c|c|c|c|c|c|}
\hline Analyses & Result & Limit & Qual Units & DF & Date Analyzed \\
\hline TOTAL EXTRACTABLE TPH & \multicolumn{3}{|c|}{ SW8015M } & \multicolumn{2}{|r|}{ Analyst: FAS-L } \\
\hline Gasoline Range Organics (C8-C12) & ND & 20 & $\mathrm{mg} / \mathrm{kg}$ & 1 & $11 / 20 / 03$ \\
\hline Diesel Range Organics ( $\mathrm{C} 12-\mathrm{C} 22)$ & ND & 20 & $\mathrm{mg} / \mathrm{Kg}$ & 1 & $11 / 20 / 03$ \\
\hline Oil Range Organics (C22-C34) & 80 & 50 & $\mathrm{mg} / \mathrm{Kg}$ & 1 & $11 / 20 / 03$ \\
\hline Total Petroleum Hydrocarbons & 80 & 20 & $\mathrm{mg} / \mathrm{Kg}$ & 1 & $11 / 20 / 03$ \\
\hline Surr: n-Octacosane & 73.1 & $34.8-139$ & $\%$ REC & 1 & $11 / 20 / 03$ \\
\hline POLYCHORINATED BIPHENYLS & \multicolumn{2}{|c|}{ SW8082 } & & \multicolumn{2}{|r|}{ Analyst: JRW-L } \\
\hline Aroclor 1016 & ND & 20 & $\mu g / \mathrm{Kg}$ & 1 & $11 / 20 / 03$ \\
\hline Aroclor 1221 & ND & 20 & $\mu \mathrm{g} / \mathrm{Kg}$ & 1 & $11 / 20 / 03$ \\
\hline Aroclor 1232 & ND & 20 & $\mu g / K g$ & 1 & $11 / 20 / 03$ \\
\hline Aroclor 1242 & ND & 20 & $\mu g / \mathrm{Kg}$ & 1 & $1 \cdot 1 / 20 / 03$ \\
\hline Aroclor 1248 & ND & 20 & $\mu g / \mathrm{Kg}$ & 1 & $11 / 20 / 03$ \\
\hline Aroclor 1254 & ND & 20 & $\mu g / K g$ & 1 & $11 / 20 / 03$ \\
\hline Aroclor 1260 & ND & 20 & $\mu g / \mathrm{Kg}$ & 1 & $11 / 20 / 03$ \\
\hline Surr: Tetrachloro-m-xylene & 104 & $36.2-139$ & $\%$ REC & 1 & $11 / 20 / 03$ \\
\hline Surr: Decachlorobiphenyl & 88.0 & $34.8-132$ & $\%$ REC & 1 & $11 / 20 / 03$ \\
\hline ICP METALS, TOTAL & \multicolumn{3}{|c|}{ SW6010B } & \multicolumn{2}{|r|}{ Analyst: WVG-L } \\
\hline Arsenic & 7.8 & 5.1 & $\mathrm{mg} / \mathrm{Kg}$ & 1 & 11/19/03 1:35:00 PM \\
\hline Barium & 130 & 0.26 & $\mathrm{mg} / \mathrm{kg}$, & 1 & 11/19/03 1:35:00 PM \\
\hline Cadmium & 0.84 & 0.26 & $\mathrm{mg} / \mathrm{Kg}$ & 1 & 11/19/03 1:35:00 PM \\
\hline Chromium & 10 & 0.51 & $\mathrm{mg} / \mathrm{Kg}$ & 1 & 11/19/03 1:35:00 PM \\
\hline Lead & 13 & 0.26 & $\mathrm{mg} / \mathrm{Kg}$ & 1 & 11/19/03 1:35:00 PM \\
\hline Selenium & ND & 5.1 & $\mathrm{mg} / \mathrm{kg}$ & 1 & 11/19/03 1:35:00 PM \\
\hline Silver & ND & 0.51 & $\mathrm{mg} / \mathrm{Kg}$ & 1 & 11/19/03 1:35:00 PM \\
\hline MERCURY, TOTAL & & V7471 & & & Analyst: ATV-L \\
\hline Mercury & 0.14 & 0.031 & $\mathrm{mg} / \mathrm{Kg}$ & 1 & $11 / 14 / 03$ \\
\hline SEMIVOLATILE ORGANICS & & v8270C & & & Analyst: JRW-L \\
\hline 1,2,4-Trichlorobenzene & ND & . $\quad 330$ & $\mu g / \mathrm{Kg}$ & 1 & $11 / 19 / 03$ \\
\hline 1,2-Dichlorobenzene & ND & 330 & $\mu g / K g$ & 1 & $11 / 19 / 03$ \\
\hline 1,3-Dichlorobenzene & ND & 330 & $\mu g / K g$ & 1 & $11 / 19 / 03$ \\
\hline 1,4-Dichlorobenzene & ND & 330 & $\mu g / \mathrm{Kg}$ & 1 & $11 / 19 / 03$ \\
\hline $2,4,5$-Trichlorophenol & ND & 330 & $\mu g / K g$ & 1 & $11 / 19 / 03$ \\
\hline 2,4,6-Trichlorophenol & ND & 330 & $\mu g / \mathrm{Kg}$ & 1 & $11 / 19 / 03$ \\
\hline 2,4-Dichlorophenol & ND & 330 & $\mu g / K g$ & 1 & $11 / 19 / 03$ \\
\hline 2,4-Dimethylphenol & ND & 330 & $\mu g / \mathrm{Kg}$ & 1 & 11/19/03 \\
\hline 2,4-Dinitrophenol & ND & 330 & $\mu g / \mathrm{Kg}$ & 1 & $11 / 19 / 03$ \\
\hline 2,4-Dinitrotoluene & ND & 330 & $\mu \mathrm{g} / \mathrm{Kg}$ & 1 & $11 / 19 / 03$ \\
\hline 2,6-Dinitrotoluene & ND & 330 & $\mu g / \mathrm{Kg}$ & 1 & $11 / 19 / 03$ \\
\hline 2-Chloronaphthalene & ND & 330 & $\mu g / \mathrm{Kg}$ & 1 & $11 / 19 / 03$ \\
\hline 2-Chiorophenol & ND & 330 & $\mu \mathrm{g} / \mathrm{Kg}$ & 1 & $11 / 19 / 03$ \\
\hline ND - Not Detected at t & Ig Limit & & S - Spike R & tside ac & ed recovery limits \\
\hline J-Analyte detected be & itation limit & & $R-R P D$ ou & ted reco & limits \\
\hline B - Analyte detected in & ated Metho & Blank & E - Value a & itation $\mathrm{r}$ & \\
\hline
\end{tabular}

* - Value exceeds Maximum Contaminant Level 
NEL Laboratories, Las Vegas

Date: 26-Nov-03

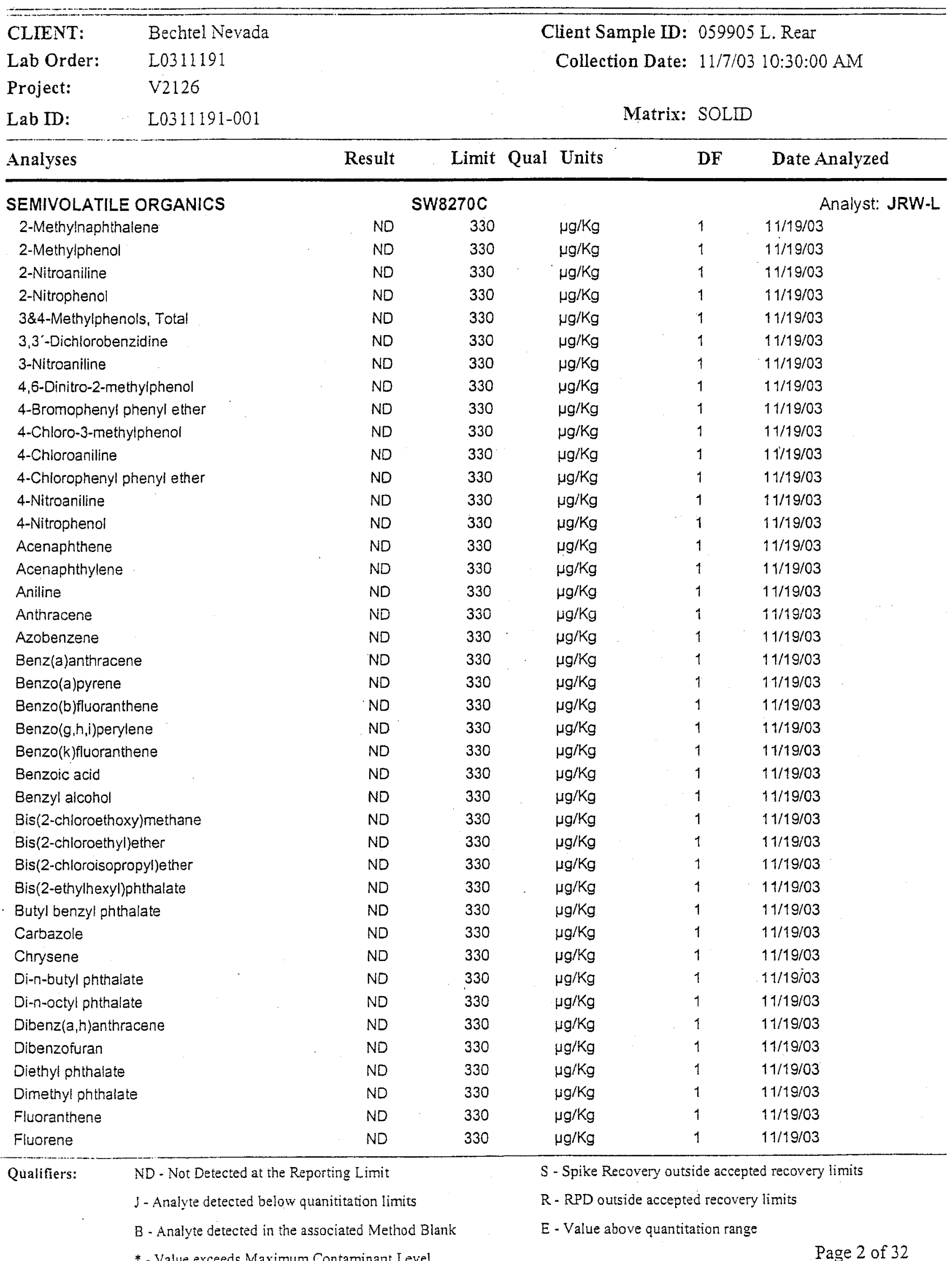


NEL Laboratories, Las Vegas

Date: 26-Nov-03

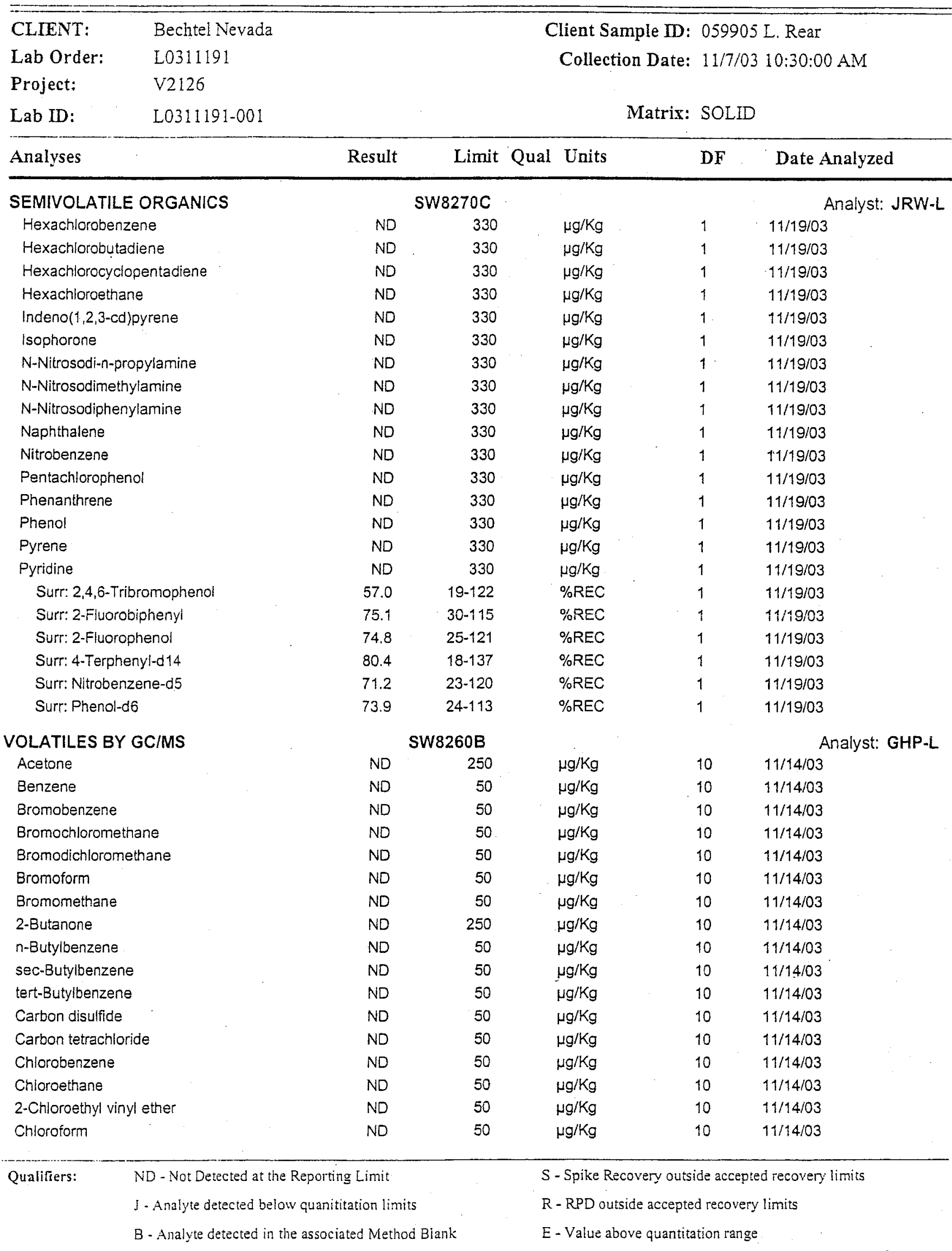

* - Value exceeds Maximum Contaminant Level 
NEL Laboratories, Las Vegas

Date: 26-Nov-03

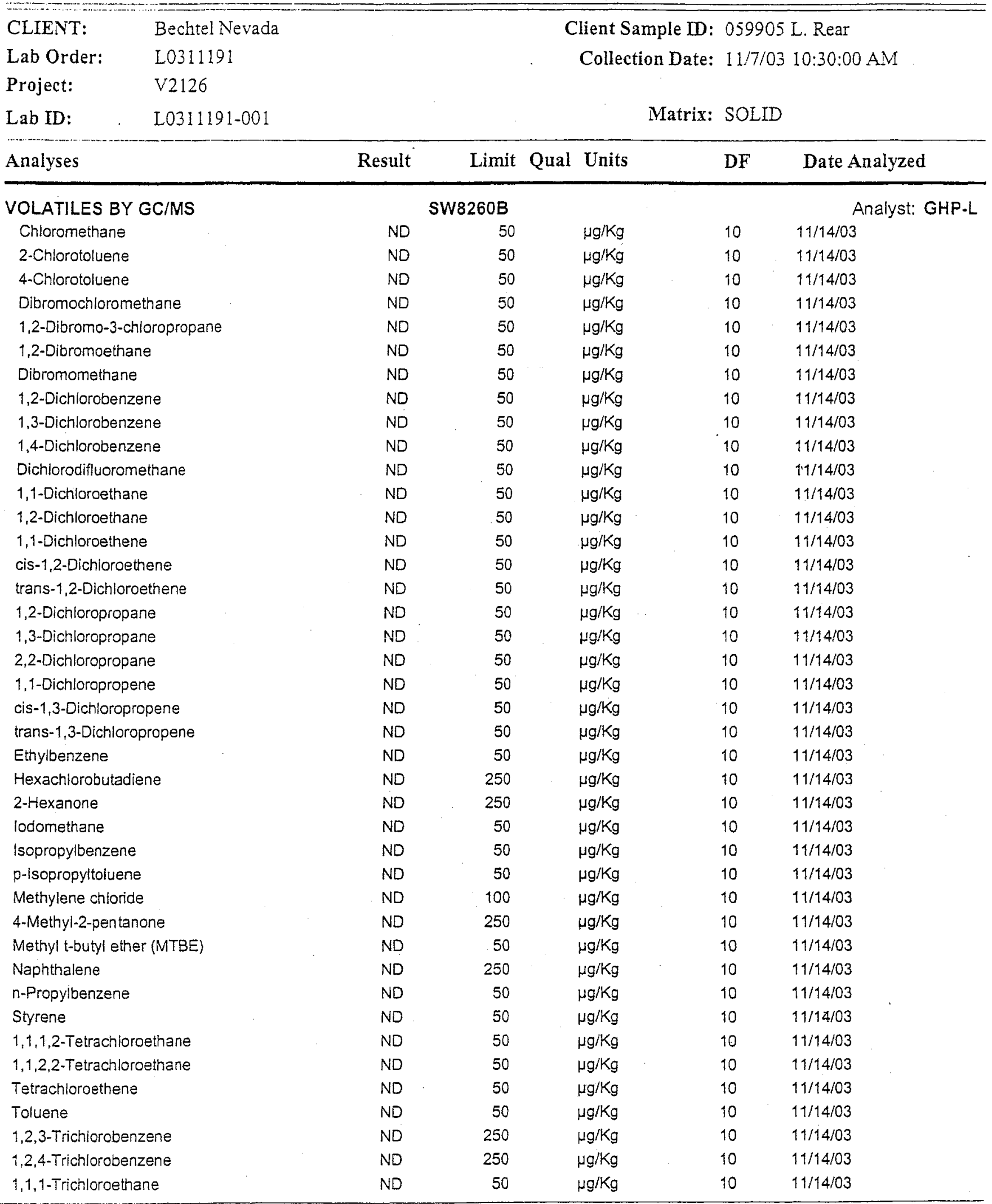

Qualifiers: ND-Not Detected at the Reporting Limit

S - Spike Recovery outside accepted recovery limits

I - Analyte detected below quanititation limits

$R$ - RPD outside accepted recovery limits

B - Analyte detected in the associated Method Blank

E - Value above quantitation range

* - Value exceeds Maximum Contaminant Level 
NEL Laboratories, Las Vegas

Date: 26-Nov-03

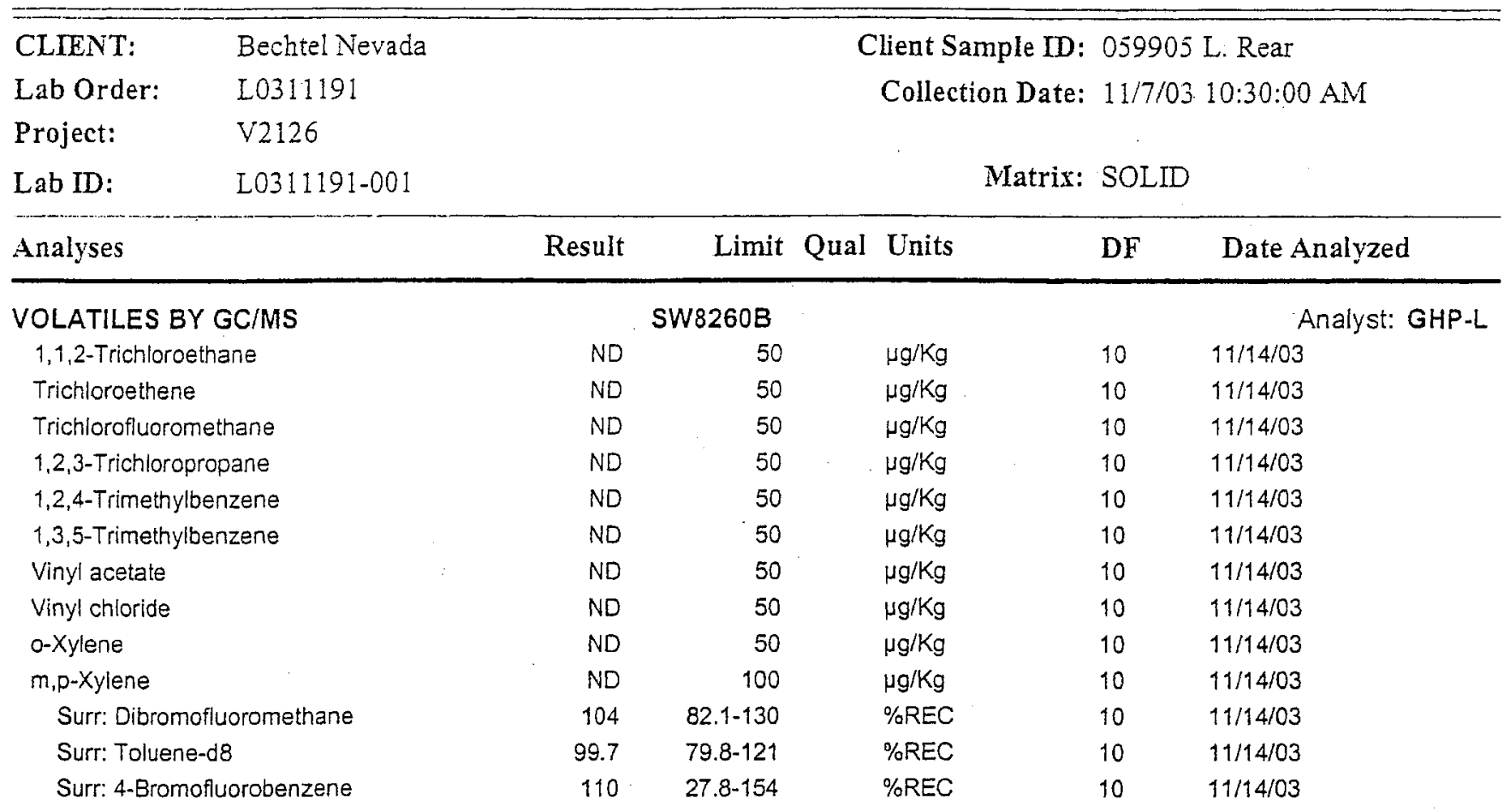

\begin{tabular}{lll}
\hline Qualifiers: & ND - Not Detected at the Reporting Limit & S - Spike Recovery outside accepted recovery limits \\
& $j$-Analyte detected below quanititation limits & R - RPD outside accepted recovery limits \\
B - Analyte detected in the associated Method Blank & E - Value above quantitation range
\end{tabular}

* Value exceeds Maximum Contaminant Level 


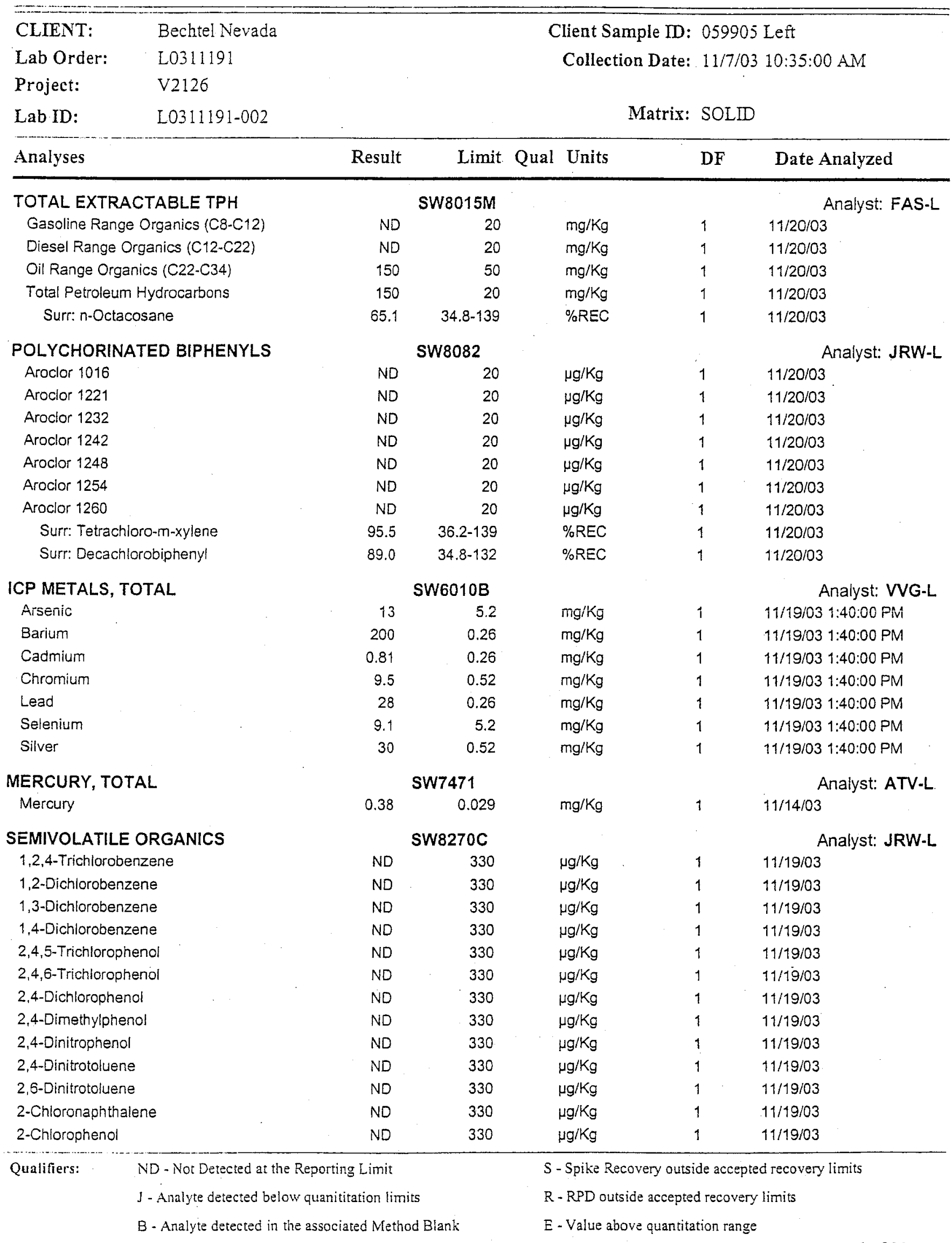

* - Value exceeds Maximum Contaminant Level 
NEL Laboratories, Las Vegas

Date: 26-Nov-03

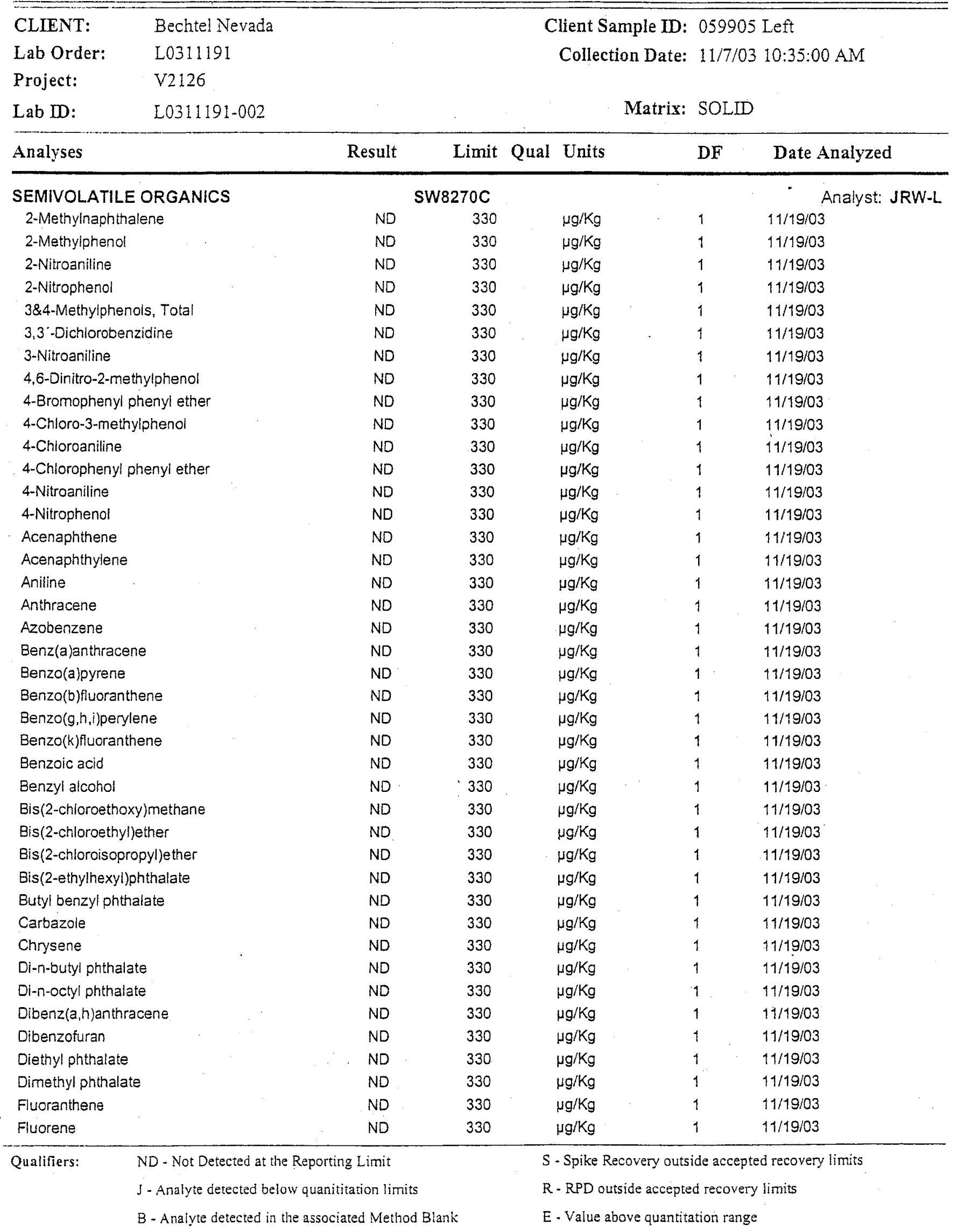

* Value exceeds Maximum Contaminant Level 
NEL Laboratories, Las Vegas

Date: 26-Nov-03

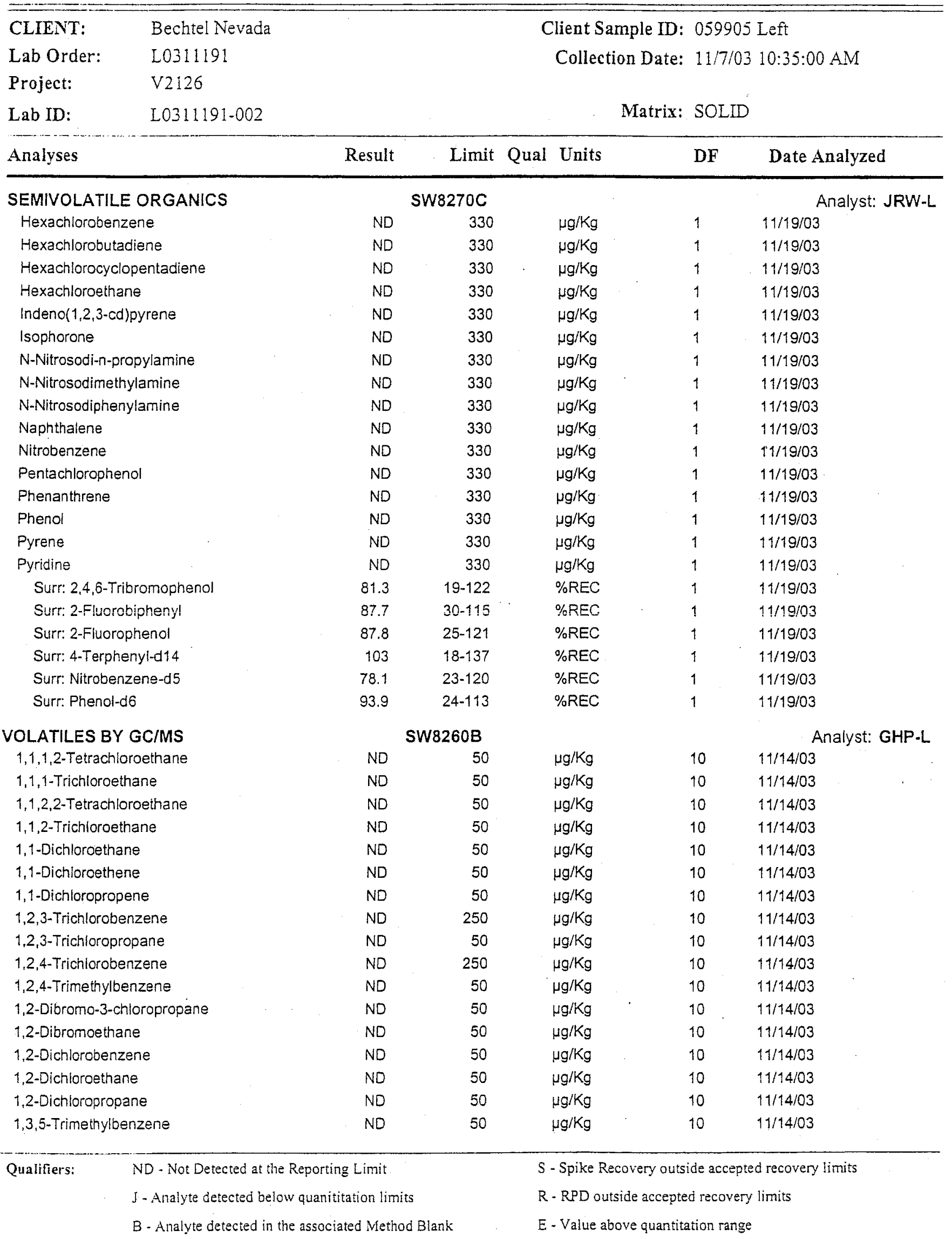

* Value exceeds Maximum Contaminant Level 
NEL Laboratories, Las Vegas

Date: $26-\mathrm{Nov}-03$

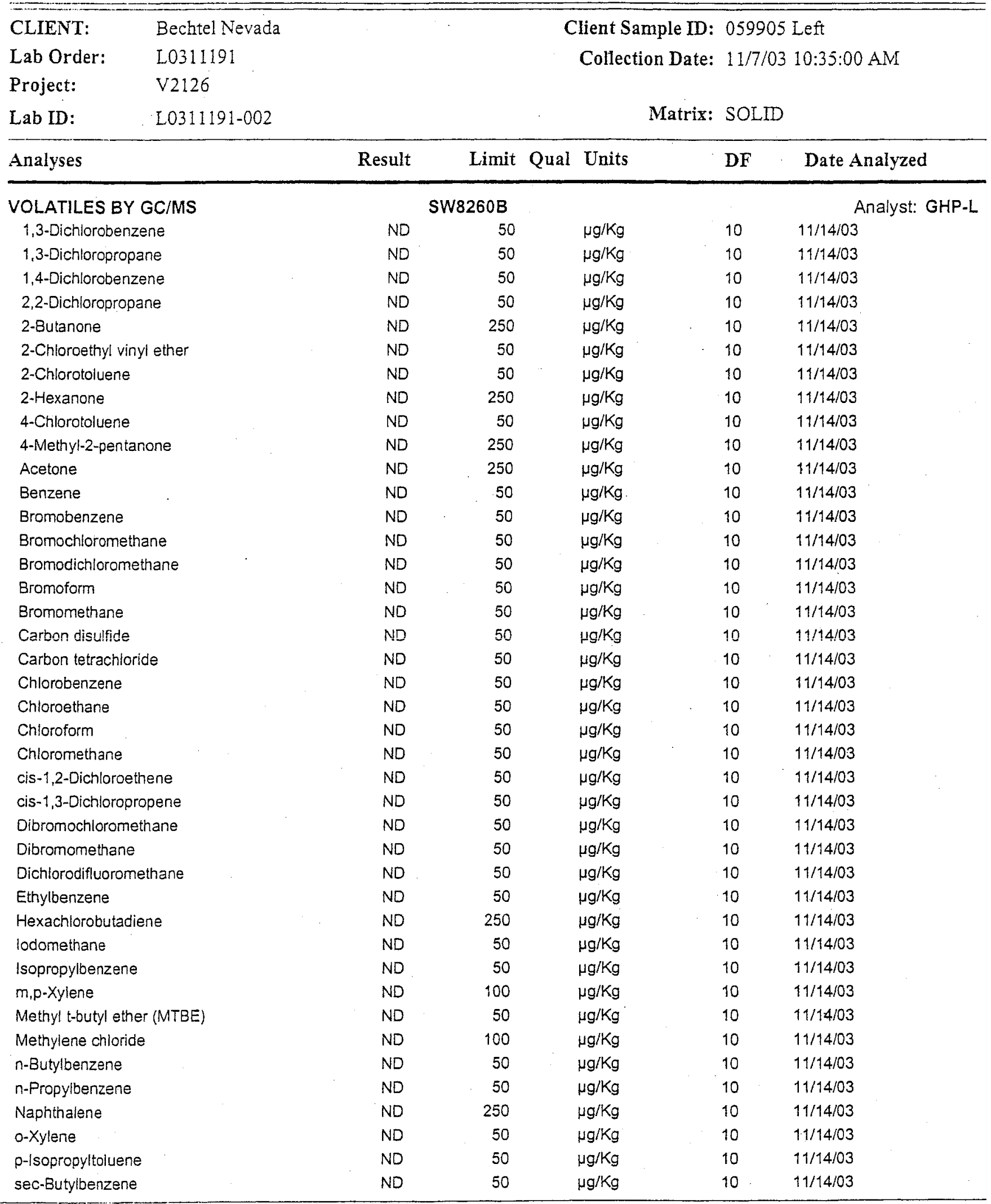

Qualifiers: ND - Not Detected at the Reporting Limit

$S$ - Spike Recovery outside accepted recovery limits

J - Analyte detected below quanititation limits

R - RPD outside accepted recovery limits

B - Analyte detected in the associated Method Blank

E-Value above quantitation range

* - Value exceeds Maximum Contaminant Level 
NEL Laboratories, Las Vegas

Date: 26-Nov-03

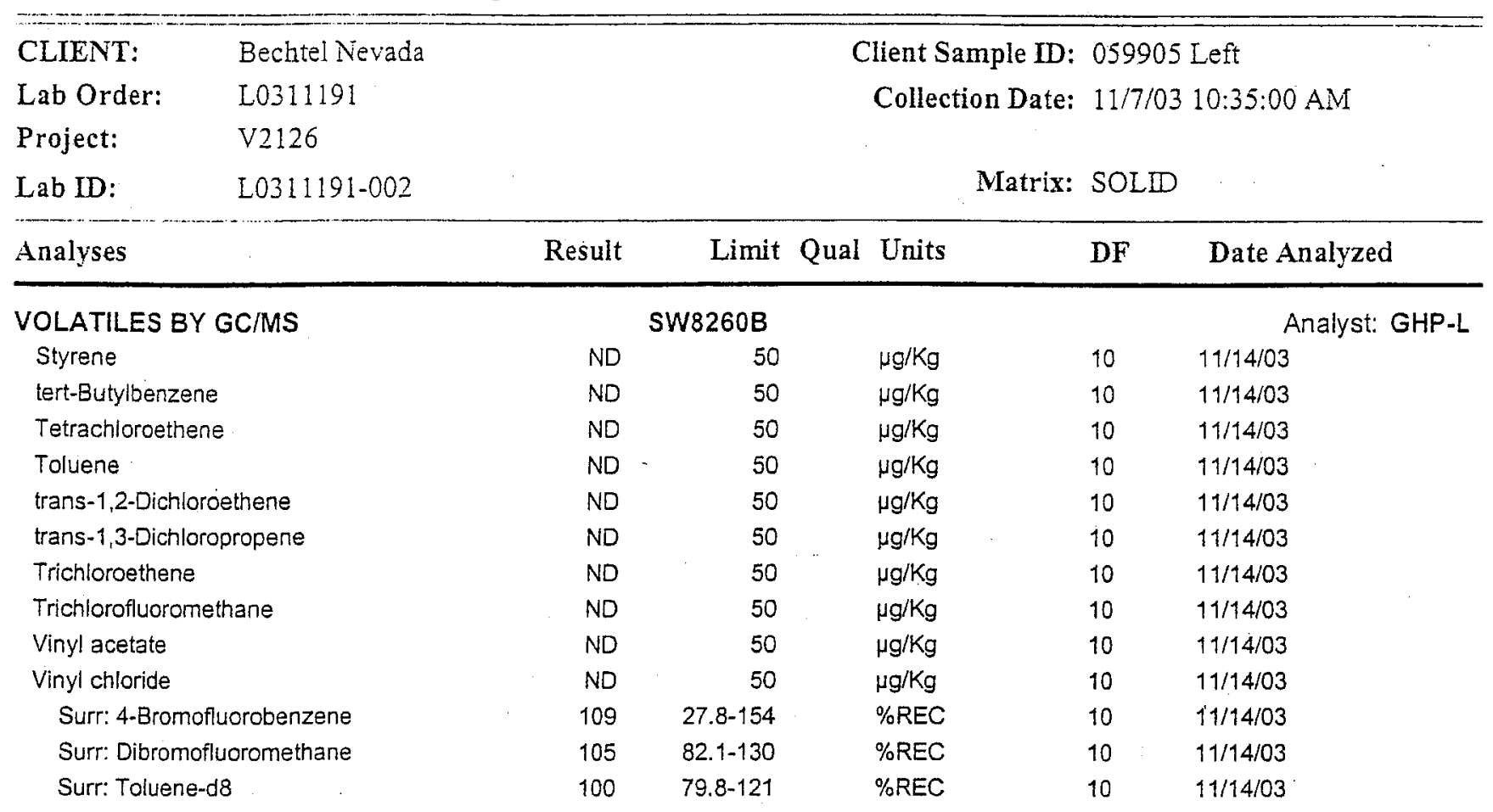

$\begin{array}{ll}\text { Qualifiers: } & \text { ND - Not Detected at the Reporting Limit } \\ \text { J - Analyte detected below quanititation limits } & \text { R - RPD outside accepted recovery limits } \\ \text { B - Analyte detected in the associated Method Blank } & \text { E - Value above quantitation range }\end{array}$

* - Value exceeds Maximum Contaninant Level 


$\begin{array}{llr}\text { CLIENT: } & \text { Bechtel Nevada } & \text { Client Sample ID: } 059905 \text { Front } \\ \text { Lab Order: } & \text { L0311191 } & \text { Collection Date: } 11 / 7 / 03 \text { 10:40:00 AM } \\ \text { Project: } & \text { V2126 } & \end{array}$

Lab ID: $\quad$ L0311191-003

Matrix: SOLID

\begin{tabular}{|c|c|c|c|c|c|}
\hline Analyses & Result & Limit & Qual Units & $\mathrm{DF}$ & Date Analyzed \\
\hline TOTAL EXTRACTABBLE TPH & \multicolumn{3}{|c|}{ SW8015M } & \multicolumn{2}{|r|}{ Analyst: FAS $\mathrm{L}$} \\
\hline Gasoline Range Organics (C8-C12) & ND & 20 & $\mathrm{mg} / \mathrm{Kg}$ & 1 & $11 / 20 / 03$ \\
\hline Diesel Range Organics (C12-C22) & ND & 20 & $\mathrm{mg} / \mathrm{Kg}$ & 1 & $11 / 20 / 03$ \\
\hline Oil Range Organics (C22-C34) & 58 & 50 & $\mathrm{mg} / \mathrm{Kg}$ & 1 & $11 / 20 / 03$ \\
\hline Total Petroleum Hydrocarbons & 58 & 20 & $\mathrm{mg} / \mathrm{Kg}$ & 1 & $11 / 20 / 03$ \\
\hline Surr: n-Octacosane & 76.1 & $34.8-139$ & $\% R E C$ & 1 & $11 / 20 / 03$ \\
\hline POLYCHORINATED BIPHENYLS & \multicolumn{3}{|c|}{ sW8082 } & \multicolumn{2}{|r|}{ Analyst: JRW-L } \\
\hline Aroclor 1016 & ND & 20 & $\mu g / \mathrm{Kg}$ & 1 & $11 / 20 / 03$ \\
\hline Aroclor 1221 & ND & 20 & $\mu g / K g$ & 1 & $11 / 20 / 03$ \\
\hline Arocior 1232 & ND & 20 & $\mu g / \mathrm{Kg}$ & 1 & $11 / 20 / 03$ \\
\hline Aroclor 1242 & ND & 20 & $\mu g / \mathrm{Kg}$ & 1 & $\$ 1 / 20 / 03$ \\
\hline Aroclor 1248 & ND & 20 & $\mu g / K g$ & 1 & $11 / 20 / 03$ \\
\hline Aroclor 1254 & ND & 20 & $\mu \mathrm{g} / \mathrm{Kg}$ & 1 & $11 / 20 / 03$ \\
\hline Aroclor 1260 & ND & 20 & $\mu g / \mathrm{Kg}$ & 1 & $11 / 20 / 03$ \\
\hline Surr: Tetrachloro-m-xylene & 139 & $36.2-139$ & $\%$ REC & 1 & $11 / 20 / 03$ \\
\hline Surr: Decachlorobiphenyl & 131 & $34.8-132$ & $\%$ REC & 1 & $11 / 20 / 03$ \\
\hline ICP METALS, TOTAL & \multicolumn{3}{|c|}{ SW6010B } & \multicolumn{2}{|r|}{ Analyst: VVG-L } \\
\hline Arsenic & 13 & 5.2 & $\mathrm{mg} / \mathrm{Kg}$ & 1 & 11/19/03 1:44:00 PM \\
\hline Barium & 110 & 0.26 & $\mathrm{mg} / \mathrm{Kg}$ & 1 & 11/19/03 1:44:00 PM \\
\hline Cadmium & 1.8 & 0.26 & $\mathrm{mg} / \mathrm{Kg}$ & 1 & $11 / 19 / 03$ 1:44:00 PM \\
\hline Chromium & 15 & 0.52 & $\mathrm{mg} / \mathrm{Kg}$ & 1 & $11 / 19 / 03$ 1:44:00 PM \\
\hline Lead & 46 & 0.26 & $\mathrm{mg} / \mathrm{Kg}$ & 1 & 11/19/03 1:44:00 PM \\
\hline Selenium & 6.2 & 5.2 & $\mathrm{mg} / \mathrm{Kg}$ & 1 & 11/19/03 1:44:00 PM \\
\hline Silver & ND & 0.52 & $\mathrm{mg} / \mathrm{Kg}$ & 1 & 11/19/03 1:44:00 PM \\
\hline MERCURY, TOTAL & & 17471 & & & Analyst: ATV-L \\
\hline Mercury & 0.36 & 0.030 & $\mathrm{mg} / \mathrm{Kg}$ & 1 & $11 / 14 / 03$ \\
\hline SEMIVOLATILE ORGANICS & & $18270 \mathrm{C}$ & & & Analyst: JRW-L \\
\hline 1,2,4-Trichlorobenzene & ND & 330 & $\mu g / \mathrm{Kg}$ & 1 & $11 / 19 / 03$ \\
\hline 1,2-Dichlorobenzene & ND & 330 & $\mu g / \mathrm{Kg}$ & 1 & $11 / 19 / 03$ \\
\hline 1,3-Dichlorobenzene & ND & 330 & $\mu \mathrm{g} / \mathrm{Kg}$ & 1 & $11 / 19 / 03$ \\
\hline 1.4-Dichlorobenzene & ND & 330 & $\mu g / \mathrm{Kg}$ & 1 & $11 / 19 / 03$ \\
\hline 2,4,5-Trichlorophenol & ND & 330 & $\mu g / \mathrm{Kg}$ & 1 & $11 / 19 / 03$ \\
\hline 2,4,6-Trichlorophenol & ND & 330 & $\mu \mathrm{g} / \mathrm{Kg}$ & 1 & $11 / 19 / 03$ \\
\hline 2,4-Dichlorophenol & ND & 330 & $\mu g / \mathrm{Kg}$ & 1 & $11 / 19 / 03$ \\
\hline 2,4-Dimethylphenol & ND & 330 & $\mu \mathrm{g} / \mathrm{Kg}$ & 1 & $11 / 19 / 03$ \\
\hline 2,4-Dinitrophenol & ND & 330 & $\mu g / \mathrm{Kg}$ & 1 & $11 / 19 / 03$ \\
\hline 2,4-Dinitrotoluene & ND & 330 & $\mu g / K g$ & 1 & $11 / 19 / 03$ \\
\hline 2,6-Dinitrotoluene & ND & 330 & $\mu g / K g$ & 1 & $11 / 19 / 03$ \\
\hline 2-Chloronaphthalene & ND & 330 & $\mu g / \mathrm{Kg}$ & 1 & $11 / 19 / 03$ \\
\hline 2-Chlorophenol & ND & 330 & $\mu \mathrm{g} / \mathrm{Kg}$ & 1 & $11 / 19 / 03$ \\
\hline ND - Not Detected at $t$ & ng Limit & & S-Spike Re & side acc & d recovery limits \\
\hline$J$ - Analyte detected be & titation $\lim$ & & $R-R P D$ out & ted reco & limits \\
\hline B - Analyte detected in & iated Metho & lank & E-Value $a b$ & tation ra & Page 11 of 32 \\
\hline
\end{tabular}


NEL Laboratories, Las Vegas

Date: 26-Nov-03

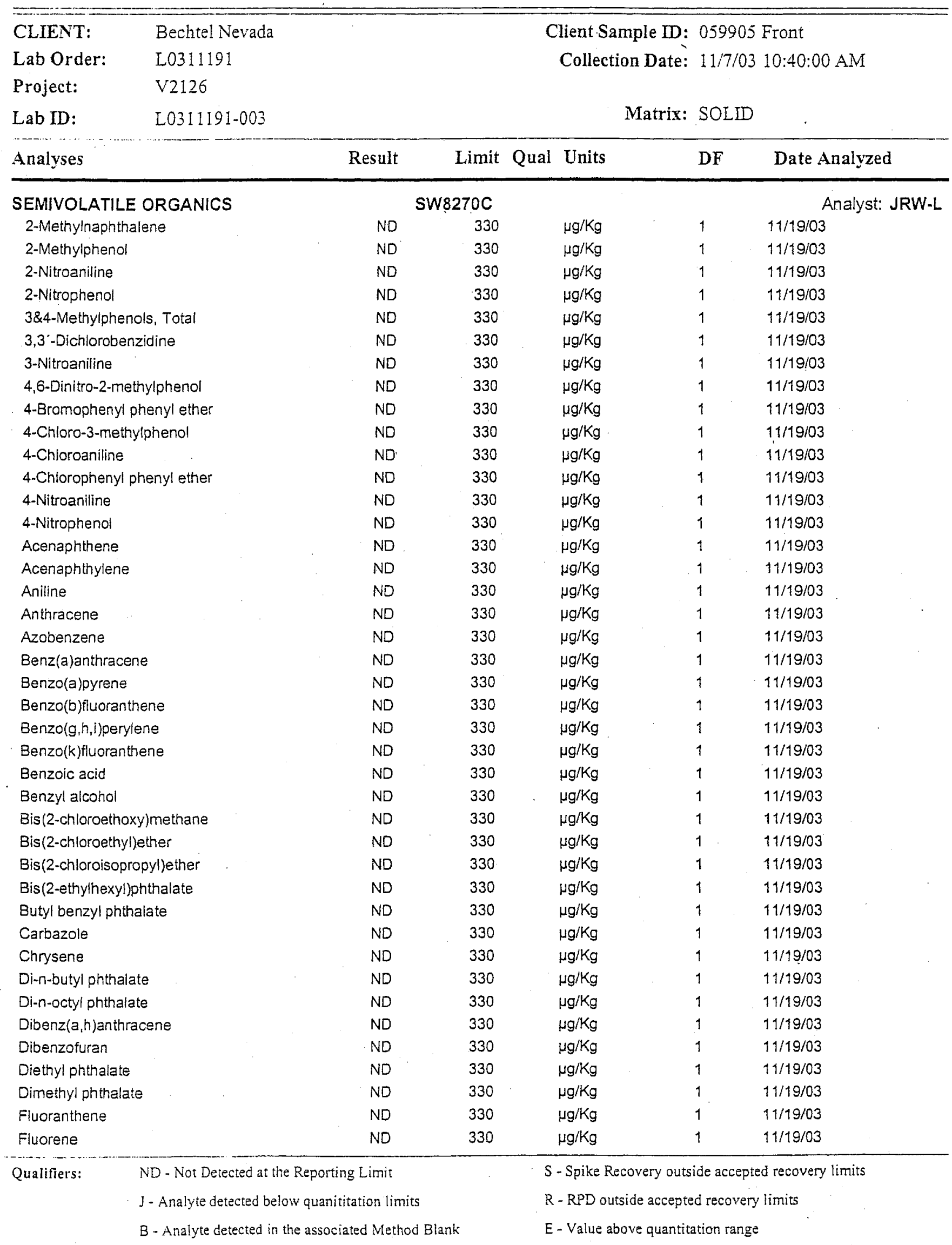

* - Value exceeds Maximum Contaminant Level 
NEL Laboratories, Las Vegas

Date: 26-Nov-03

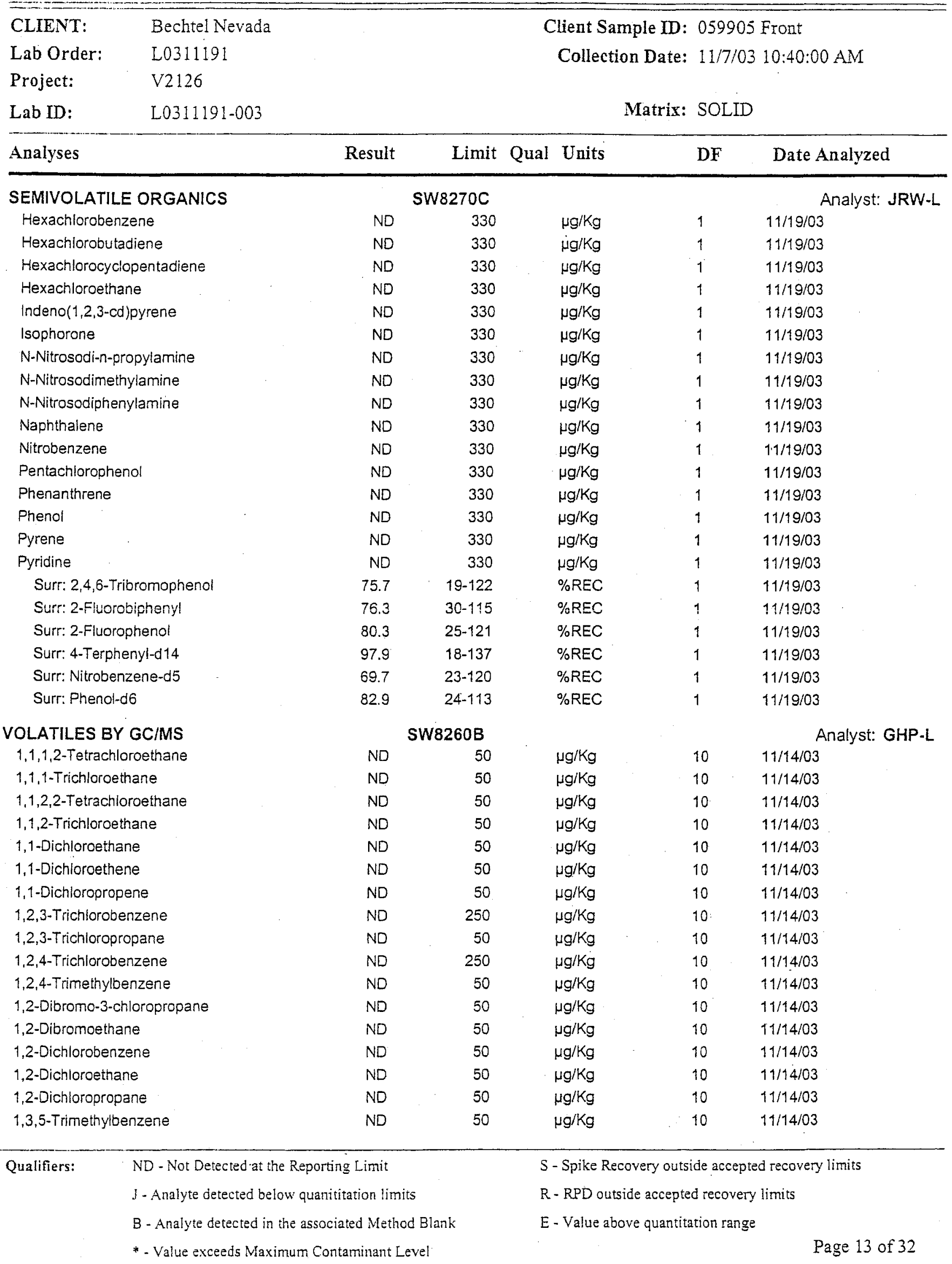


NEL Laboratories, Las Vegas

Date: 26-Nov-03

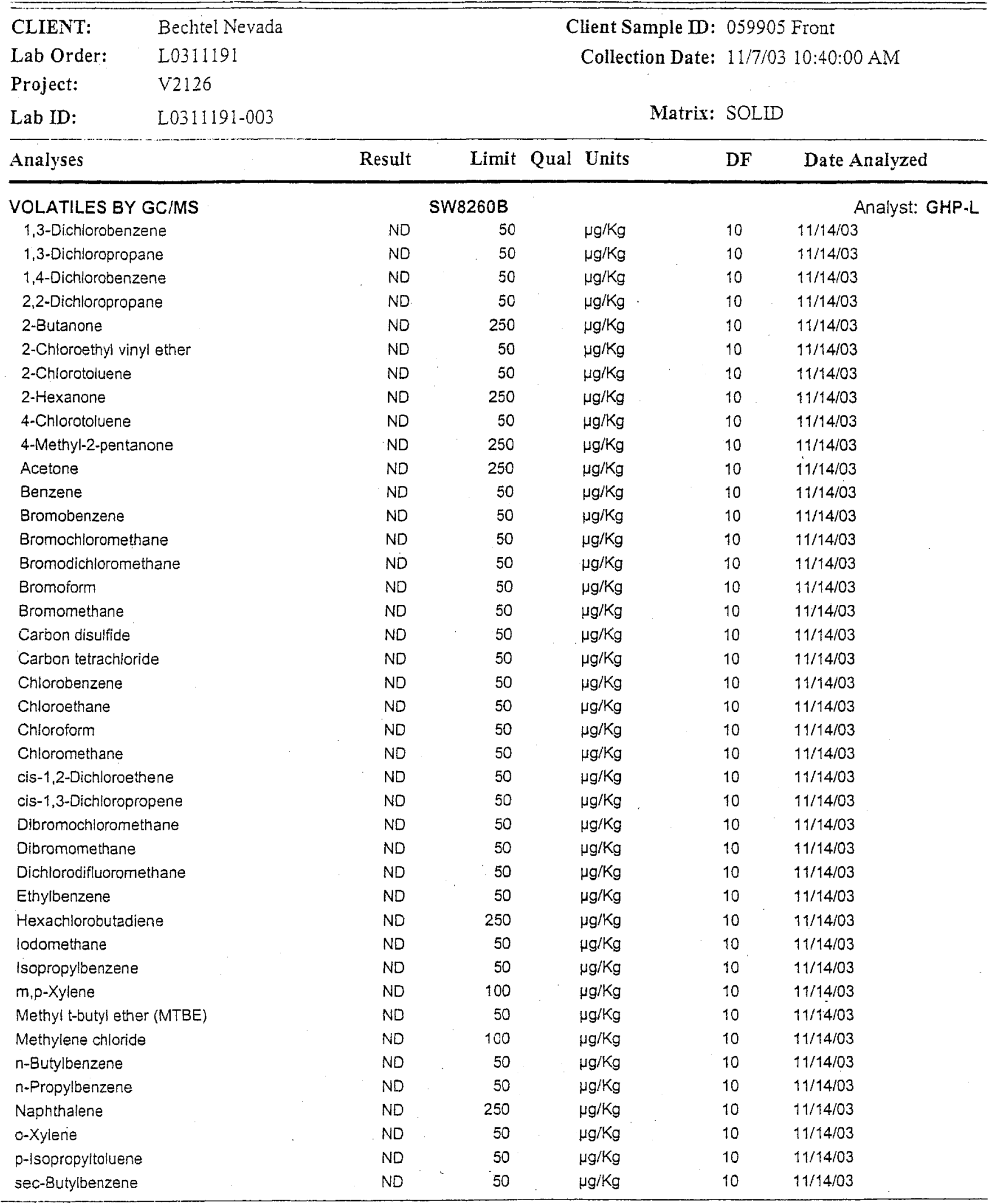

Qualifiers: ND - Not Detected at the Reporting Limit

$S$ - Spike Recovery outside accepted recovery limits

$J$ - Analyte detected below quanititation limits

$R$ - RPD outside accepted recovery limits

B - Analyte detected in the associated Method Blank

E - Value above quantitation range

* - Value exceeds Maximum Contaminant Level 
NEL Laboratories, Las Vegas

Date: 26-Nov-03

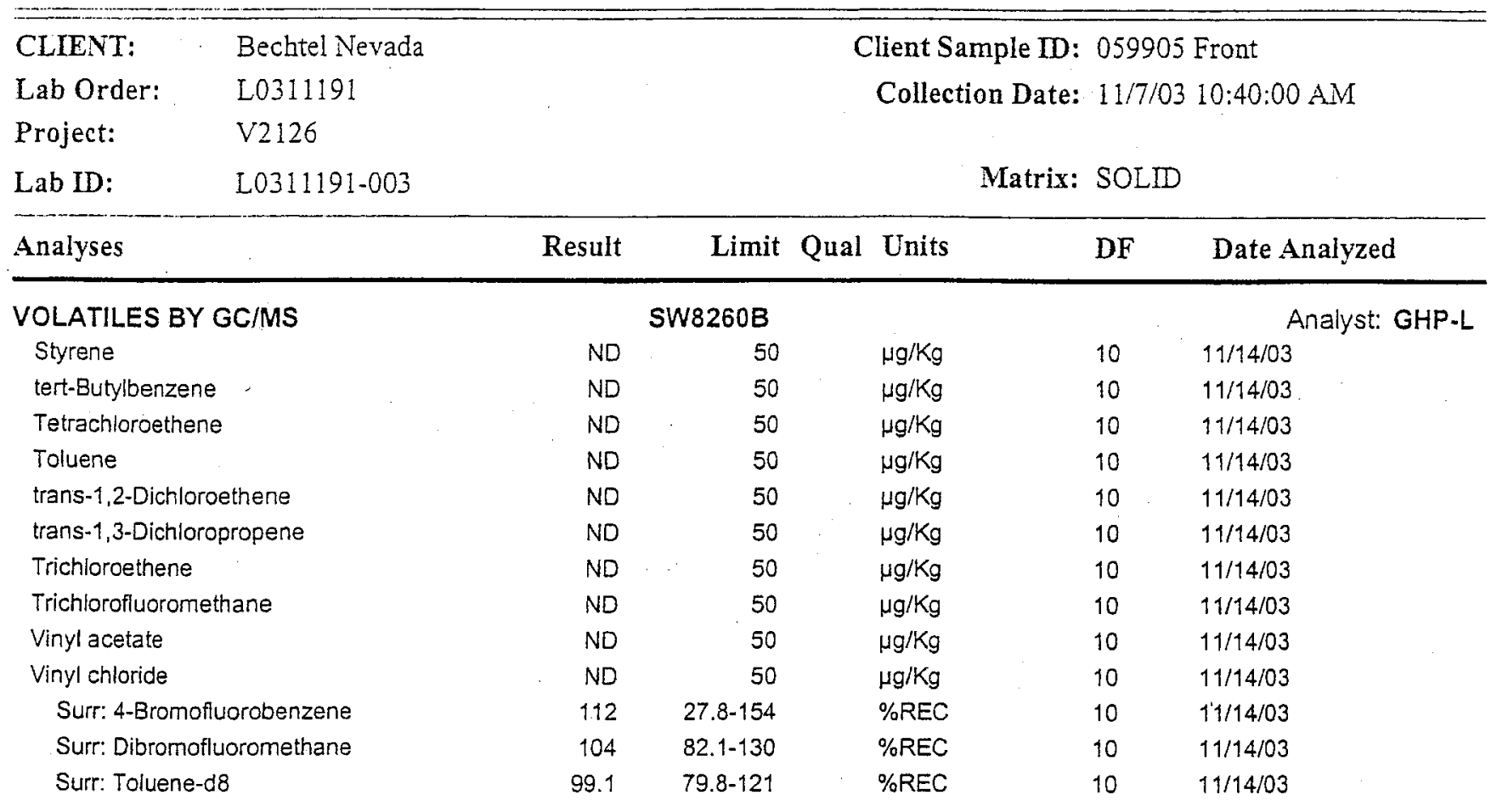

Qualifiers: ND-Not Detected at the Reporting Limit

J-Analyte derected below quaniritation limits

B - Analyte detected in the associated Method Blank

* - Value exceeds Maximum Contaminant Level
S - Spike Recovery outside accepted recovery limits

R - RPD outside accepted tecovery limits

E - Value above quantitation range

Page 15 of 32 
NEL Laboratories, Las Vegas

Date: 26-Nov-03

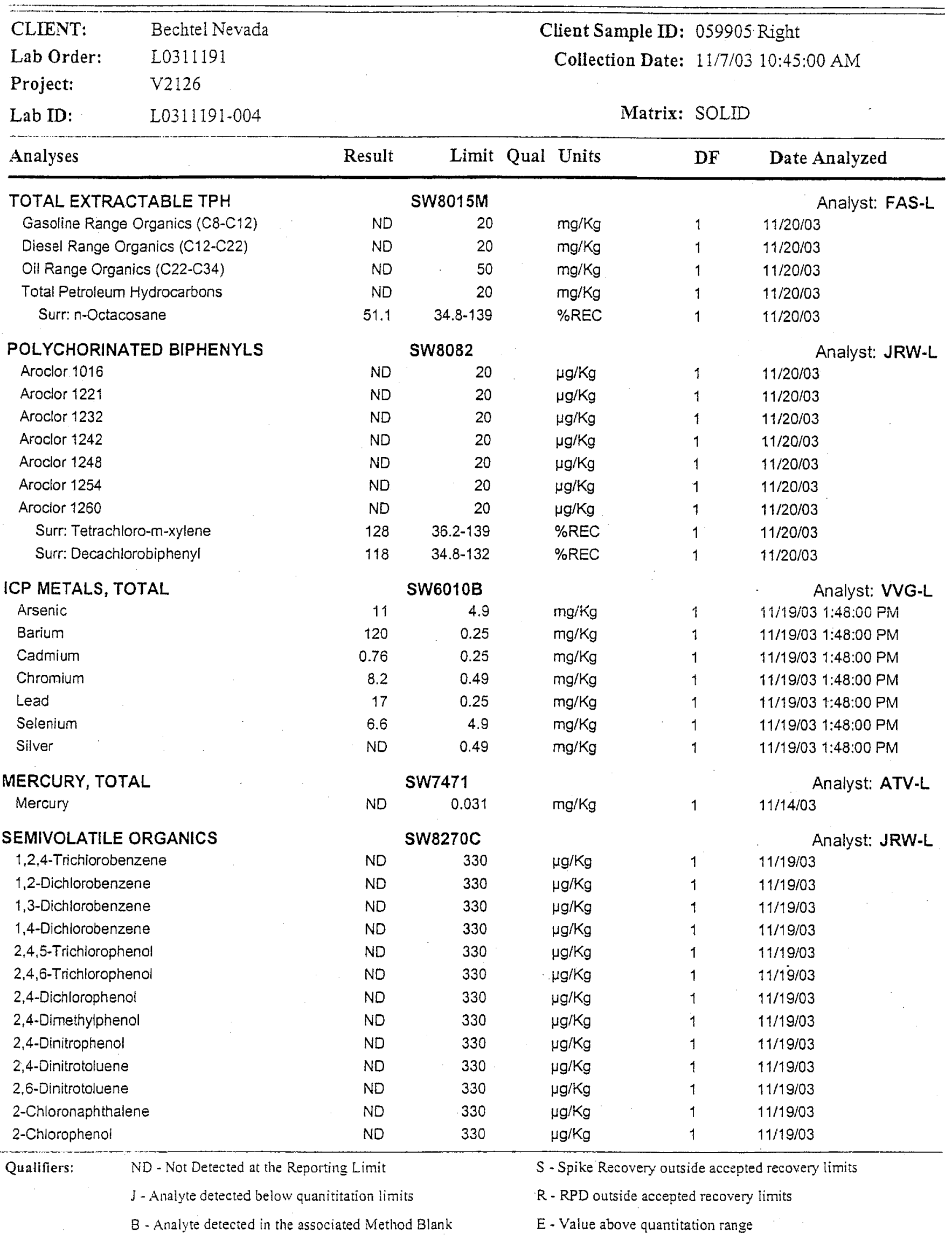

* - Value exceeds Maximum Contaminant Leve! 
NEL Laboratories, Las Vegas

Date: 26-Nov-03

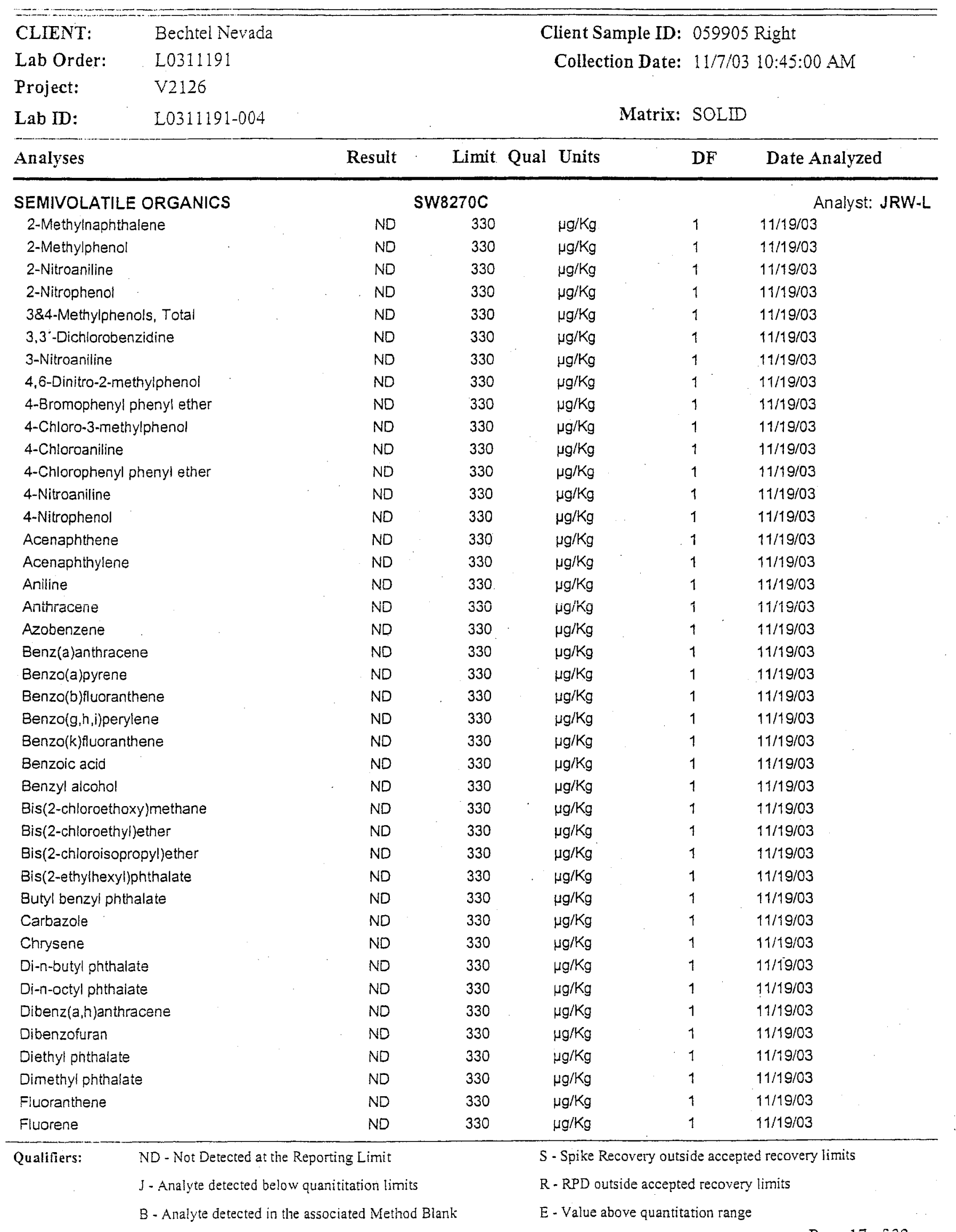

* - Value exceeds Maximum Contaminant Level

Page 17 of 32 
NEL Laboratories, Las Vegas

Date: 26-Nov-03

\begin{tabular}{lll}
\hline CLIENT: & Bechtel Nevada & Client Sample ID: 059905 Right \\
Lab Order: & L0311191 & Collection Date: $11 / 7 / 03$ 10:45:00 AM
\end{tabular}

Project: V2126

Lab ID: $\quad$ L0311191-004 Matrix: SOLID

\begin{tabular}{|c|c|c|c|c|c|c|}
\hline Analyses & Result & Limit & Qual & Units & DF & Date Analyzed \\
\hline SEMIVOLATILE ORGANICS & \multicolumn{4}{|c|}{ SW8270C } & \multicolumn{2}{|r|}{ Analyst: JRW-L } \\
\hline Hexachlorobenzene & ND & 330 & & $\mu g / \mathrm{Kg}$ & 1 & $11 / 19 / 03$ \\
\hline Hexachlorobutadiene & ND & 330 & & $\mu g / K g$ & 1 & $11 / 19 / 03$ \\
\hline Hexachlorocyclopentadiene & ND & 330 & & $\mu g / K g$ & 1 & $11 / 19 / 03$ \\
\hline Hexachloroethane & ND & 330 & & $\mu g / K g$ & 1 & $+1 / 19 / 03$ \\
\hline Indeno(1,2,3-cd)pyrene & ND & 330 & & $\mu g / K g$ & 1 & $11 / 19 / 03$ \\
\hline Isophorone & ND & 330 & & $\mu g / \mathrm{Kg}$ & 1 & $11 / 19 / 03$ \\
\hline N-Nitrosodi-n-propylamine & ND & 330 & & $\mu g / \mathrm{Kg}$ & 1 & $11 / 19 / 03$ \\
\hline N-Nitrosodimethylamine & ND & 330 & & $\mu g / \mathrm{Kg}$ & 1 & $11 / 19 / 03$ \\
\hline N-Nitrosodiphenylamine & ND & 330 & & $\mu g / \mathrm{Kg}$ & 1 & $11 / 19 / 03$ \\
\hline Naphthalene & ND & 330 & & $\mu \mathrm{g} / \mathrm{Kg}$ & 1 & $11 / 19 / 03$ \\
\hline Nitrobenzene & ND & 330 & & $\mu g / \mathrm{Kg}$ & 1 & $11 / 19 / 03$ \\
\hline Pentachlorophenol & ND & 330 & & $\mu g / \mathrm{Kg}$ & 1 & $11 / 19 / 03$ \\
\hline Phenanthrene & ND & 330 & & $\mu g / \mathrm{Kg}$ & 1 & $11 / 19 / 03$ \\
\hline Phenol & ND & 330 & & $\mu g / \mathrm{Kg}$ & 1 & $11 / 19 / 03$ \\
\hline Pyrene & ND & 330 & & $\mu g / \mathrm{Kg}$ & 1 & $11 / 19 / 03$ \\
\hline Pyridine & ND & 330 & & $\mu g / K g$ & 1 & $11 / 19 / 03$ \\
\hline Surr: 2,4,6-Tribromophenol & 72.2 & $19-122$ & & $\%$ REC & 1 & $11 / 19 / 03$ \\
\hline Surr: 2-Fluorobipheny! & 70.6 & $30-115$ & & $\% R E C$ & 1 & $11 / 19 / 03$ \\
\hline Surr: 2-Fluorophenol & 71.7 & $25-121$ & & $\%$ REC & 1 & $11 / 19 / 03$ \\
\hline Surr: 4-Terphenyl-d14 & 93.6 & $18-137$ & & $\%$ REC & 1 & $11 / 19 / 03$ \\
\hline Surr: Nitrobenzene-d5 & 64.5 & $23-\{20$ & & $\%$ REC & 1 & $11 / 19 / 03$ \\
\hline Surr: Phenol-d6 & 76.9 & $24-113$ & & \%REC & 1 & $11 / 19 / 03$ \\
\hline VOLATILES BY GC/MS & \multicolumn{3}{|c|}{ SW8260B } & \multicolumn{3}{|r|}{ Analyst: GHP-L } \\
\hline 1,1,1,2-Tetrachloroethane & ND & 50 & & $\mu g / \mathrm{Kg}$ & 10 & $11 / 14 / 03$ \\
\hline $1,1,1-$ Trichloroethane & ND & 50 & & $\mu g / \mathrm{Kg}$ & 10 & $11 / 14 / 03$ \\
\hline $1,1,2,2$-Tetrachloroethane & ND & 50 & & $\mu g / \mathrm{Kg}$ & 10 & $11 / 14 / 03$ \\
\hline 1,1,2-Trichloroethane & ND & 50 & & $\mu g / \mathrm{Kg}$ & 10 & $11 / 14 / 03$ \\
\hline 1,1-Dichloroethane & ND & 50 & & $\mu g / K g$ & 10 & $11 / 14 / 03$ \\
\hline 1,1-Dichloroethene & ND & 50 & & $\mu g / \mathrm{Kg}$ & 10 & $11 / 14 / 03$ \\
\hline 1,1-Dichloropropene & ND & 50 & & $\mu g / K g$ & 10 & $11 / 14 / 03$ \\
\hline 1,2,3-Trichlorobenzene & ND & 250 & & $\mu g / \mathrm{Kg}$ & 10 & $11 / 14 / 03$ \\
\hline 1,2,3-Trichloropropane & ND & 50 & & $\mu g / K g$ & 10 & $11 / 14 / 03$ \\
\hline 1,2,4-Trichlorobenzene & ND & 250 & & $\mu g / \mathrm{Kg}$ & 10 & $11 / 14 / 03$ \\
\hline 1,2,4-Trimethylbenzene & ND & 50 & & $\mu g / \mathrm{Kg}$ & 10 & $11 / 14 / 03$ \\
\hline 1,2-Dibromo-3-chloropropane & ND & 50 & & $\mu g / K g$ & 10 & $11 / 14 / 03$ \\
\hline 1,2-Dibromoethane & ND & 50 & & $\mu g / \mathrm{Kg}$ & 10 & $11 / 14 / 03$ \\
\hline 1,2-Dichlorobenzene & ND & 50 & & $\mu g / \mathrm{Kg}$ & 10 & $11 / 14 / 03$ \\
\hline 1,2-Dichloroethane & ND & 50 & & $\mu g / \mathrm{Kg}$ & 10 & $11 / 14 / 03$ \\
\hline 1,2-Dichloropropane & ND & 50 & . & $\mu g / \mathrm{Kg}$ & 10 & $11 / 14 / 03$ \\
\hline $1,3,5$-Trimethylbenzene & ND & 50 & & $\mu g / \mathrm{Kg}$ & 10 & $11 / 14 / 03$ \\
\hline
\end{tabular}

Qualifiers: ND-Not Detected at the Reporting Limit

$J$ - Amalyte detected below quanititation limits

B - Analyte detected in the associated Method Blank

* - Value exceeds Maximum Contaminant Level
$S$ - Spike Recovery outside accepted recovery limits

R - RPD outside accepted recovery limits

E - Value above quantitation range

Page 18 of 32 


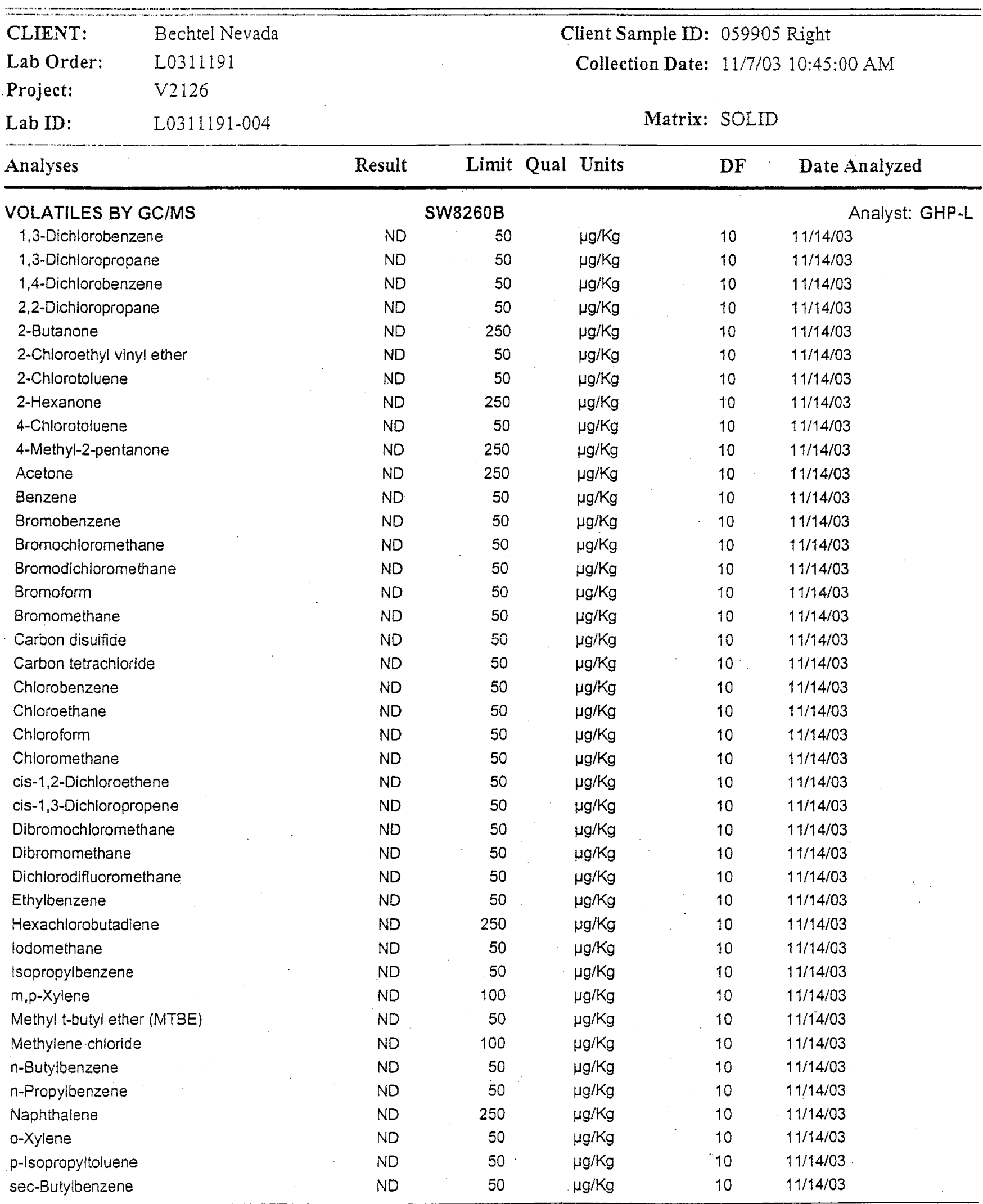

Qualifiers: ND - Not Detected at the Reporting Limit

J - Analyte detected below quanititation limits

B - Analyte detected in the associated Method Blank

* - Value exceeds Maximum Contaminant Level
$S$ - Spike Recovery outside accepted recovery limits

$R$ - RPD outside accepted recovery limits

E- Value above quantitation range

Page 19 of 32 


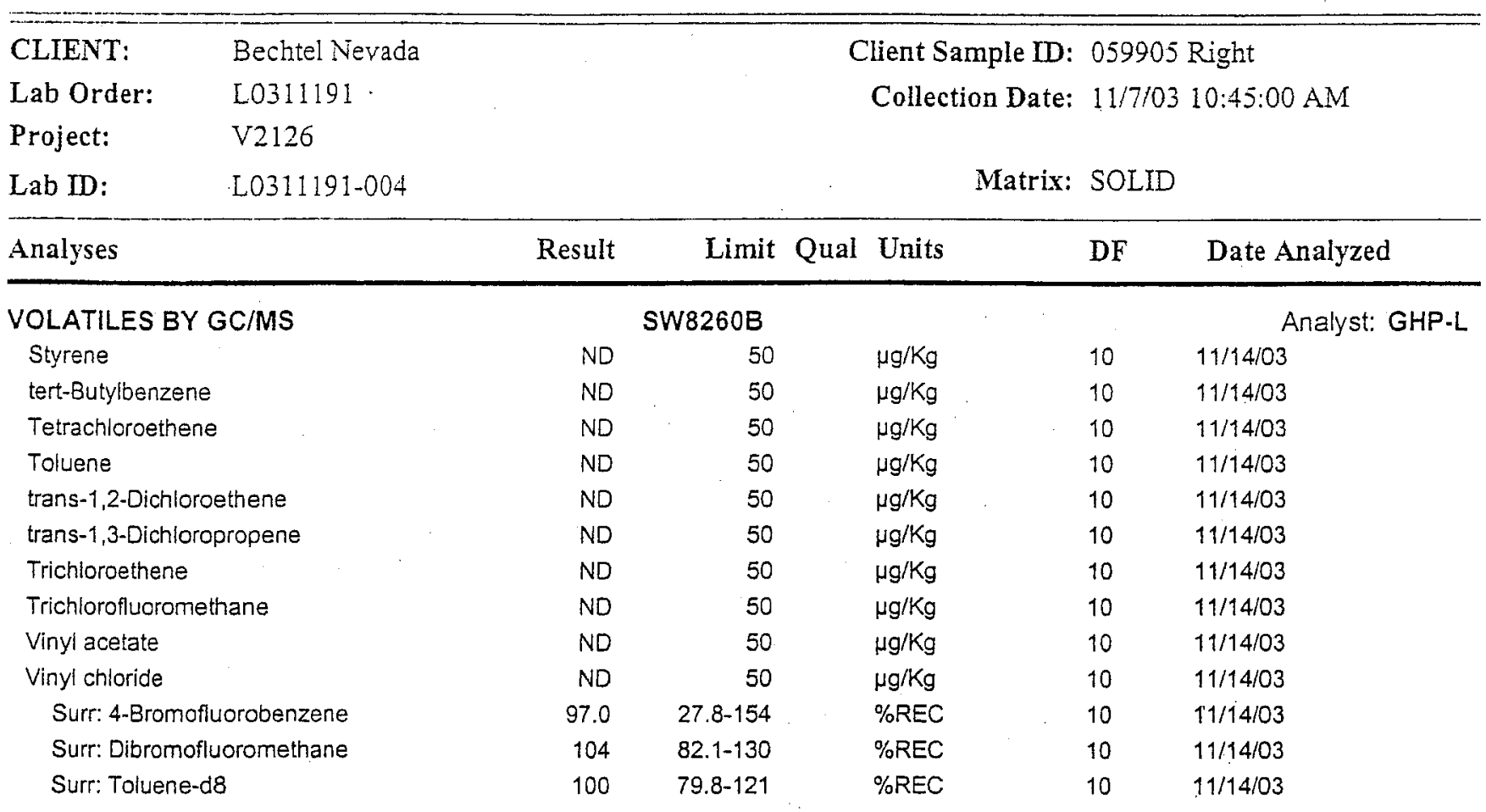

\begin{tabular}{|c|c|c|}
\hline \multirow[t]{3}{*}{ Qualifiers: } & ND - Not Detected at the Reporting Limit & S - Spike Recovery outside accepted recovery limits \\
\hline & $\mathrm{J}$ - Analyte detected below quanititation limits & R - RPD outside accepted recovery limits \\
\hline & B - Analyte detected in the associated Method Blank & E - Value above quantitation range \\
\hline
\end{tabular}

\footnotetext{
* - Value exceeds Maximum Contaminant Level
} 


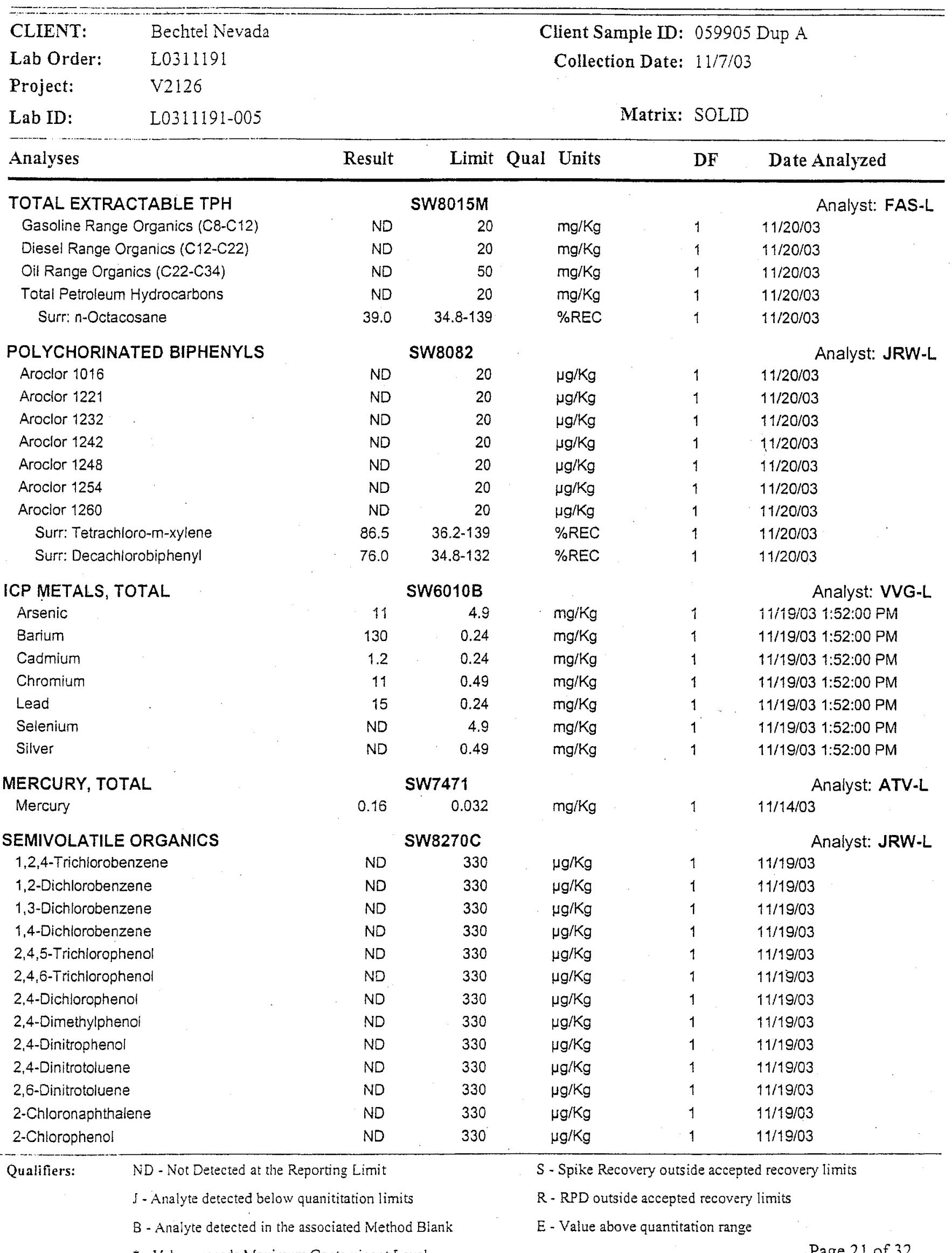

* - Value exceeds Maximum Contaminant Level 
NEL Laboratories, Las Vegas

Date: 26-Nov-03

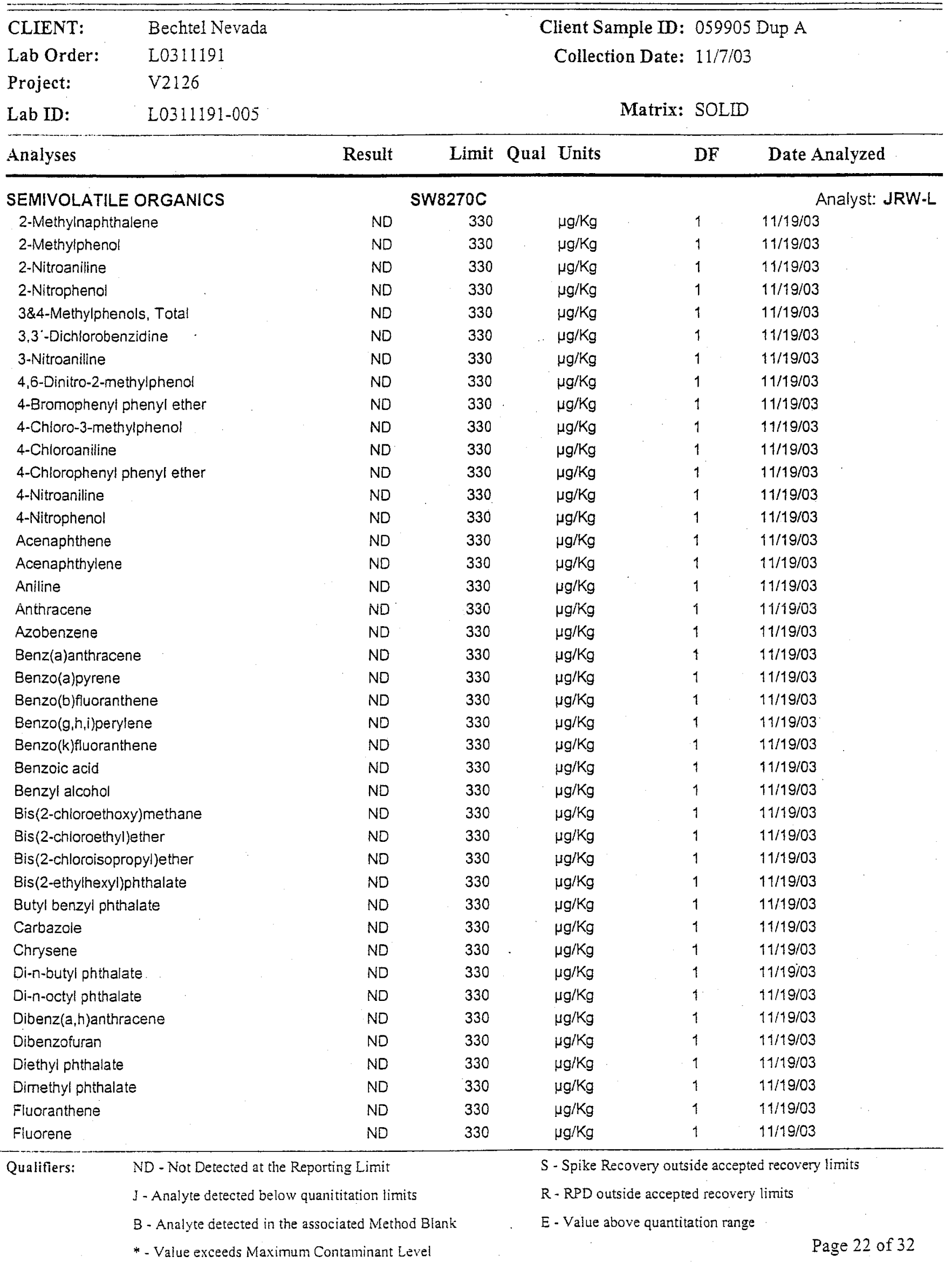


NEL Laboratories, Las Vegas

Date: 26-Nov-03

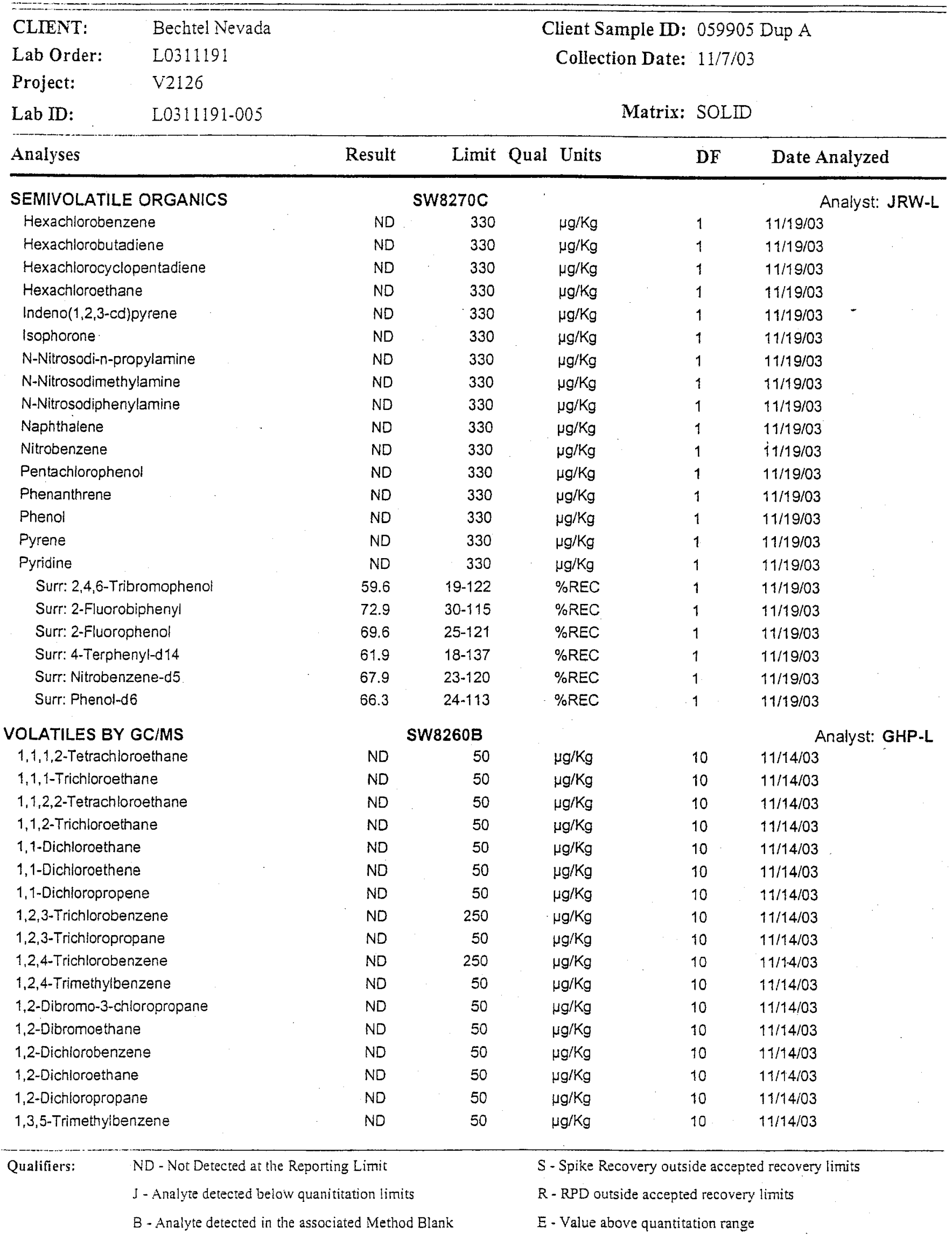

* - Value exceeds Mraximum Contaminant Level 
Date: $26-\mathrm{Nov}-03$

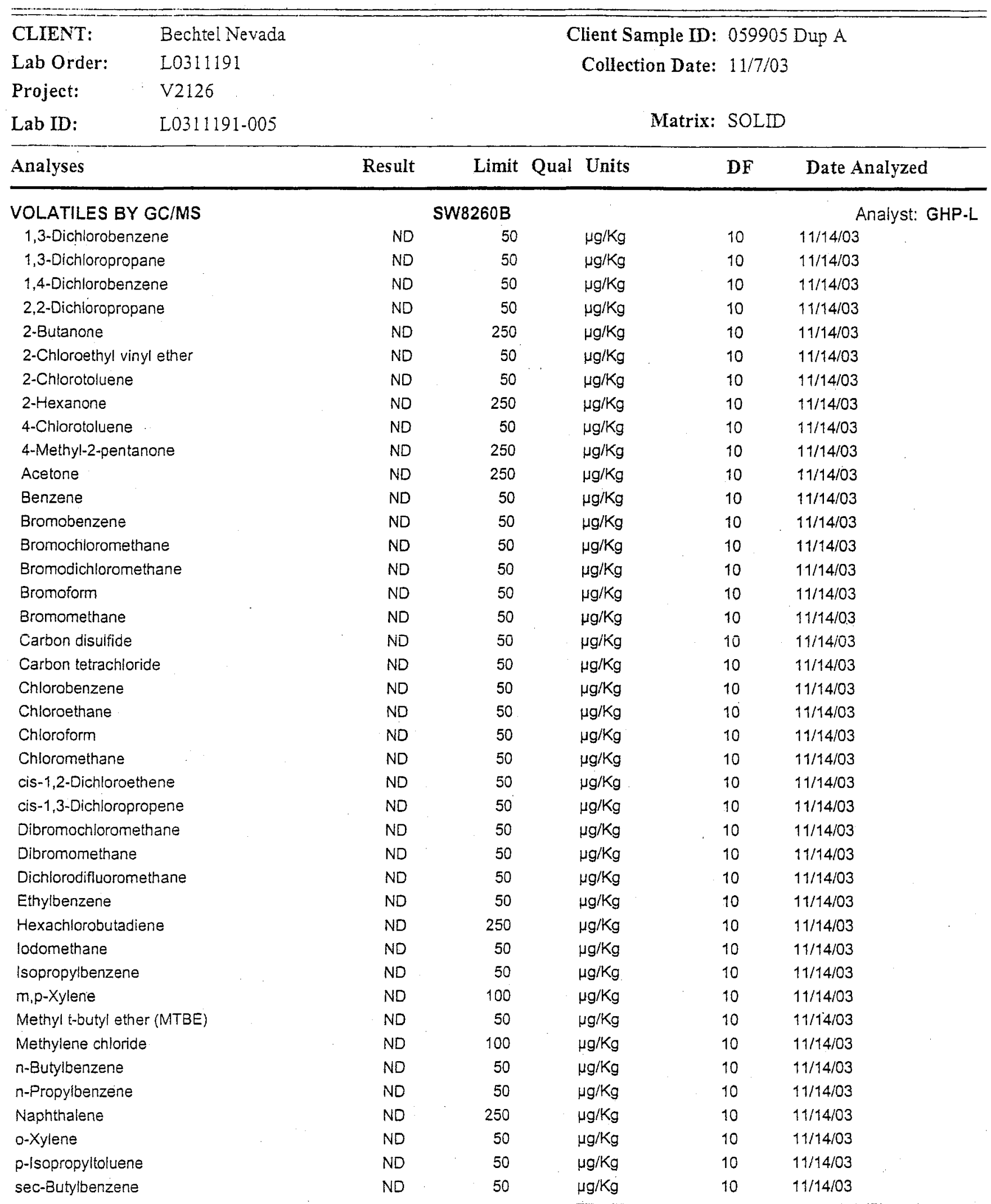

Qualifiers: ND - Not Detected at the Reporting Limit

S - Spike Recovery outside accepted recovery linits

J - Analyte detected below quanititation limits

R - RPD outside accepted recovery limits

B - Analyte detected in the associated Method Blank

$E$ - Value above quantitation range

* - Value exceeds Maximum Contaminant Level 
NEL Laboratories, Las Vegas

Date: 26-Nov-03

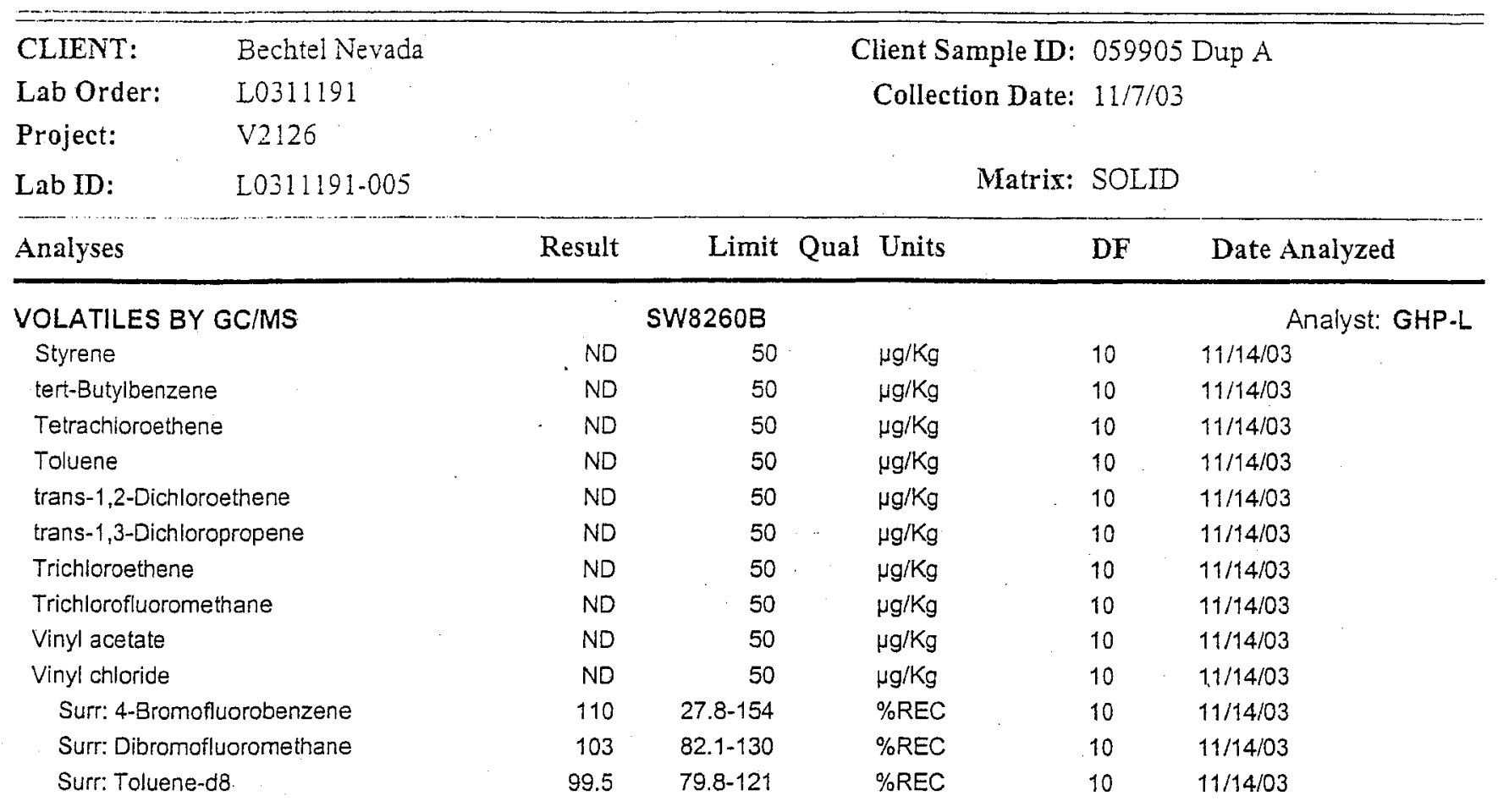

\begin{tabular}{|c|c|c|}
\hline \multirow{2}{*}{ Qualifiers: } & ND - Not Detected at the Reporting Limit & S - Spike Recovery outside accepted recovery limits \\
\hline & J - Analyte detected below quanititation limits & R - RPD outside accepted recovery limits \\
\hline & B - Analyte detected in the associated Method Blank & E-Value above quantitation range \\
\hline
\end{tabular}

* - Value exceeds Maximum Contaminant Level 
Date: 26-Nov-03

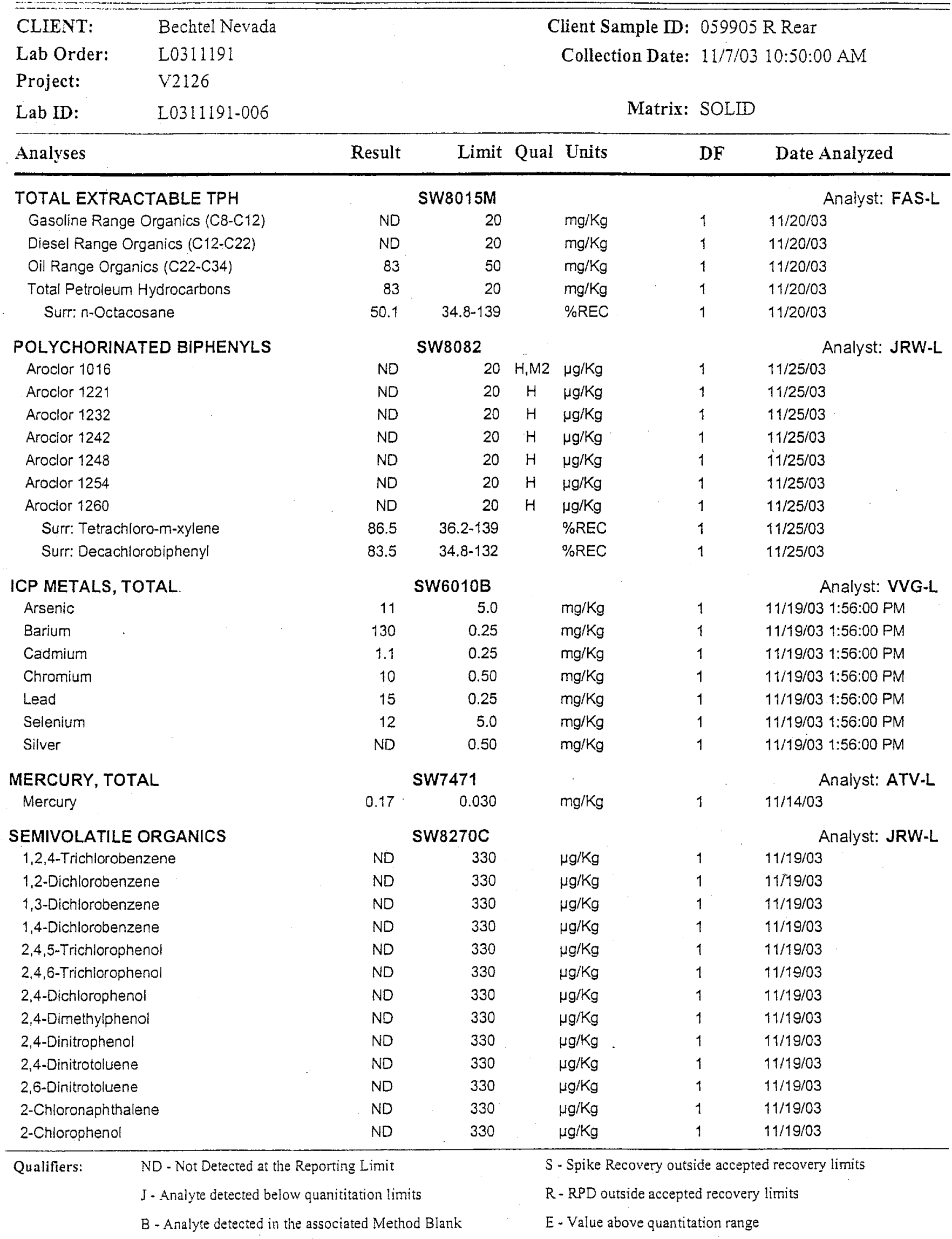

* - Value exceeds Maximum Contaminant Level 
Date: 26-Nov-03

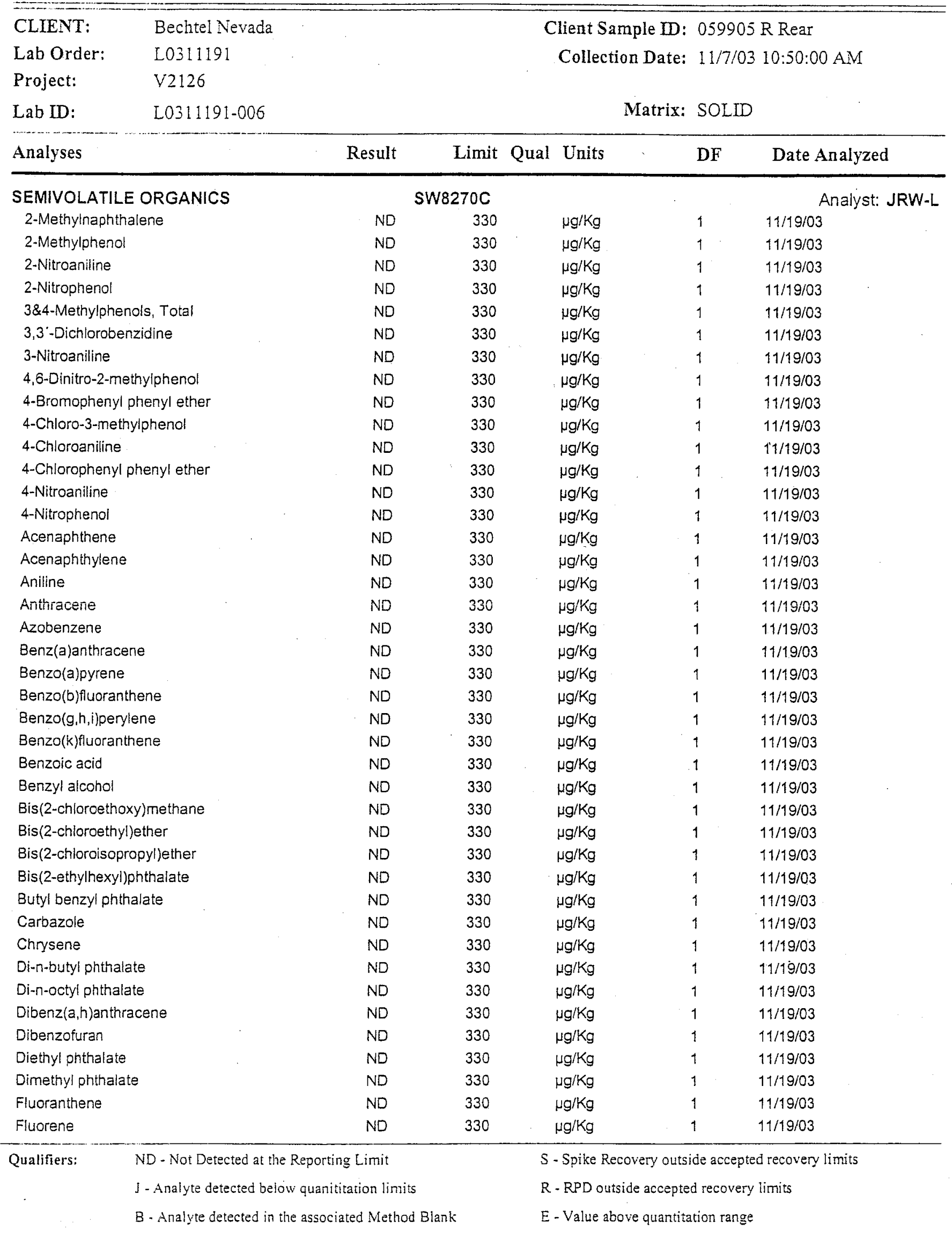

* . Value exceeds Maximum Contaminant Level 
Date: 26-Nov-03

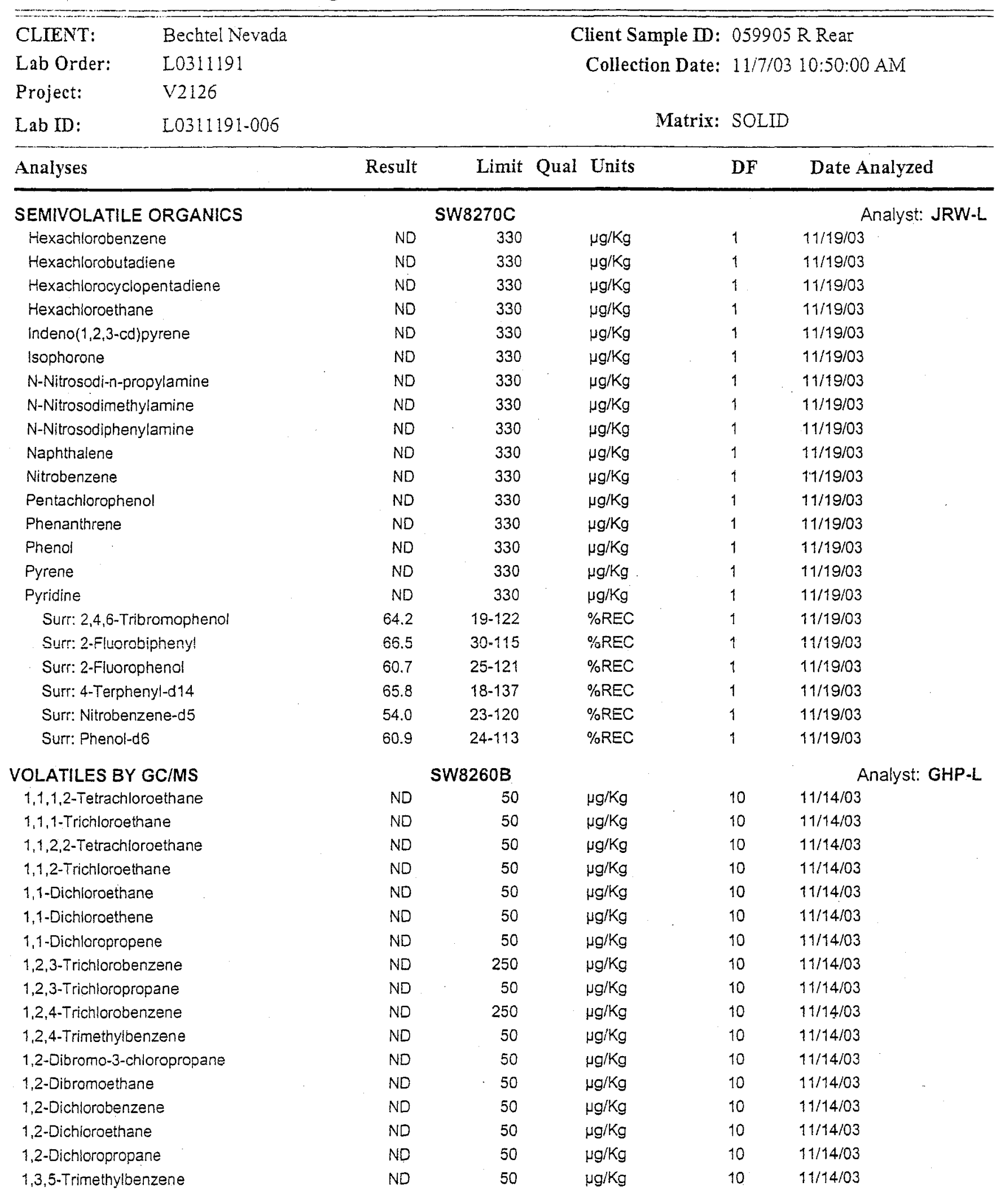

Qualifiers: ND - Not Detected at the Reporting Limit

J - Analyte detected below quanititation limits

B - Analyte detected in the associated Method Blank

* - Value exceeds Maximum Contaminant Level
S - Spike Recovery outside accepted recovery limits

$R$ - RPD outside accepted recovery limits

E - Value above quantitation range 
NEL Laboratories, Las Vegas

Date: 26-Nov-03

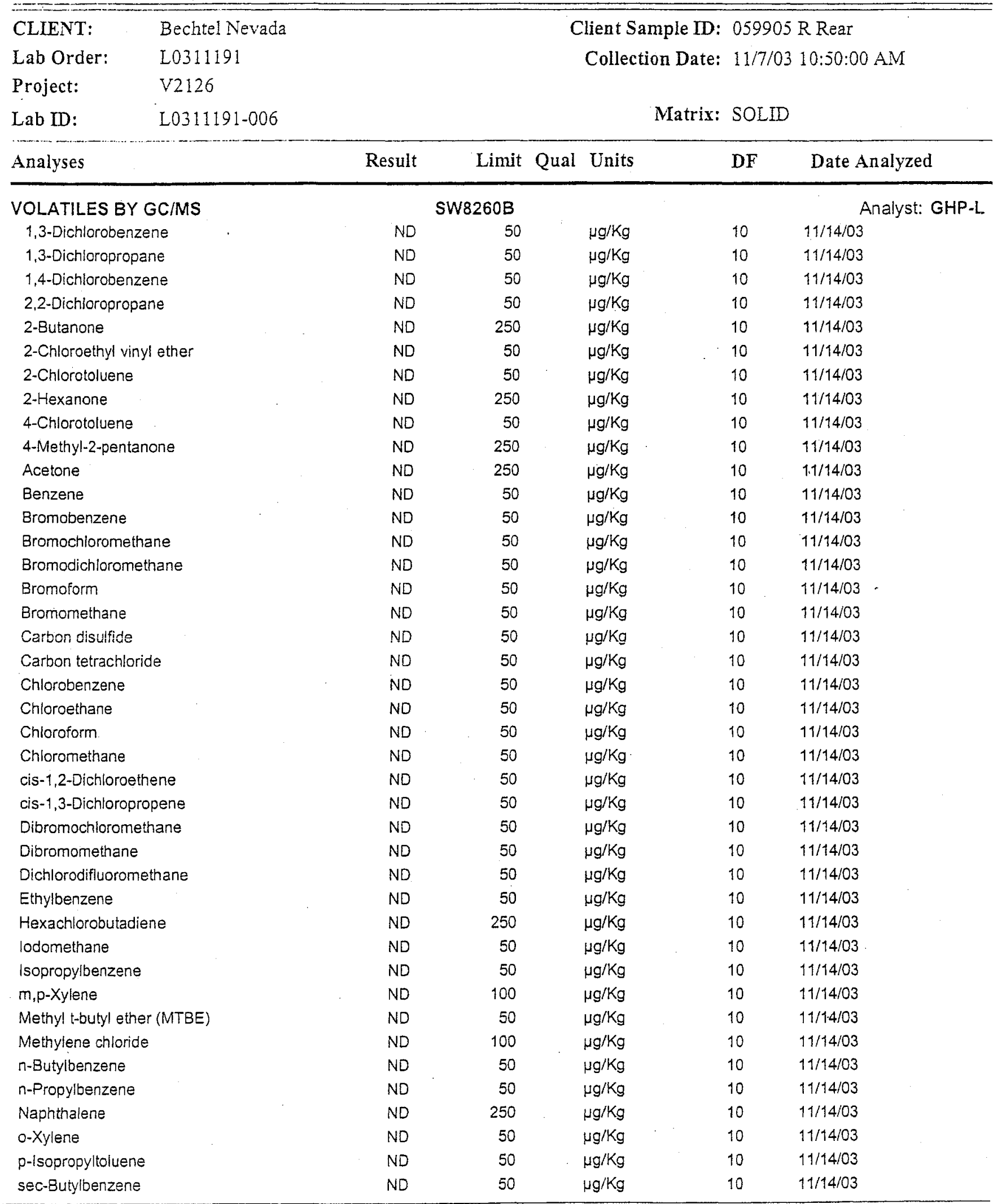

Qualifiers: ND - Not Detected at the Reporting Linit

S - Spike Recovery outside accepted recovery limits

i - Analyte detected below quanititation limits

R-RPD outside accepted recovery limits

B - Aralyte detected in the associated Method Blank

E-Value above quantitation range

* - Value exceeds Maximum Contaminant Level 
NEL Laboratories, Las Vegas

Date: 26-Nov-03

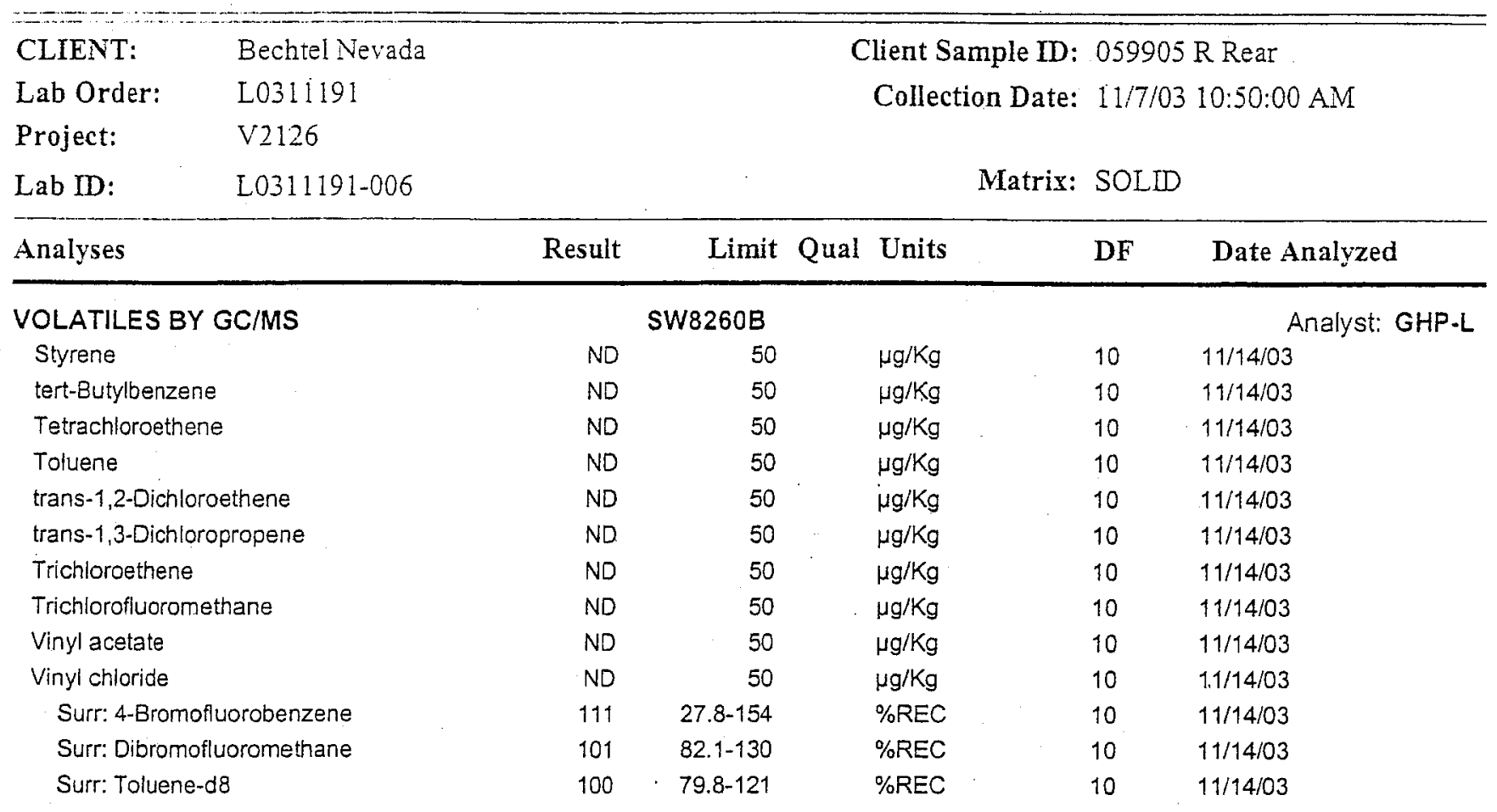

\begin{tabular}{lll}
\hline Qualifiers: & ND - Not Detected at the Reporting Limit & S - Spike Recovery outside accepted recovery linits \\
$J$ - Aralyte detected below quanititation limits & $R$ - RPD outside accepted recovery limits \\
B - Analyte detected in the associated Method Blank & E - Value above quantitation range
\end{tabular}

* - Value exceeds Maximum Contaminant Level 
NEL Laboratories, Las Vegas

Date: 26-Nov-03

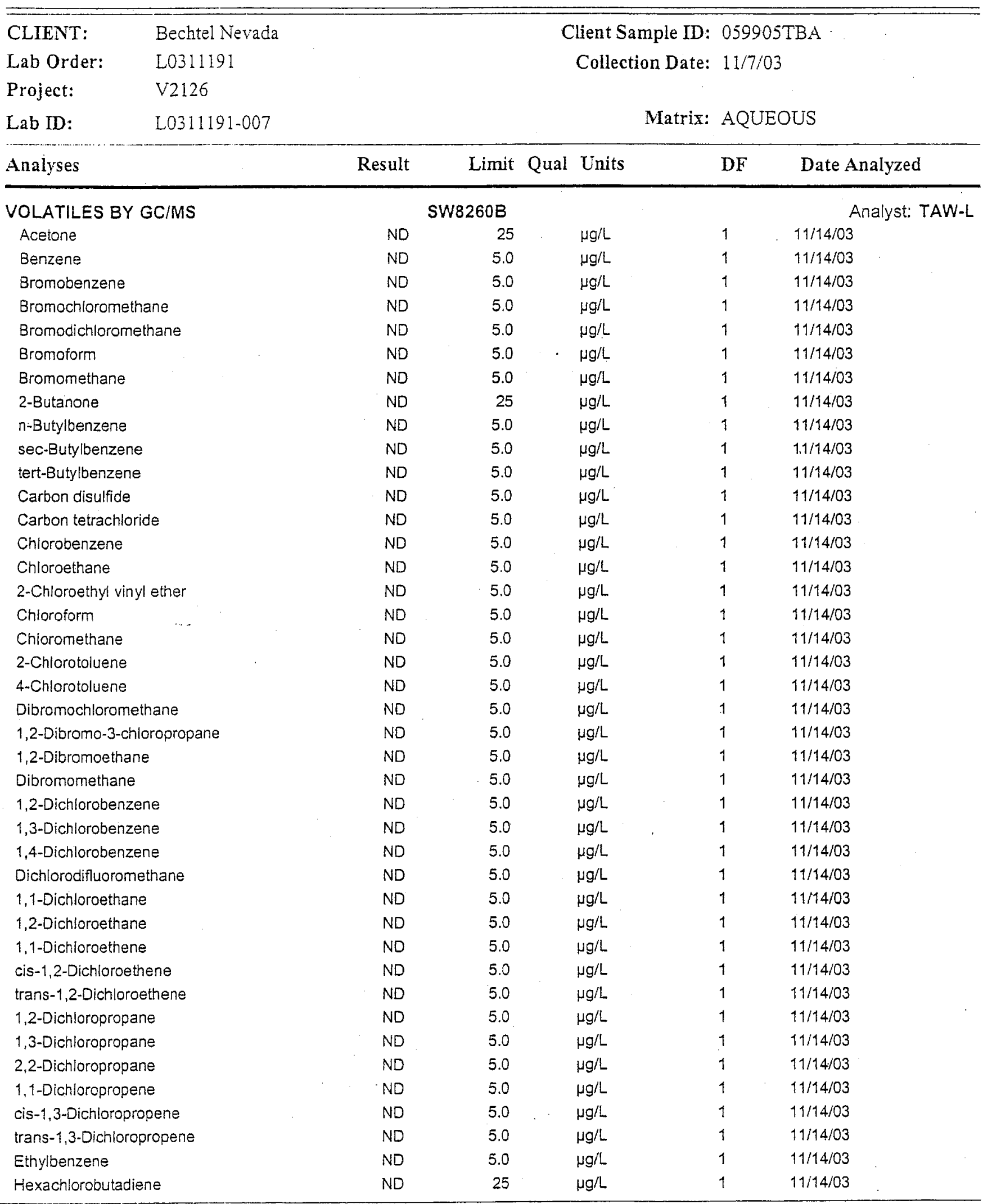

Qualifiers: ND-Not Detected at the Reporting Limit

$S$ - Spike Recovery outside accepted recovery limits

J.- Analyte detected below quanititation limits

$R$ - RPD outside accepted recovery limits

B-Analyte detected in the associated Method Blank

E - Value above quantitation range

* - Value exceeds Maximum Contaminant Level 
NEL Laboratories, Las Vegas

Date: 26-Nov-03

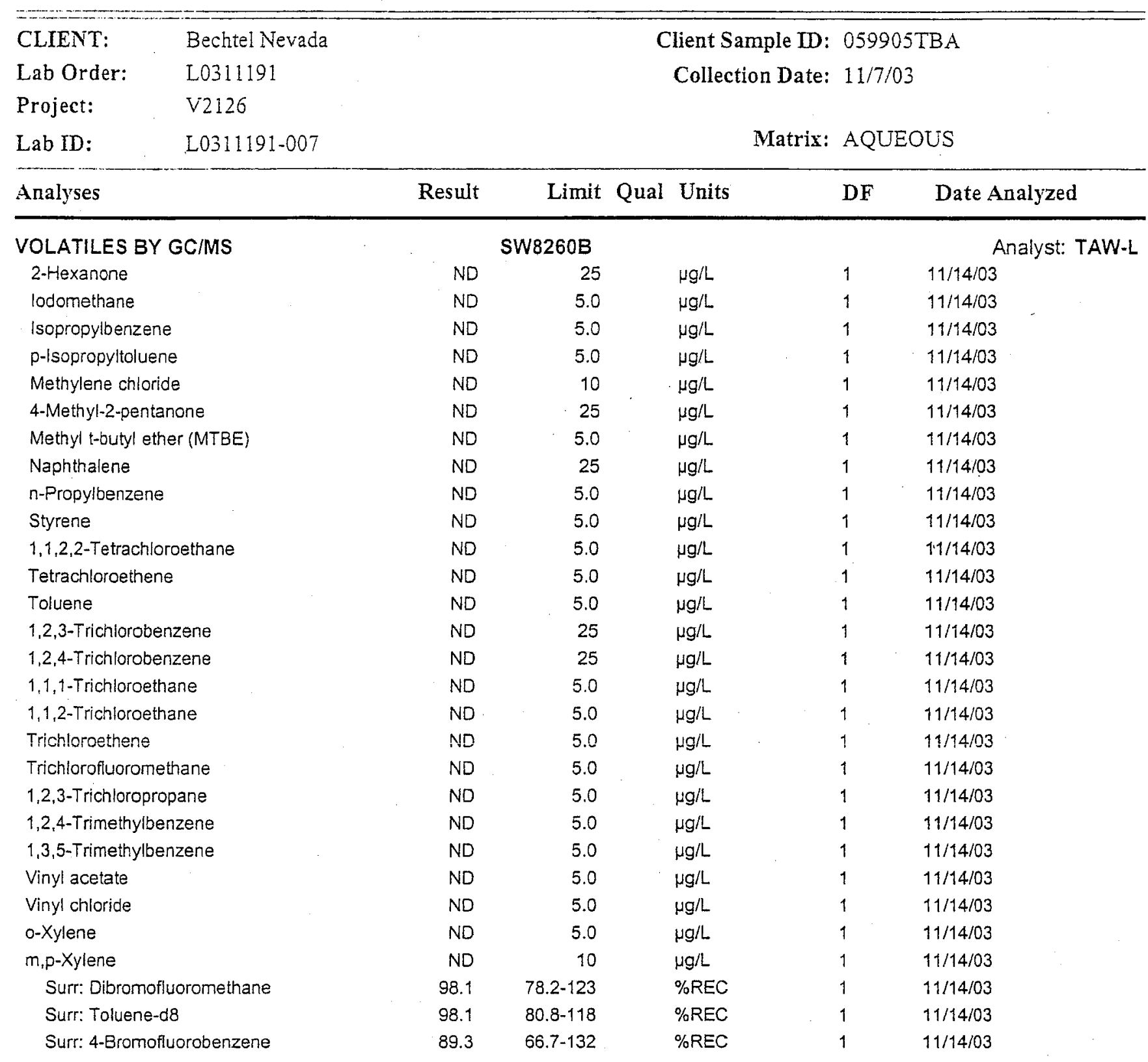

$\begin{array}{lll}\text { Qualifiers: } & \text { ND - Not Detected at the Reporting Limit } & \text { S - Spike Recovery outside accepted recovery limits } \\ \text { J - Analyte detected below quanititation limits } & \text { R - RPD outside accepted recovery limits } \\ \text { B - Analyte detected in the associated Method Blank } & \text { E - Value above quantitation range }\end{array}$

* - Value exceeds Maximum Contaminant Level 
Closure Report - CAU 167

Section: Appendix A

Revision: 1

Date: April 2005

\section{SAMPLE DELIVERY GROUP}

V2127 
Closure Report - CAU 167

Section: Appendix A

Revision: 1

Date: April 2005

THIS PAGE INTENTIONALLY LEFT BLANK 
$\frac{b}{3}$

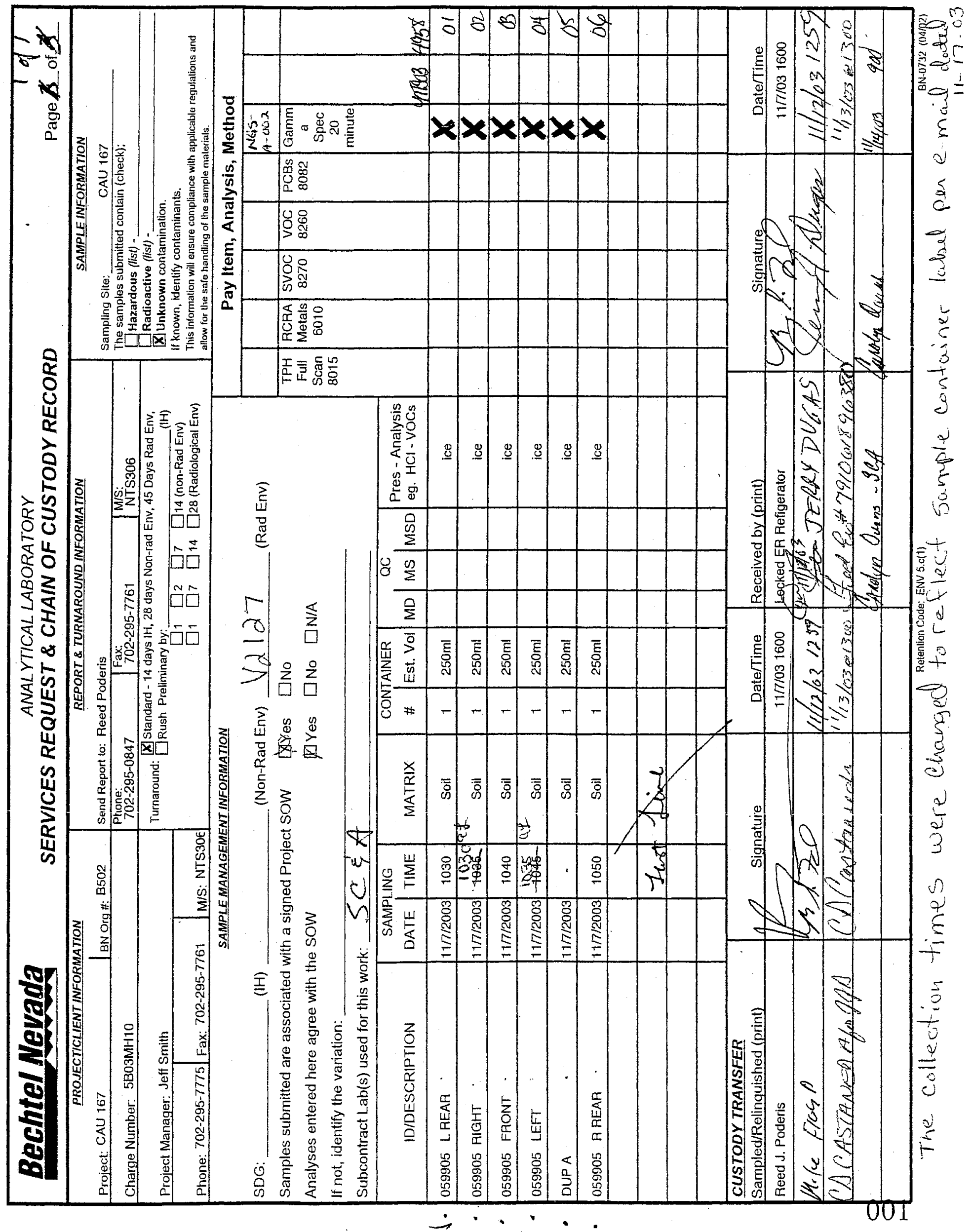


Closure Report - CAU 167

Section: Appendix A

Revision: 0

Date: April 2004

THIS PAGE INTENTIONALLY LEFT BLANK 


\section{Sanford Cohen \& Associates \\ Southeastern Environmental Laboratory}

Radioanalytical Results

Report Identification Number: V2127

\begin{tabular}{|c|c|c|c|c|c|c|}
\hline \multicolumn{2}{|c|}{$\begin{array}{l}\text { Project Name: Bechtel Nevada } \\
\text { Site Sample ID: } 059905 \text { L REAR }\end{array}$} & \multicolumn{3}{|c|}{ Chain-of-Custody Number: NONE } & \multicolumn{2}{|c|}{ Matrix: Soil } \\
\hline Method Number & Radionuclide & $\begin{array}{l}\text { Laboratory } \\
\text { Sample 10 } \\
\end{array}$ & $\begin{array}{l}\text { Activity } \\
\text { (pCi/q) }\end{array}$ & $\begin{array}{l}2 \sigma \text { TPU } \\
(\mathrm{pC} / / \mathrm{g})\end{array}$ & $\begin{array}{l}\text { Total Error } \\
(\mathrm{pC \textrm {i } / \mathrm { g } )} \\
\end{array}$ & $\begin{array}{r}\mathrm{MDA} \\
(\mathrm{pC} / / \mathrm{g}) \\
\end{array}$ \\
\hline EPA 901.1 & $\mathrm{~K}-40$ & NTS03-4958-01 & 22.3 & 2.12 & 3.08 & 0.261 \\
\hline EPA 901.1 & $c 0-60$ & NTS03-4958-01 - & -0.027 & 0.022 & 0.022 & 0.031 \\
\hline EPA 901.1 & Y.88 & NTS03-4958-01 & 0.011 & 0.012 & 0.012 & 0.025 \\
\hline EPA 901.1 & RU-106 & NTS03-4958-01 & 0.058 & 0.150 & 0.150 & 0.256 \\
\hline EPA 901.1 & SB-125 & NTS03-4958-01 & 0.034 & 0.043 & 0.044 & 0.076 \\
\hline EPA 901.1 & CS-134 & NTS03-4958-01 & 0.001 & 0.018 & 0.018 & 0.026 \\
\hline EPA 901.1 & CS-137 & NTS03-4958-01 & 0.130 & 0.032 & 0.035 & 0.029 \\
\hline ËPA 901.1 & CE-144 & NTS03-4958-01 & -0.087 & 1.81 & 1.81 & 0.212 \\
\hline EPA 901.1 & PM-144 & NTS03-4958-01 & 0.012 & 0.016 & 0.016 & 0.025 \\
\hline EPA 901.1 & PM-146 & NTSO3-4958-01 & 0.004 & 0.021 & 0.021 & 0.036 \\
\hline EPA 901.1 & EU-152 & NTS03-4958-01 & 0.025 & 0.048 & 0.048 & 0.078 \\
\hline EPA 901.1 & EU-154 & NTS03-4958-01 & 0.000 & 0.000 & 0.000 & 0.056 \\
\hline EPA 901.1 & EU-155 & NTS03-4958-01 & 0.388 & 0.088 & 0.096 & 0.122 \\
\hline EPA 901.1 & TL-208 & NTS03-4958-01 & 0.542 & 0.069 & 0.088 & 0.031 \\
\hline EPA 901.1 & $\mathrm{~B} \mid-211$ & NTS03-4958-01 & 2.44 & 0.621 & 0.667 & 0.177 \\
\hline EPÁ 901.1 & $B 1-212$ & NTS03-4958-01 & 0.955 & 0.290 & 0.306 & 0.226 \\
\hline EPA 901.1 & PB-212 & NTS03-4958-01 & 1.58 & 0.466 & 0.492 & 0.047 \\
\hline EPA 901.1 & $\mathrm{BI}-214$ & NTS03-4958-01 & 0.808 & 0.110 & 0.137 & 0.055 \\
\hline EPA 901.1 & PB-214 & NTS03-4958-01 & 0.849 & 0.214 & 0.231 & 0.062 \\
\hline EPA 901.1 & RA-224 & NTS03-4958-01 & 1.65 & 0.852 & 1.08 & 0.539 \\
\hline EPA 901.1 & RA-226 & NTS03-4958-01 & 2.44 & 0.688 & 0.730 & 0.651 \\
\hline EPA 901.1 & $A C-228$ & NTS03-4958-01 & 1.65 & 0.229 & 0.282 & 0.106 \\
\hline EPA 901.1 & $\mathrm{TH}-234$ & NTS03-4958-01 & 1.30 & 0.399 & 0.420 & 0.510 \\
\hline EPA 901.1 & U-235 & NTS03-4958-01 & 0.148 & 0.042 & 0.044 & 0.040 \\
\hline EPA 901.1 & U-238 & NTS03-4958-01 & 0.913 & 3.08 & 3.08 & 5.45 \\
\hline EPA 901.1 & $A M-241$ & NTS03-4958-01 & 0.070 & 0.090 & 0.090 & 0.152 \\
\hline
\end{tabular}

Quality Control Samples

Radionuclide Laboratory Control (LC) Laboratory Duplicate (LD) Matrix Spike (MS) Preparation Blank (PB)

Gamma SCAQC-4958-LC1 SCAQC-4958-LD1 SCAQC-4958-PB




\section{Sanford Cohen \& Associates \\ Southeastern Environmental Laboratory}

Radioanalytical Results

Report Identification Number: V2127

\begin{tabular}{|c|c|c|c|c|c|c|}
\hline \multicolumn{2}{|c|}{$\begin{array}{l}\text { Project Name: Bechtel Neyada } \\
\text { Site Sample ID: } 059905 \text { RIGHT }\end{array}$} & \multicolumn{3}{|c|}{ Chain-of-Custody Number: NONE } & \multicolumn{2}{|c|}{ Matrix: Soil } \\
\hline Method Number & Radionuclide & $\begin{array}{l}\text { Laboratory } \\
\text { Sample } 10 \\
\end{array}$ & $\begin{array}{l}\text { Activity } \\
\text { (pci/g) }\end{array}$ & $\begin{array}{l}2 \sigma \text { TPU } \\
(\mathrm{pCi} / \mathrm{q})\end{array}$ & $\begin{array}{l}\text { Total Error } \\
(\mathrm{DC \textrm {i } / \mathrm { g } )} \\
\end{array}$ & $\begin{array}{l}\mathrm{MDA} \\
(\mathrm{pCi} / \mathrm{g})\end{array}$ \\
\hline EPA 901.1 & $K-40$ & NTS03-4958-02 & 24.3 & 2.25 & 3.31 & 0.186 \\
\hline EPA 901.1 & $\mathrm{CO}-60$ & NTS03-4958-02 & -0.005 & 0.020 & 0.020 & 0.028 \\
\hline EPA 901.1 & Y-88 & NTSO3-4958-02 & 0.004 & 0.012 & 0.012 & 0.022 \\
\hline EPA 901.1 & RU-106 & NTS03-4958-02 & -0.007 & 0.128 & 0.128 & 0.212 \\
\hline EPA 901.1 & SB-125 & NTS03-4958-02 & 0.015 & 0.039 & 0.039 & 0.067 \\
\hline EPA 901.1 & CS-134 & NTS03-4958-02 & 0.010 & 0.015 & 0.015 & 0.023 \\
\hline EPA 901.1 & CS -137 & NTS03-4958-02 & 0.279 & 0.039 & 0.048 & 0.025 \\
\hline EPA 901.1 & CE-144 & NTS03-4958-02 & 0.399 & 1.61 & 1.61 & 0.184 \\
\hline EPA 901.1 & PM-144 & NTS03-4958-02 & 0.009 & 0.015 & 0.015 & 0.021 \\
\hline EPA 901.1 & $P M-146$ & NTS03-4958-02 & 0.025 & 0.020 & 0.020 & 0.035 \\
\hline EPA 901.1 & EU-152 & NTS03-4958-02 & 0.054 & 0.043 & 0.043 & 0.074 \\
\hline EPA 901.1 & EU-154 & NTS03-4958-02 & 0.000 & 0.000 & 0.000 & 0.052 \\
\hline EPA 901.1 & EU-155 & NTS03-4958-02 & 0.416 & 0.087 & 0.096 & 0.108 \\
\hline EPA 901.1 & TL-208 & NTS03-4958-02 & 0.457 & 0.058 & 0.074 & 0.026 \\
\hline EPA 901.1 & $\mathrm{BI}-211$ & NTS03-4958-02 & 2.49 & 0.545 & 0.599 & 0.142 \\
\hline EPA 901.1 & $\mathrm{~B} \mid-212$ & NTS03-4958-02 & 1.03 & 0.234 & 0.256 & 0.199 \\
\hline EPA 901.1 & PB-212 & NTS03-4958-02 & 1.42 & 0.348 & 0.376 & 0.044 \\
\hline EPA 901.1 & $\mathrm{~B} \mid-214$ & NTS03-4958-02 & 0.848 & 0.107 & 0.137 & 0.047 \\
\hline EPA 901.1 & RA-224 & NTS03-4958-02 & 3.47 & 1.06 & 1.75 & 0.505 \\
\hline EPA 901.1 & RA-226 & NTSO3-4958-02 & 2.59 & 0.678 & 0.726 & 0.567 \\
\hline EPA 901.1 & $A C-228$ & NTS03-4958-02 & 1.57 & 0.208 & 0.260 & 0.093 \\
\hline EPA 901.1 & TH-234 & NTSO3-4958-02 & 2.98 & 0.534 & 0.612 & 0.456 \\
\hline EPA 901.1 & U-235 & NTS03-4958-02 & 0.157 & 0.041 & 0.044 & 0.034 \\
\hline EPA 901.1 & U-238 & NTS03-4958-02 & 5.52 & 2.96 & 3.01 & 5.36 \\
\hline EPA 901.1 & $A M-241$ & NTSO3-4958-02 & 0.028 & 0.109 & 0.109 & 0.159 \\
\hline
\end{tabular}

\begin{tabular}{|cllll|}
\hline & \multicolumn{2}{c}{ Quality Control Samples } & \\
$\frac{\text { Radionuclide }}{\text { Gamma }}$ & $\frac{\text { Laboratory Control (LC) }}{\text { SCAQC-4958-LC1 }}$ & $\frac{\text { Laboratory Duplicate (LD) }}{\text { SCAQC-4958-LD1 }}$ & Matrix Spike (MS) & Preparation Blank (PB) \\
\hline
\end{tabular}




\section{Sanford Cohen \& Associates \\ Southeastern Environmental Laboratory}

Radioanalytical Results

Report Identification Number: V2127

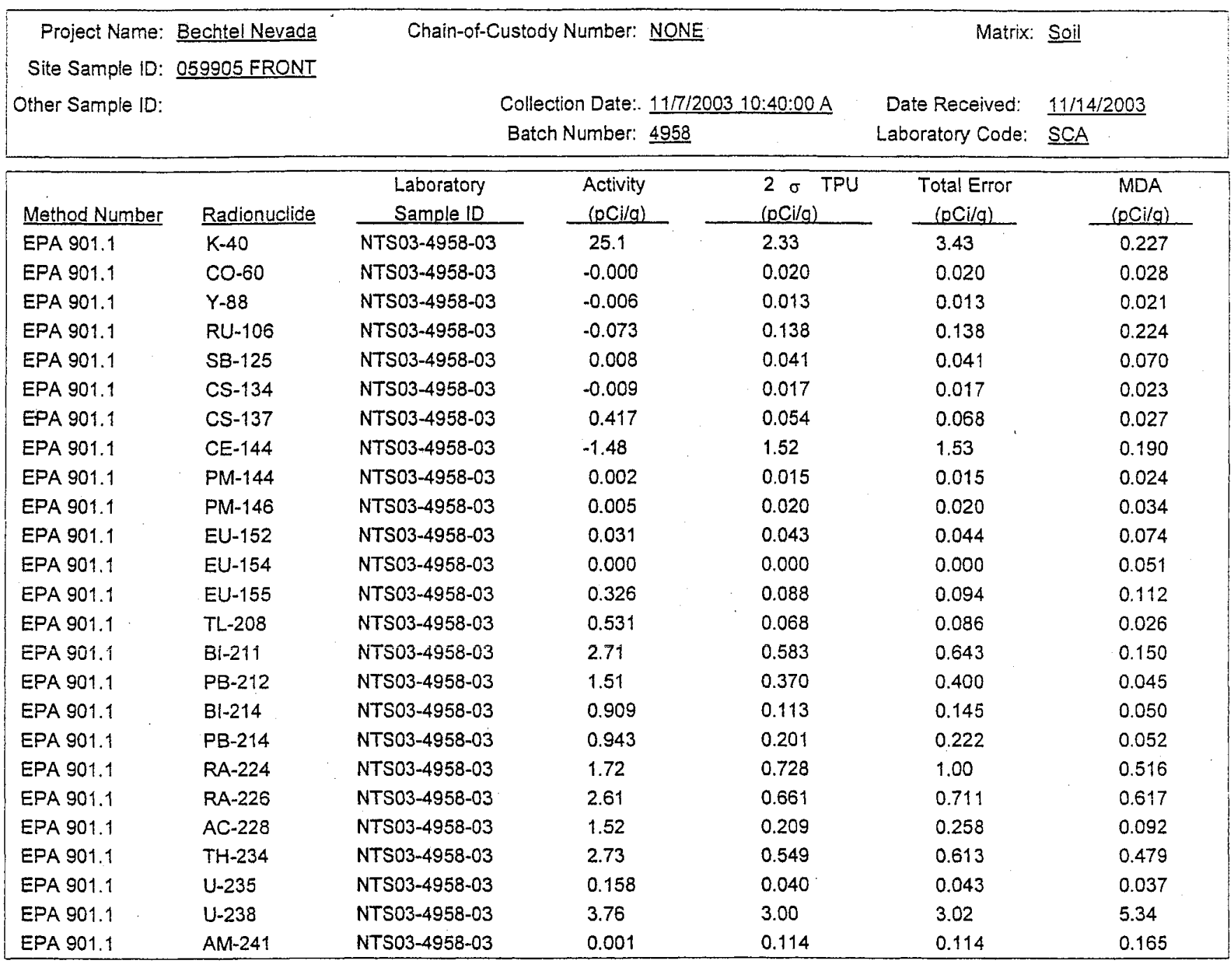

\begin{tabular}{|cllll|}
\hline & & \multicolumn{2}{c|}{ Quality Control Samples } \\
Radionuclide & Laboratory Control (LC) & Laboratory Duplicate (LD) & Matrix Spike (MS) & Preparation Blank (PB) \\
\hline Gamma & SCAQC-4958-LC1 & SCAQC-4958-LD1 & SCAQC-4958-PB \\
\hline
\end{tabular}




\section{Sanford Cohen \& Associates \\ Southeastern Environmental Laboratory}

Radioanalytical Results

Report Identification Number: V2127

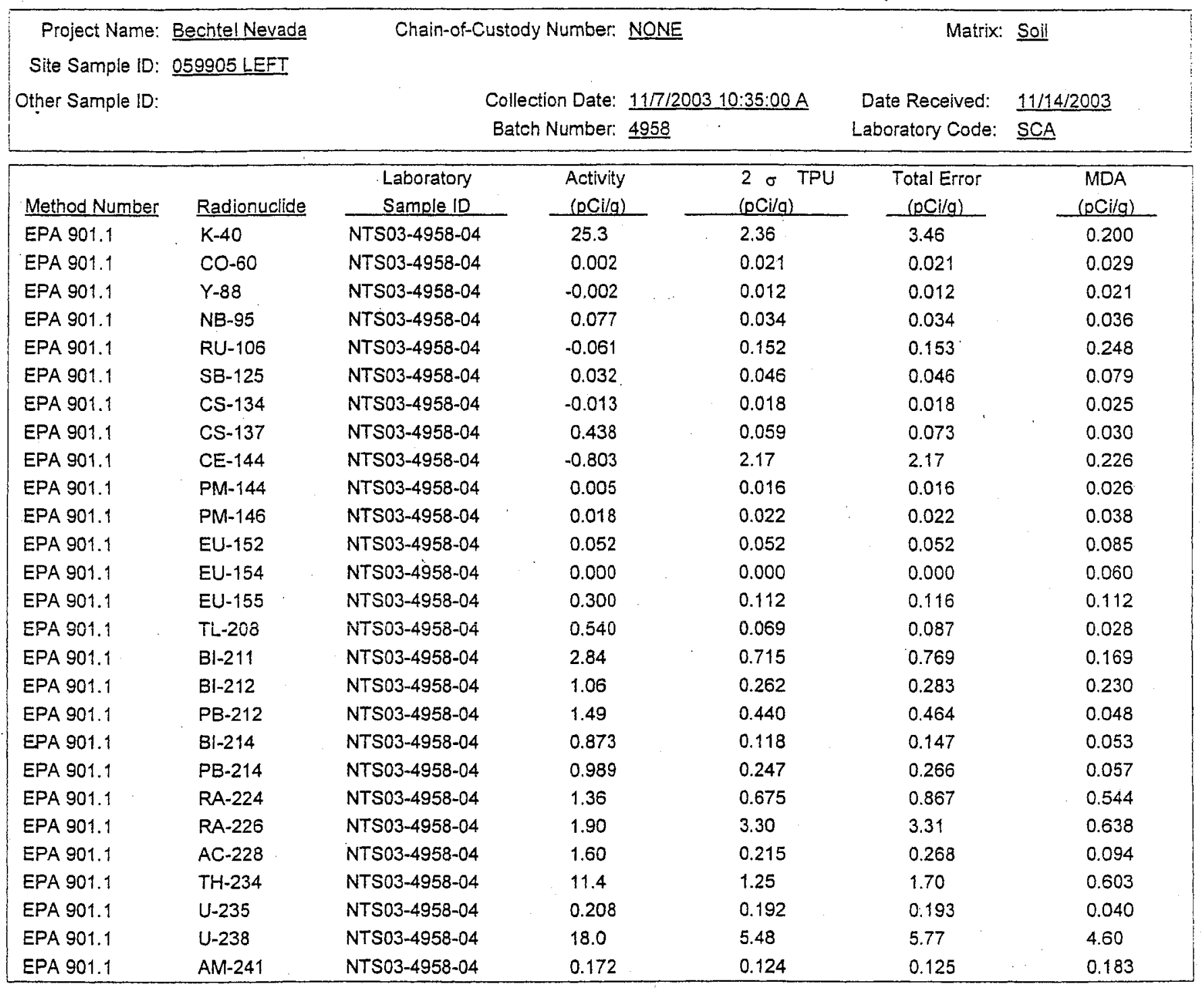

\begin{tabular}{|lllll|}
\hline Radionuclide & \multicolumn{2}{c}{ Quality Control Samples } \\
Gamma & $\frac{\text { Laboratory Control (LC) }}{\text { SCAQC-4958-LC1 }}$ & $\frac{\text { Laboratory Duplicate (LD) }}{\text { SCAQC-4958-LD1 }}$ & Matrix Spike (MS) & Preparation Blank (PB) \\
\hline
\end{tabular}




\section{Sanford Cohen \& Associates \\ Southeastern Environmental Laboratory \\ Radioanalytical Results}

Report Identification Number: V2127

\begin{tabular}{|c|c|c|c|c|c|c|}
\hline \multicolumn{2}{|c|}{$\begin{array}{l}\text { Project Name: Bechtel Nevada } \\
\text { Site Sample ID: DUPA } \\
\text { Other Sample ID: }\end{array}$} & \multicolumn{3}{|c|}{ Chain-of-Custody Number: NONE } & \multicolumn{2}{|c|}{ Matrix: Soil } \\
\hline Method Number & Radionuclide & $\begin{array}{l}\text { Laboratory } \\
\text { Sample ID }\end{array}$ & $\begin{array}{l}\text { Activity } \\
\text { (pCi/g) }\end{array}$ & $\begin{array}{l}2 \sigma \text { TPU } \\
(\mathrm{pCi} / \mathrm{g})\end{array}$ & $\begin{array}{c}\text { Total Error } \\
(\mathrm{pCi} / \mathrm{g})\end{array}$ & $\begin{array}{c}\mathrm{MDA} \\
(\mathrm{pCi} / \mathrm{g})\end{array}$ \\
\hline EPA 901.1 & $K-40$ & NTS03-4958-05 & 23.8 & 2.25 & 3.27 & 0.234 \\
\hline EPA 901.1 & $00-60$ & NTS03-4958-05 & 0.001 & 0.022 & 0.022 & 0.031 \\
\hline EPA 901.1 & $Y-88$ & NTS03-4958-05 & 0.010 & 0.015 & 0.015 & 0.028 \\
\hline EPA 901.1 & RU-106 & NTS03-4958-05 & -0.063 & 0.157 & 0.157 & 0.256 \\
\hline EPA 901.1 & SB-125 & NTS03-4958-05 & 0.033 & 0.044 & 0.044 & 0.077 \\
\hline EPA 901.1 & CS-134 & NTS03-4958-05 & 0.017 & 0.018 & 0.018 & 0.028 \\
\hline EPA 901.1 & CS -137 & NTS03-4958-05 & 0.047 & 0.035 & 0.035 & 0.032 \\
\hline EPA 901.1 & CE-144 & NTS03-4958-05 & 1.68 & 1.78 & 1.78 & 0.207 \\
\hline EPA 901.1 & PM-144 & NTS03-4958-05 & 0.004 & 0.016 & 0.016 & 0.027 \\
\hline EPA 901.1 & PM-146 & NTS03-4958-05 & 0.001 & 0.022 & 0.022 & 0.037 \\
\hline EPA 901.1 & EU-152 & NTS03-4958-05 & 0.029 & 0.047 & 0.047 & 0.080 \\
\hline EPA 901.1 & EU-154 & NTSO3-4958.05 & 0.000 & 0.000 & 0.000 & 0.056 \\
\hline EPA 901.1 & EU-155 & NTSO3-4958-05 & 0.283 & 0.093 & 0.098 & 0.100 \\
\hline EPA 901.1 & TL-208 & NTS03.4958-05 & 0.597 & 0.079 & 0.099 & 0.030 \\
\hline EPA 901.1 & $\mathrm{~B} !-211$ & NTS03-4958-05 & 2.82 & 0.617 & 0.678 & $0.16 \overline{3}$ \\
\hline EPA 901.1 & $B \mid-212$ & NTS03-4958-05 & 1.23 & 0.309 & 0.333 & 0.232 \\
\hline EPA 901.1 & PB-212 & NTSO3-4958-05 & 1.73 & 0.424 & 0.458 & 0.050 \\
\hline EPA 901.1 & $\mathrm{Bl}-214$ & NTS03-4958-05 & 0.917 & 0.122 & 0.152 & 0.057 \\
\hline EPA 901.1 & PB-214 & NTS03-4958-05 & 0.982 & 0.213 & 0.235 & 0.057 \\
\hline EPA 901.1 & RA-224 & NTS03-4958-05 & 1.81 & 0.650 & 0.972 & 0.572 \\
\hline EPA 901.1 & RA-226 & NTS03-4958-05 & 2.86 & 0.752 & 0.805 & 0.650 \\
\hline EPA 901.1 & $A C-228$ & NTS03-4958-05 & 1.74 & 0.246 & 0.301 & 0.109 \\
\hline EPA 901.1. & TH-234 & NTS03-4958-05 & 2.36 & 0.590 & 0.636 & 0.526 \\
\hline EPA 901.1 & $U-235$ & NTS03-4958-05 & 0.173 & 0.046 & 0.049 & 0.039 \\
\hline EPA 901.1 & U-238 & NTSO3-4958-05 & 1.42 & 3.24 & 3.24 & 5.65 \\
\hline EPA 901.1 & $A M-241$ & NTSO3-4958-05 & 0.132 & 0.125 & 0.125 & 0.182 \\
\hline
\end{tabular}

\begin{tabular}{|cllll|}
\hline Radionuclide & Laboratory Control (LC) & Labality Control Samples & \\
Gamma & $\frac{\text { Laboratory Duplicate (LD) }}{\text { SCAQC-4958-LC1 }}$ & SCAQC-4958-LD1 & Matrix Spike (MS) & Preparation Blank (PB) \\
\hline
\end{tabular}




\section{Sanford Cohen \& Associates \\ Southeastern Environmental Laboratory}

\section{Radioanalytical Results}

Report ldentification Number: V2127

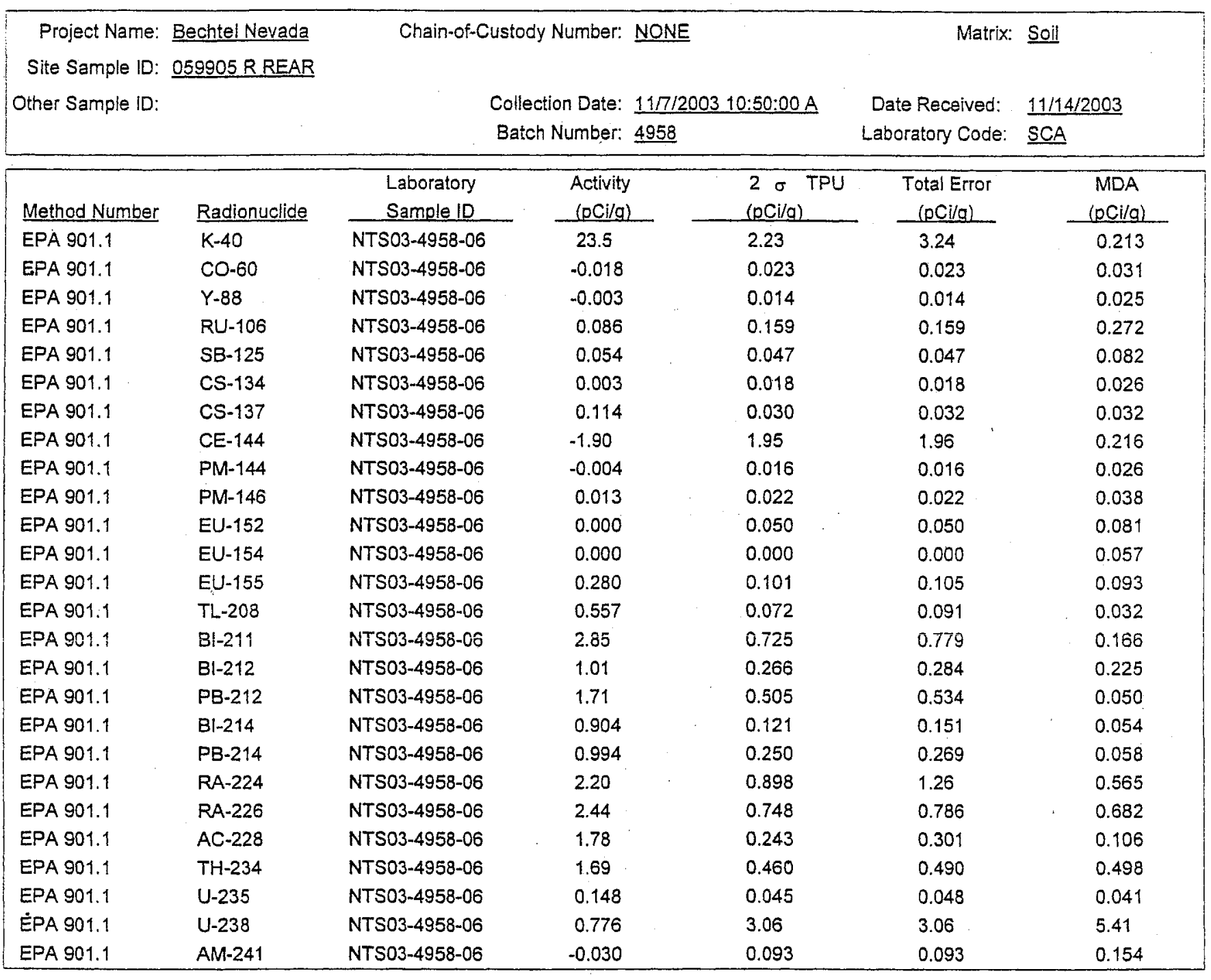

\begin{tabular}{|lllll}
\hline Radionuclide & Quality Control Samples & \\
Gamma & $\frac{\text { Laboratory Control (LC) }}{\text { SCAQC-4958-LC1 }}$ & $\frac{\text { Laboratory Duplicate (LD) }}{\text { SCAQC-4958-LD1 }}$ & Matrix Spike (MS) & Preparation Blank (PB) \\
\hline
\end{tabular}




\section{Sanford Cohen \& Associates \\ Southeastern Environmental Laboratory \\ Radioanalytical Results}

Quality Control Sample

Laboratory Control (LC1)

Report Identification Number: V2127

Project Name: Bechtel Nevada

Site Sample ID: N/A
Chain-of-Custody Number: None

Collection Date: 11/14/2003 9:00:00 A
Matrix: Soil

Date Received: $\quad 11 / 14 / 2003$ Laboratory Code: SCA

\begin{tabular}{|c|c|c|c|c|c|c|}
\hline Method Number & Radionuclide & $\begin{array}{l}\text { Laboratory } \\
\text { Sample iD }\end{array}$ & $\begin{array}{l}\text { Activity } \\
\text { (pCi/g) }\end{array}$ & $\begin{array}{l}2 \sigma \text { TPU } \\
(\mathrm{pCi} / \mathrm{g})\end{array}$ & $\begin{array}{c}\text { Total Error } \\
\text { (pCi/a) }\end{array}$ & $\begin{array}{l}\mathrm{MDA} \\
(\mathrm{pCi} / \mathrm{q})\end{array}$ \\
\hline EPA 901.1 & CO-60 & SCAQC-4958-LC1 & 16.4 & 1.59 & 2.28 & 0.061 \\
\hline EPA 901.1 & CD.109 & SCAQC-4958-LC1 & 9.41 & 2.10 & 2.30 & 1.80 \\
\hline EPA 901.1 & CS-137 & SCAQC-4958-LC1 & 25.7 & 2.59 & 3.65 & 0.089 \\
\hline
\end{tabular}

\begin{tabular}{|c|c|c|c|c|}
\hline \multicolumn{5}{|c|}{ Quality Control Samples } \\
\hline Radionuclide & Laboratory Control (LC) & Laboratory Duplicate (LD) & Matrix Spike (MS) & Preparation Blank (PB) \\
\hline Gamma & $\overline{\text { SCAQC-4958-LC1 }}$ & $\overline{S C A Q C-4958-L D 1}$ & & SCAQC-4958-PB \\
\hline
\end{tabular}




\section{Sanford Cohen \& Associates \\ Southeastern Environmental Laboratory}

Radioanalytical Results

Quality Control Sample

Duplicate (LD1)

Report Identification Number: V2127

\begin{tabular}{rrr}
\hline Project Name: Bechtel Nevada & Chain-of-Custody Number: NONE & Matrix: Soil \\
Site Sample ID: $\underline{059905 \text { LREAR }}$ & Collection Date: $11 / 7 / 2003$ 10:30:00A & Date Received: $11 / 14 / 2003$ \\
Other Sample ID: LD1 & Laboratory Code: & SCA
\end{tabular}

\begin{tabular}{|c|c|c|c|c|c|c|}
\hline Method Number & Radionuclide & $\begin{array}{l}\text { Laboratory } \\
\text { Sample ID }\end{array}$ & $\begin{array}{l}\text { Activity } \\
\text { (pCi/g) }\end{array}$ & $\begin{array}{l}2 \sigma \text { TPU } \\
(\mathrm{pCi} / \mathrm{g})\end{array}$ & $\begin{array}{l}\text { Total Error } \\
(\mathrm{pCi} / \mathrm{g})\end{array}$ & $\begin{array}{c}\mathrm{MDA} \\
(\mathrm{pCl} / \mathrm{g})\end{array}$ \\
\hline EPA 901.1 & $K-40$ & SCAQC-4958-LD1 & 23.4 & 2.21 & 3.22 & 0.234 \\
\hline EPA 901.1 & co-60 & SCAQC-4958-LD1 & -0.006 & 0.023 & 0.023 & 0.029 \\
\hline EPA 901.1 & $Y-88$ & SCAQC-4958-LD1 & 0.008 & 0.013 & 0.013 & 0.026 \\
\hline EPA 901.1 & RU-106 & SCAQC-4958-LD1 & -0.107 & 0.158 & 0.158 & 0.254 \\
\hline EPA 901.1 & SB- 125 & SCAQC-4958-LD1 & 0.014 & 0.044 & 0.044 & 0.075 \\
\hline EPA 901.1 & CS -134 & SCAQC-4958-LD1 & -0.015 & 0.018 & 0.018 & 0.025 \\
\hline EPA 901.1 & CS-137 & SCAQC-4958-LD1 & 0.171 & 0.034 & 0.038 & 0.031 \\
\hline EPA 901.1 & CE-144 & SCAQC-4958-LD1 & 0.326 & 1.84 & 1.84 & 0.209 \\
\hline EPA 901.1 & PM-144 & SCAQC-4958-LD1 & 0.005 & 0.017 & 0.017 & 0.027 \\
\hline EPA 901.1 & PM-146 & SCAQC-4958-LD1 & 0.037 & 0.022 & 0.023 & 0.039 \\
\hline EPA 901.1 & $E U-152$ & SCAQC-4958-LD1 & 0.002 & 0.048 & 0.048 & 0.079 \\
\hline EPA 901.1 & EU-154 & SCAQC-4958-LD1 & 0.000 & 0.000 & 0.000 & 0.055 \\
\hline EPA 901.1 & EU-155 & SCAQC-4958-LD1 & 0.201 & 0.083 & 0.085 & 0.101 \\
\hline EPA 901.1 & TL-208 & SCAQC-4958-LD1 & 0.571 & 0.075 & 0.094 & 0.029 \\
\hline EPA 901.1 & $B \mid-211$ & SCAQC-4958-LD1 & 2.40 & 0.619 & 0.664 & 0.168 \\
\hline EPA 901.1 & $\mathrm{Bl}-212$ & SCAQC-4958-LD1 & 1.19 & 0.300 & 0.323 & 0.228 \\
\hline EPA 901.1 & PB-212 & SCAQC-4958-LD1 & 1.51 & 0.447 & 0.472 & 0.050 \\
\hline EPA 901.1 & Bl-214 & SCAQC-4958-LD1. & 0.847 & 0.116 & 0.143 & 0.052 \\
\hline EPA 901.1 & PB-214 & SCAQC-4958-LD1 & 0.836 & 0.214 & 0.229 & 0.059 \\
\hline EPA 901.1 & RA-224 & SCAQC-4958-LD1 & 1.87 & 0.820 & 1.11 & 0.570 \\
\hline ËPA 901.1 & RA-226 & SCAQC-4958-LD1 & 2.76 & 0.863 & 0.906 & 0.619 \\
\hline EPA 901.1 & AC-228 & SCAQC-4958-LD1 & 1.66 & 0.236 & 0.289 & 0.104 \\
\hline EPA 901.1 & TH-234 & SCAQC-4958-LD1 & 2.10 & 0.503 & 0.545 & 0.499 \\
\hline EPA 901.1 & U-235 & SCAQC-4958-LD1 & 0.167 & 0.052 & 0.055 & 0.038 \\
\hline EPA 901.1 & U.238 & SCAQC-4958-LD1 & 3.51 & 3.12 & 3.14 & 5.71 \\
\hline EPA 901.1 & $A M-241$ & SCAQC-4958-LDH & -0.052 & 0.100 & 0.101 & 0.148 \\
\hline
\end{tabular}

\begin{tabular}{|c|c|c|}
\hline \multicolumn{3}{|c|}{ Laboratory Samples for Duplicates } \\
\hline Radionuclide & $\begin{array}{l}\text { Laboratory } \\
\text { Sample ID }\end{array}$ & $\begin{array}{c}\text { Duplicate of } \\
\text { Sample ID }\end{array}$ \\
\hline GAMMA & SCAQC-4958-LD1 & NTSO3-4958-01 \\
\hline
\end{tabular}




\section{Sanford Cohen \& Associates \\ Southeastern Environmental Laboratory}

Radioanalytical Results

\section{Quality Control Sample}

Duplicate (LD1)

Report Identification Number: V2127

\begin{tabular}{|c|c|c|c|}
\hline \multirow{2}{*}{$\begin{array}{l}\text { Project Name: Bechtel Nevada } \\
\text { Site Sample ID: } 059905 \text { LREAR }\end{array}$} & \multirow[t]{2}{*}{ Chain-of-Custody Number: NONE } & \multirow{2}{*}{\multicolumn{2}{|c|}{ Matrix: Soil }} \\
\hline & & & \\
\hline Dther Sample ID: LD1 & Collection Date: $11 / 7 / 2003$ 10:30:00 A & $\begin{array}{l}\text { Date Received: } \\
\text { Laboratory Code: }\end{array}$ & $\underline{11 / 14 / 2003}$ \\
\hline
\end{tabular}

\begin{tabular}{|c|c|c|c|c|}
\hline \multicolumn{5}{|c|}{ Quality Control Samples } \\
\hline Radionuclide & Laboratory Control (LC) & Laboratory Duplicate (LD) & Matrix Spike (MS) & Preparation Blank (PB) \\
\hline Gamma & SCAQC-4958-LC1 & SCAQC-4958-LD1 & & SCAQC-4958-PB \\
\hline
\end{tabular}


THIS PAGE INTENTIONALLY LEFT BLANK 
Revision: 1

Date: April 2005

\section{SAMPLE DELIVERY GROUP}

V2162 
Closure Report - CAU 167

Section: Appendix A

Revision: 1

Date: April 2005

THIS PAGE INTENTIONALLY LEFT BLANK 


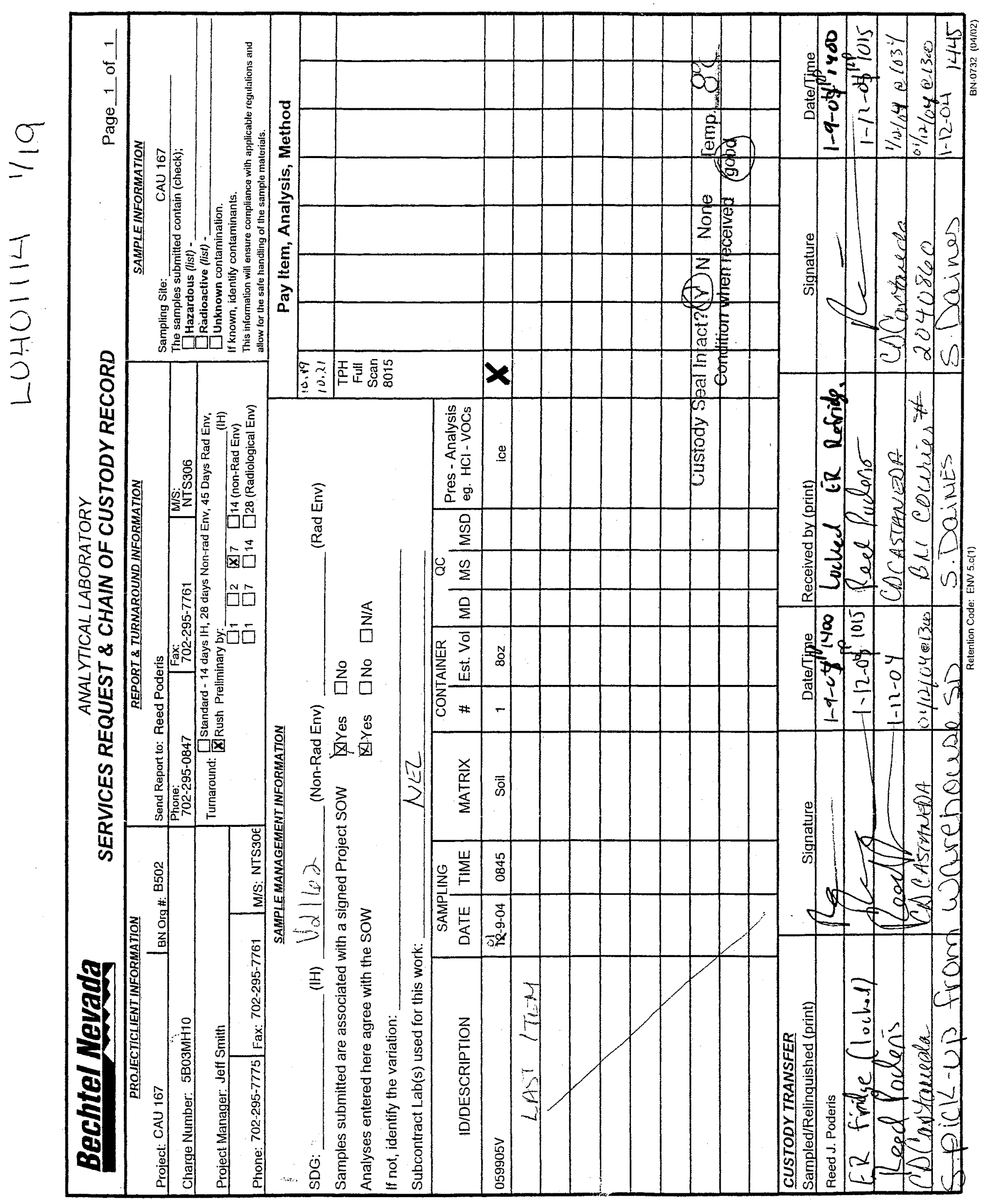


THIS PAGE INTENTIONALLY Y LEFT BLANK 
NEL Laboratories, Las Vegas

Date: $15-J a n-04$

\begin{tabular}{|c|c|c|c|c|c|c|c|}
\hline CLLENT: & Bechtel Nevada & \multicolumn{6}{|c|}{ Client Sample ID: $059905 \mathrm{~V}$} \\
\hline Lab Order: & L0401114 & \multicolumn{4}{|r|}{ Collection Date: } & \multicolumn{2}{|c|}{ 1/9/04 8:45:00 AM } \\
\hline Project: & V2162 & \multirow{2}{*}{\multicolumn{6}{|c|}{ Matrix: SOLID }} \\
\hline Lab ID: & L0401114-001 & & & & & & \\
\hline \multicolumn{2}{|l|}{ Analyses } & Result & Limit & Qual & Units & DF & Date Analyzed \\
\hline \multicolumn{2}{|c|}{ TOTAL EXTRACTABLE TPH } & \multicolumn{3}{|c|}{ SW8015M } & \multicolumn{3}{|r|}{ Analyst: FAS-L } \\
\hline \multicolumn{2}{|c|}{ Gasoline Range Organics (C8-C12) } & ND & 20 & & $\mathrm{mg} / \mathrm{kg}$ & 1 & $1 / 13 / 04$ \\
\hline \multicolumn{2}{|c|}{ Diesel Range Organics (C12-C22) } & ND & 20 & & $\mathrm{mg} / \mathrm{Kg}$ & 1 & $1 / 13 / 04$ \\
\hline \multicolumn{2}{|c|}{ Oil Range Organics (C22-C34) } & ND & 50 & & $\mathrm{mg} / \mathrm{Kg}$ & 1 & $1 / 13 / 04$ \\
\hline \multirow{2}{*}{\multicolumn{2}{|c|}{$\begin{array}{l}\text { Total Petroleum Hydrocarbons } \\
\text { Surr: } n \text {-Octacosane }\end{array}$}} & ND & 20 & & $\mathrm{mg} / \mathrm{Kg}$ & 1 & $1 / 13 / 04$ \\
\hline & & 84.1 & $34.8-139$ & & $\% R E C$ & 1 & $1 / 13 / 04$ \\
\hline
\end{tabular}

Qualifiers: ND - Not Detected at the Reporting Limit

$J$ - Analyte detected below quanititation limits

$B$ - Analyte detected in the associated Method Blank

* - Value exceeds Maximum Contaminant Level
$S$ - Spike Recovery outside accepted recovery limits

$R$ - RPD outside accepted recovery limits

E - Value above quantitation range 
THIS PAGE INTENTIONALLY LEFT BLANK 
Closure Report - CAU 167

Section: Appendix A

Revision: 1

Date: April 2005

\section{SAMPLE DELIVERY GROUP}

V2332

A-11 


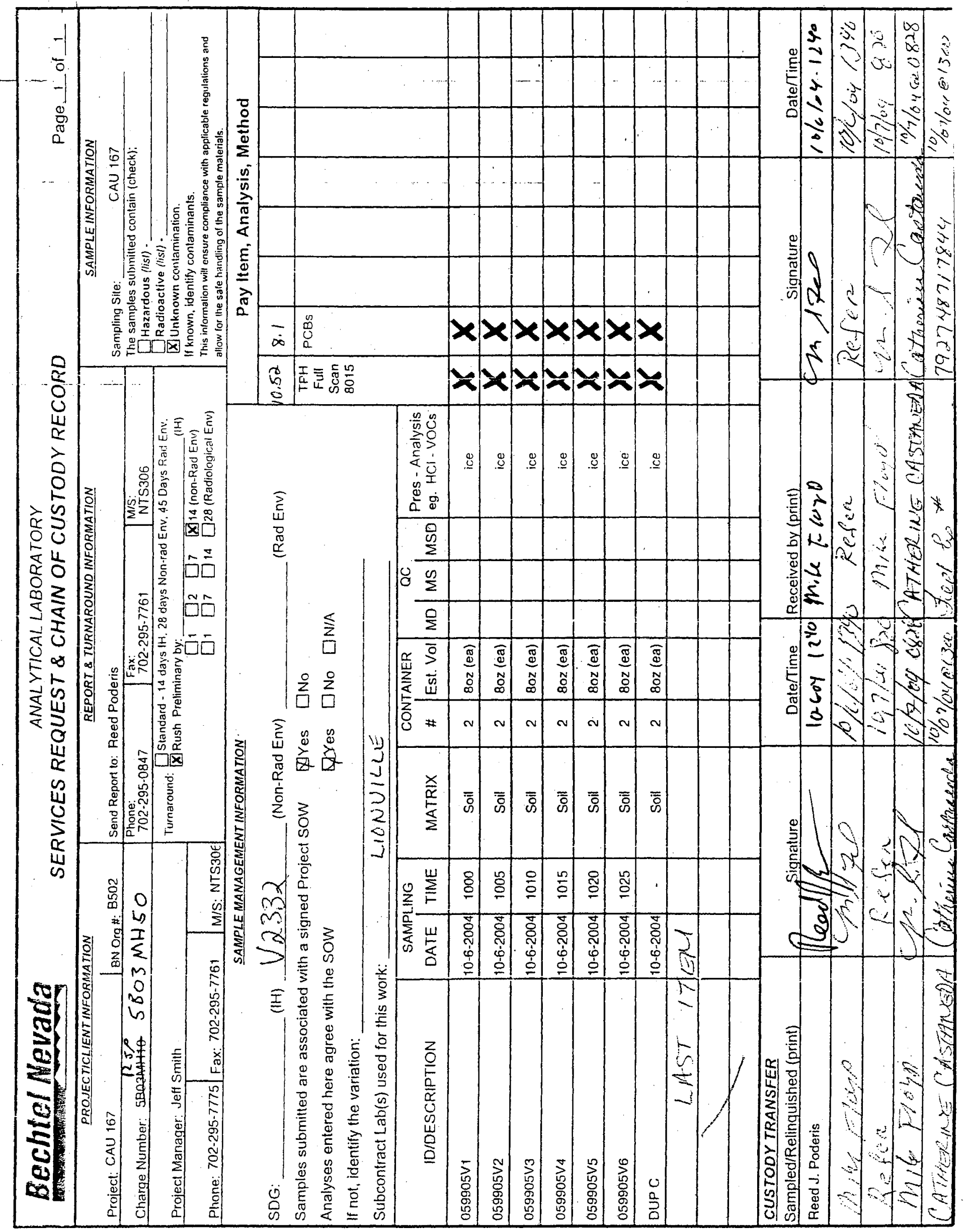




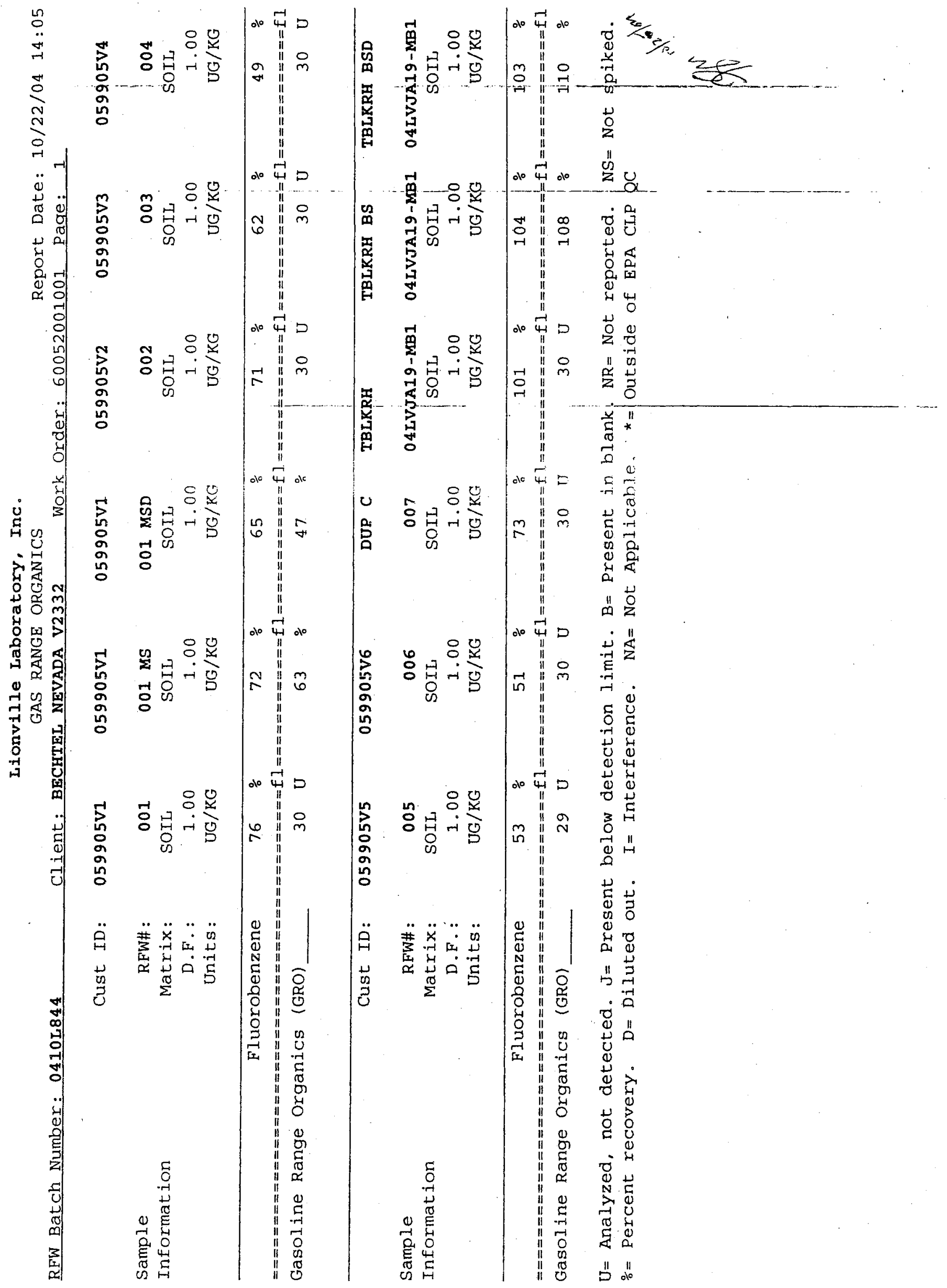




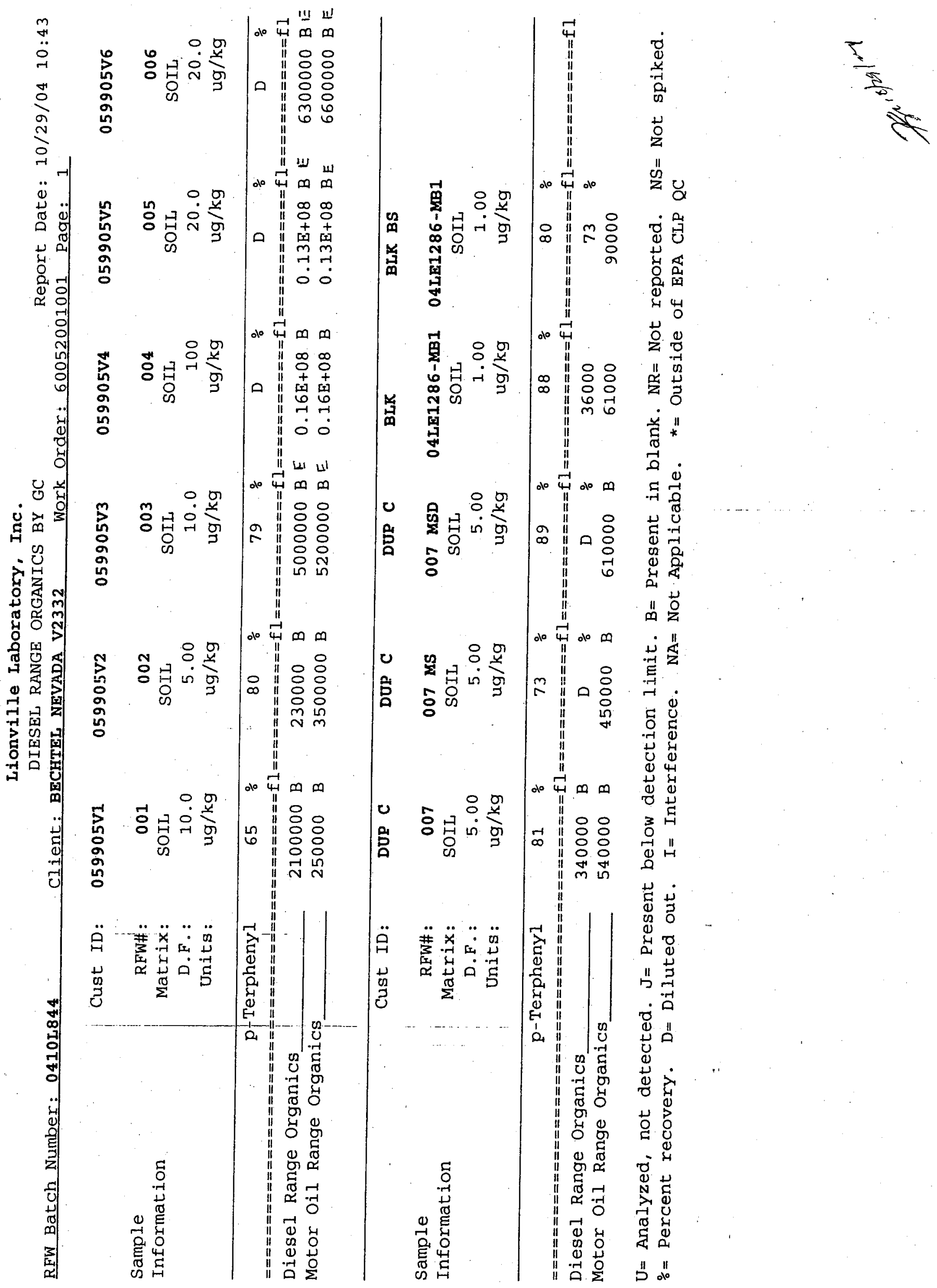




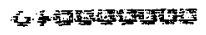

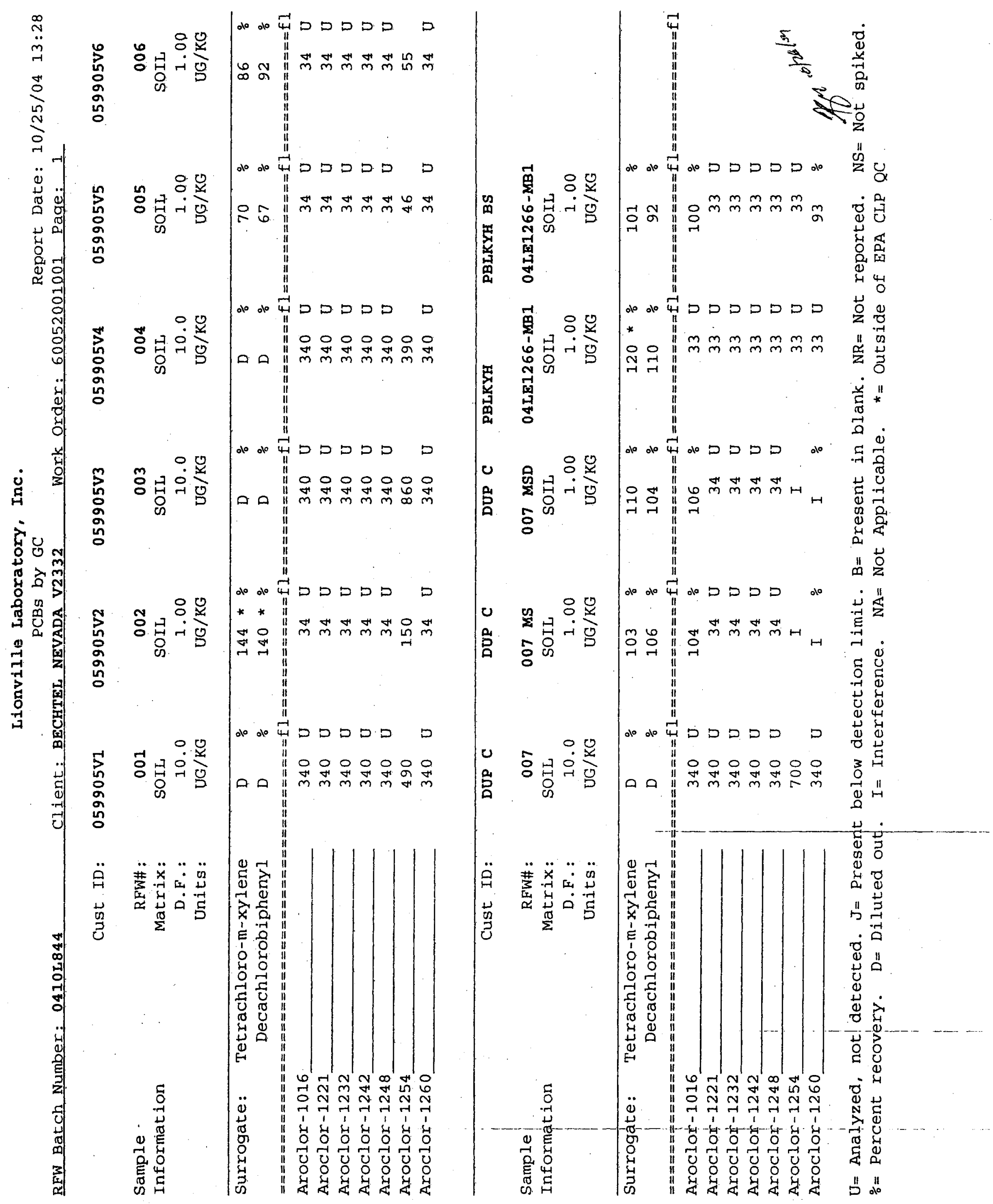


Closure Report - CAU 167

Section: Appendix A

Revision: 1

Date: April 2005

\section{SAMPLE DELIVERY GROUP}

V2376 
Closure Report - CAU 167

Section: Appendix A

Revision: 1

Date: April 2005

THIS PAGE INTENTIONALLY LEFT BLANK 


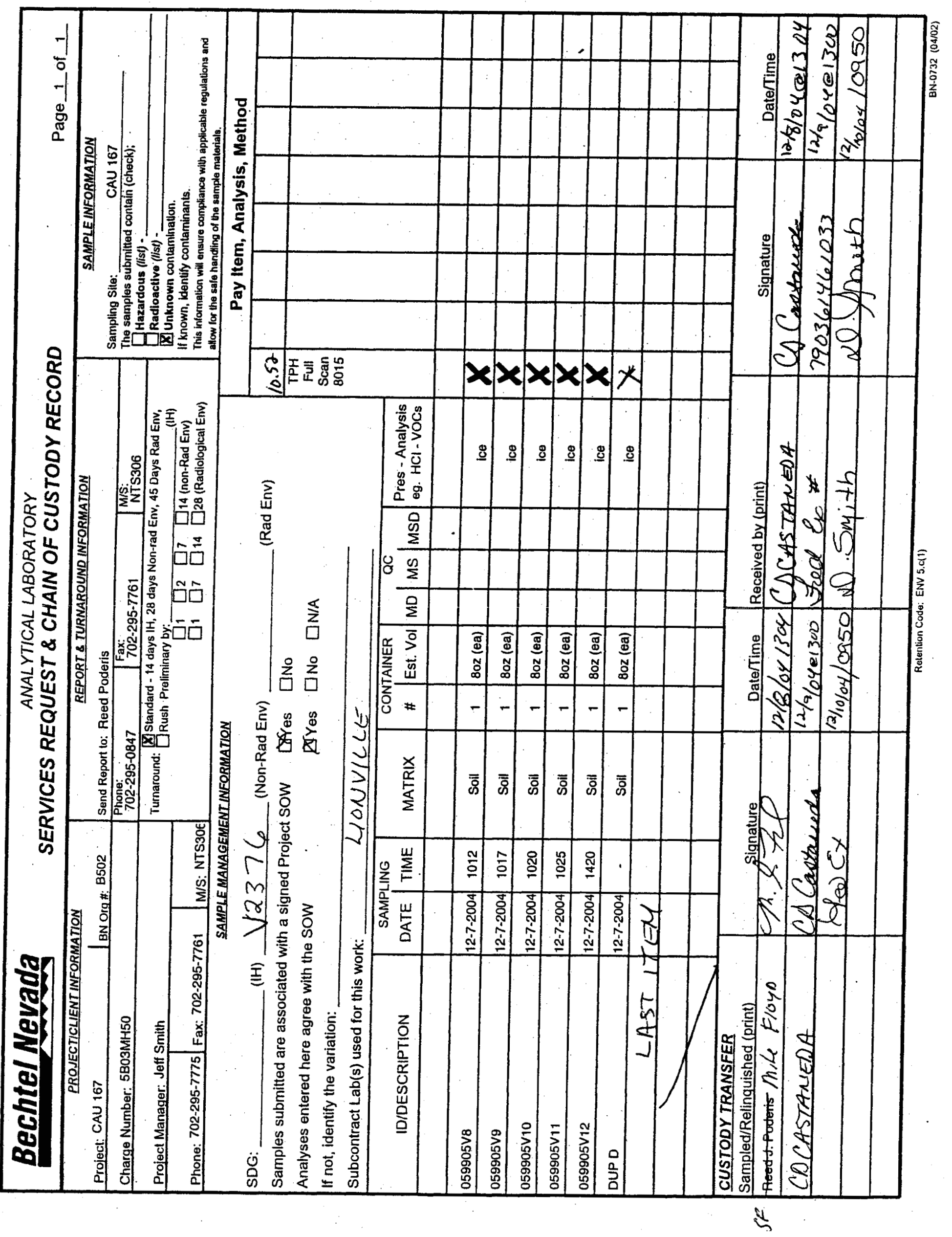


THIS PAGE INTENTIONALLY Y LEFT BLANK 


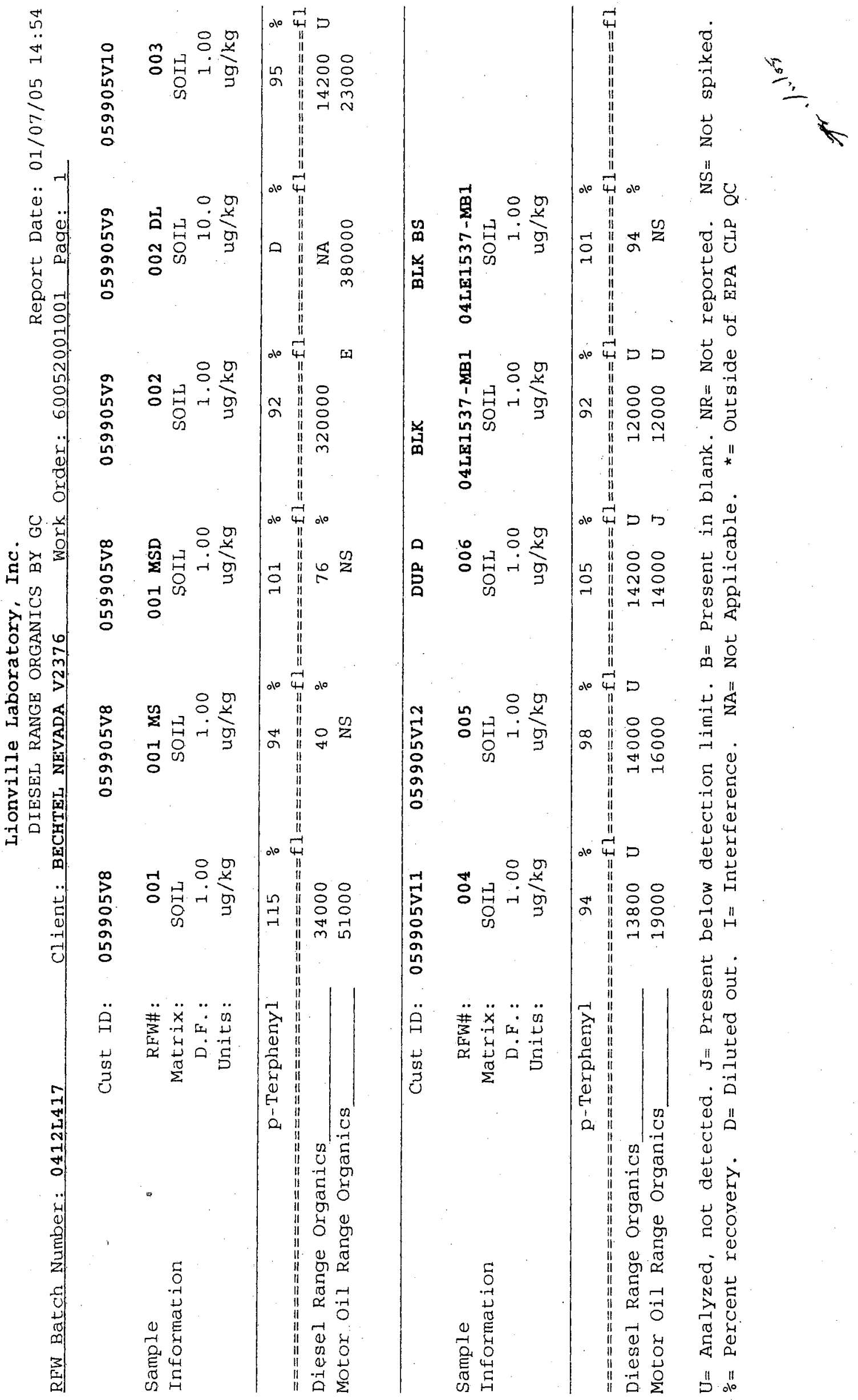




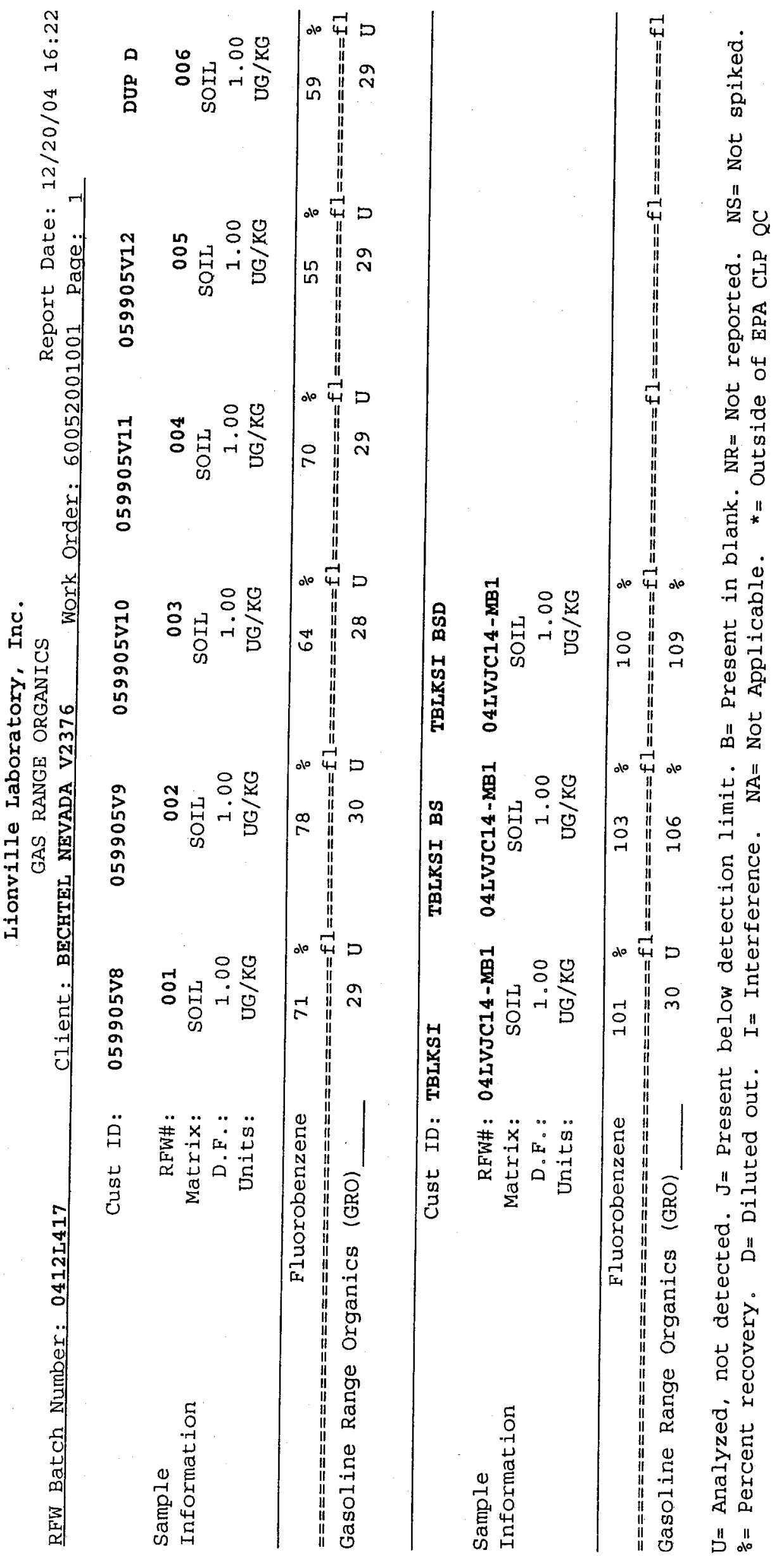


Date: April 2005

\section{APPENDIX B}

\section{SECTORED HOUSEKEEPING SITE CLOSURE VERIFICATION FORMS}


Closure Report - CAU 167

Section: Appendix B

Revision: 1

Date: April 2005

THIS PAGE INTENTIONALLY LEFT BLANK 


\section{Sectored Housekeeping Site Closure Verification Form}

Closure Verification Date: 12/07/2004

CAU Number: 167

CAS Number: 05-99-05

CAS Description: Combat Tank; Radioactive Materials

Sector Designation: NTS Sector C

Housekeeping Site General Location: Frenchman Flat

Elevation: 940 meters (m)

Northing: 4,073,275 m (UTM Zone 11) Easting: 594,201 m (UTM Zone 11)

Latitude: 36.80062

Longitude: -115.94405

Coordinate/Elevation Data Obtained from: North American Datum, 1927.

Site Access Route: Take Mercury Highway north to 5-01 Road. Continue north on 5-01 Road to 5-03 Road. Turn right (east) on 5-03 Road and proceed 1.2 miles to a dirt trail that leads to the site. The tank is visible from the road.

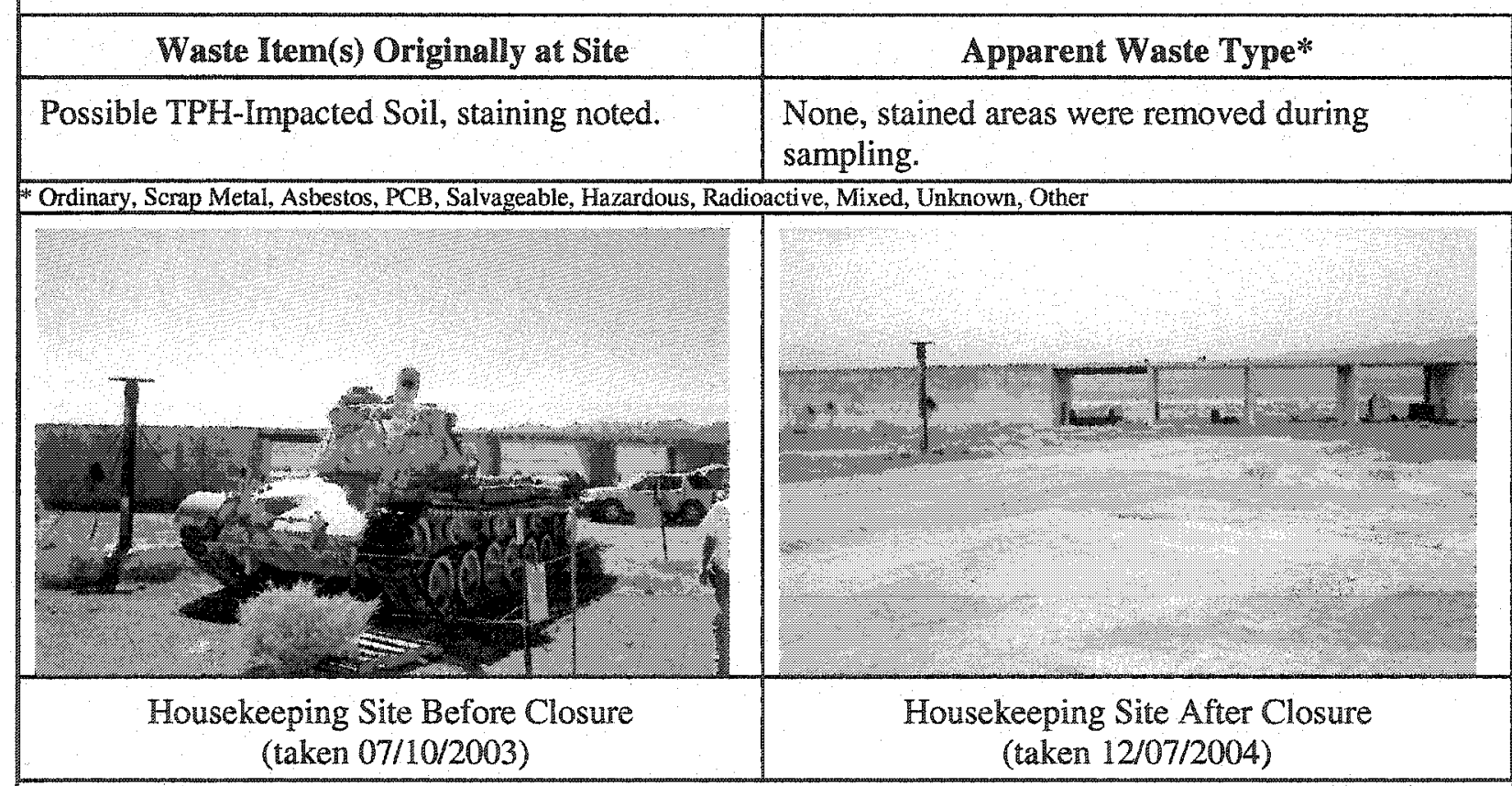

Current Site Description/Observations: Combat tank was relocated to Area 1 for training purposes. Approximately 40 cubic yards of TPH-impacted soil was removed, verification samples were collected, and the excavation was backfilled with clean fill and graded. An "A through $\mathrm{K}^{\text {" }}$ risk assessment was made and included in the Closure Report.

X No Turther Action Tequired at Houselkeping Site

Reed J. Poderis, CEM

Corrective Action Coordinator/Designee

Rue Powe 12-07-2004

Signature

Date 


\section{Sectored Housekeeping Site Closure Verification Form}

Closure Verification Date: 07/10/2003

CAU Number: 167

CAS Number: 19-19-02

CAS Description: Trash Pit

Sector Designation: NTS Sector G

Housekeeping Site General Location: U19ab

Elevation: 1,828 meters (m)

Northing: 4,123,225 m (UTM Zone 11)

Easting: $559,739 \mathrm{~m}$ (UTM Zone 11)

Latitude: 37.25366

Longitude: -116.32636

Coordinate/Clevation Data Obtained from: North American Datum, 1927.

Site Access Route: Take Mercury Highway north to Pahute Mesa Road. Turn left (west) on Pahute Mesa Road and proceed to RSM 19-P69. Turn left (west) on the dirt road at RSM 19-P69 and proceed to the U-19ab Crater fence.

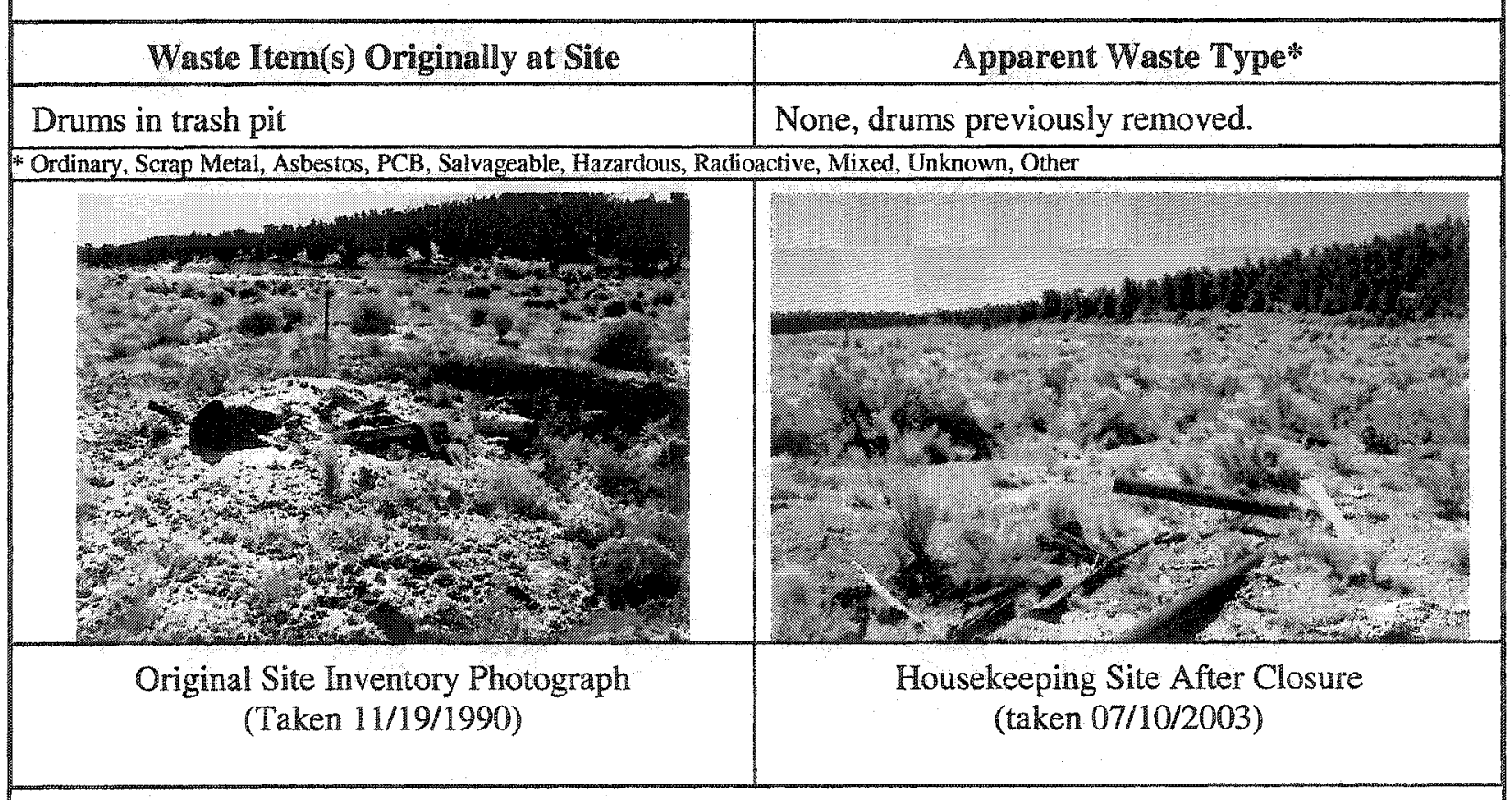

Currenen Site Description/Observations: No drums remained at this site during the Preliminary Assessment or the Bechtel Nevada closure activities. There is other debris present. However, the site is inaccessible by vehicle as the site is located within a potential crater area.

X No Further Action Required at Housekeeping Site

\begin{tabular}{lll} 
Reed J. Poderis, CEM & Reed/for & $7-10-20 \mathrm{cos}$ \\
\hline Corrective Action CoordinatorDesignee & Signathe & Date
\end{tabular}




\section{APPENDIX C:}

\section{NATIONAL ENVIRONMENTAL POLICY ACT EVALUATION CHECKLIST}


Closure Report - CAU 167

Section: Appendix C

Revision: 1

Date: April 2005

THIS PAGE INTENTIONALLY LEFT BLANK 


\section{U.S. DEPARTMENT OF ENERGY}

\section{NATIONAL NUCLEAR SECURITY ADMINISTRATION NEVADA OPERATIONS OFFICE NEPA ENVIRONMENTAL EVALUATION CHECKLIST}

\begin{tabular}{|c|c|c|}
\hline $\begin{array}{l}\text { FOLLOW ATTACHED PROCED } \\
\text { A. Project/Activity Title (Attach a brief des } \\
\text { CAUs 167, 210, 289, 390, \& 395: Housek } \\
286 \text { (006 }\end{array}$ & $\begin{array}{l}\text { PLETING CHECKLIST } \\
\text { od project) } \\
\text { ure/Cleanup Activities }\end{array}$ & $\begin{array}{l}\text { Date } \\
10 / 14 / 2003\end{array}$ \\
\hline $\begin{array}{l}\text { Project Location } \\
\text { NTS, Various Areas }\end{array}$ & \multicolumn{2}{|c|}{ Proposed By (If other than NNSA/NV) } \\
\hline $\begin{array}{l}\text { NNSANVV Line Management Organization } \\
\text { Environmental Restoration Division }\end{array}$ & \multicolumn{2}{|c|}{$\begin{array}{l}\text { NNSA/NV Project/Program Manager } \\
\text { Sabine Curtis }\end{array}$} \\
\hline $\begin{array}{l}\text { Anticipated Start Date } \\
\text { November } 1,2003\end{array}$ & \multicolumn{2}{|c|}{ DOE/HQ Program Office (If applicable) } \\
\hline
\end{tabular}

ENVIRONMENTAL CONSIDERATIONS: If any phase of the projectlactivity involves any of the following considerations, check yes and explain in project description. See NV-16A for consideration guidelines and examples.

\begin{tabular}{|l|c|c|c|l|c|c|c|}
\hline \multicolumn{1}{|c|}{ Consideration } & Yes & No & Unk & \multicolumn{1}{|c|}{ Consideration } & Yes & No & Unk \\
\hline 1. Noise & $\mathrm{X}$ & & & 10. Liquid Effluents & & $\mathrm{X}$ & \\
\hline 2. Air Emissions & & $\mathrm{X}$ & & 11. Underground Storage/Septic Tanks & & $\mathrm{X}$ & \\
\hline 3. Explosives & & $\mathrm{X}$ & & 12. Utility Systems (PCBs) & & $\mathrm{X}$ & \\
\hline 4. Petroleum/Fuel Storage/Use & $\mathrm{X}$ & & & 13. Environmental Restoration Site & $\mathrm{X}$ & & \\
\hline 5. Pesticide/Herbicide Use & & $\mathrm{X}$ & & 14. Change in Existing Drainage Pattern & & $\mathrm{X}$ & \\
\hline 6. Hazardous/Toxic Substances & $\mathrm{X}$ & & & 15. Surface Disturbance/Excavation & $\mathrm{X}$ & & \\
\hline 7. Solid Waste & $\mathrm{X}$ & & & 16. Cultural/Historic Resources & & & $\mathrm{X}$ \\
\hline 8. Mixed Waste & $\mathrm{X}$ & & & 17. Biological/Tortoise Resources & & & $\mathrm{X}$ \\
\hline 9. Radioactive Materials & $\mathrm{X}$ & & & & & & \\
\hline
\end{tabular}

DO NOT TYPE OR WRITE BELOW THIS LINE. FOR ESHD USE ONLY.

$B$. Is the project/activity included in the final NTS EIS and the ROD or other NEPA document? Yes $\mathrm{X}$ (complete Sections $\mathrm{C}, \mathrm{D}$, and E) No ___ (complete Sections $\mathrm{D}, \mathrm{E}$, and F)

C. This project/activity is included in the NTS EIS/ROD (or other NEPA document) under the following section and page number:

NTS EIS Volume 1, Appendix A, A.3.1.3 - Environmental Restoration Program; Industrial Sites Project

$D$. Does the proposed project/activity require any local, state, or federal permits or notifications?

Yes $\underline{X} \quad$ No

E. Does the proposed project/activity relate to the FFCA or FFACO agreements?

Yes $\underline{X} \quad$ No

F. If, based on the project description and the preliminary environmental considerations noted above, the proposed action fits within a class of action listed in Subpart D of 10 CFR 1021, write in the space below, the paragraph number and short title from the appropriate table of contents of Subpart $D, A p p e n d i x B, C$, or $D$, for a CX, EA, or EIS. If the proposed action does not fit within any class of action, write "Not Listed" below.

\section{G. NEPA COMPLIANCE OFFICER DETERMINATION OR RECOMMENDATION:}

I have determined that the proposed action as described in Item $A$ above, has been adequately addressed for the purpose of NEPA in the NTS EIS. No further analysis or documentation is required pursuant to NEPA.

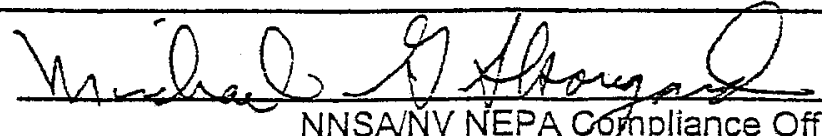


NV-2004-002

\section{CAUS $167,210,286,390, \& 395:$ HOUSEKEEPING SITES CLOSURE/CLEANUP ACTIVITIES}

\section{Project Description}

The purpose of this project is to remove the various debris located at several Corrective Action Units (CAUs). All CAUs are housekeeping sites, located at the Nevada Test Site (NTS). CAU 167 is located in Areas 5, 18, and 19 and consists of four Corrective Action Sites (CASs). CAU 210 is located in Areas 10, 12 and 15 and consists of 4 CASs. CAU 286 is located in Areas $1,2,3,4$, and 6 and consists of twelve CASs. CAU 390 is located in Areas 9,10 , and 12 and consists of six CASs. CAU 395 is located in Area 19 and consists of ten CASs. A detailed list of the CASs and descriptions is provided in the FFACO (1996). Each CAU is listed below, with a brief description of the types of debris present in the CASs.

\section{CAU 167}

Includes approximately 40 boxes of rock cores, stained soil below a disabled combat tank, and a trash pit with metal and wood debris. Some of the rock cores and the soil below the combat tank are possibly radioactive.

\section{CAU 210}

Includes several empty metal cans and buckets and a large piece of scrap metal. The large piece of scrap metal may be radioactive.

\section{CAU 286}

Includes primarily pieces of lead shielding in various locations. A pile of concrete is also included. Some of the wastes may be radioactive. The lead material is hazardous. However, the majority of the lead material is salvageable.

\section{CAU 390}

Includes asphalt, paraffin wax, and tar spills. One drum with several gallons of unknown liquid is also included. Some of the waste may be radioactive and or hazardous/toxic.

\section{CAU 395}

Includes concrete, oil, and asphalt spills. Several spills of unidentified materiais are also included. Some of the waste may be radioactive and or hazardous/toxic.

\section{Environmental Considerations}

1. Noise levels: Elevated noise levels may result from the operation of a backhoe and/or loader equipment. Personnel not directly involved with operation of this equipment will be kept back at least 15 feet while equipment is in use. The equipment operator will follow the instructions as directed in the Site Specific Health and Safety Plan.

4. Petroleum/Fuel Storage Use: Heavy equipment on site will use petroleum fuel. No fuel will be stored on site outside of the equipment. Absorbent pads will be used if equipment appears to be leaking petroleum.

6. Hazardous/Toxic Substances: Several sites contain lead, PCB or TPH-impacted and/or sanitary waste and soil. No other chemical hazards are known to exist. Personnel will be required to follow the safety procedures outlined in the Site Specific Health and Safety Plan and Job Hazard Analysis. Wastes will be disposed of either on the NTS or offsite, depending on analysis results.

7. Solid Waste: Any solid waste that may be generated from project activities will be disposed of at the NTS in a designated landfill.

8. Mixed Waste: Any waste which is classified as a mixed waste will be disposed of at the NTS in a approved mixed waste facility.

9. Radioactive Materials: Several sites are in a URMA, CA, or RMA. Radiologically-impacted soil and manufactured items in these areas may require disposal at either the Area 3 or Area 5 Radioactive Waste Management Site.

13. Environmental Restoration Site: These sites are included in the FFACO as Corrective Action Unit $176,346,350,351$, 352, and 523. (See Project Description). 
15. Surface Disturbance/Excavation: Equipment will travel off-road on previously disturbed areas. Equipment will also be used to help remove surface debris. Minor excavations may be required to removed stained soil at spill locations. All excavations will be performed under the appropriate permit.

16. Cultural/Historic Resources: Archaeologists will evaluate and document these sites for historical value. Cultural surveys will be conducted as necessary at these sites prior to project activities.

17. Biological/Tortoise Resources: Biological pre-activity surveys may be required in areas where off-road travel or excavation will occur. Surveys will be conducted prior to any suriace-disturbing activities. 
THIS PAGE INTENTIONALLY Y LEFT BLANK 


\section{APPENDIX D}

\section{NEVADA ENVIRONMENTAL RESTORATION PROJECT DOCUMENT REVIEW SHEET}


Closure Report - CAU 167

Section: Appendix D

Revision: 1

Date: April 2005

THIS PAGE INTENTIONALLY LEFT BLANK

D-2 


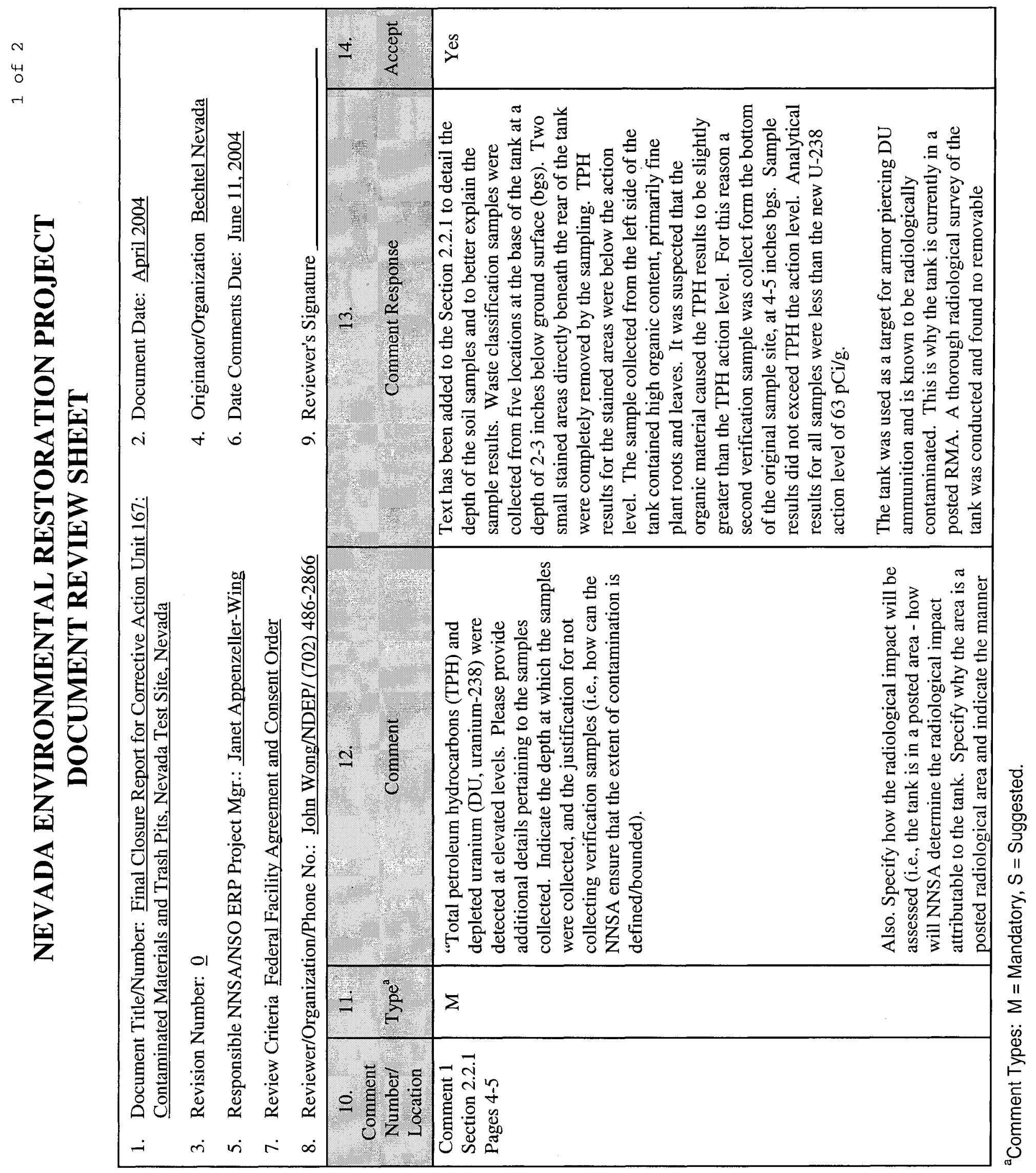




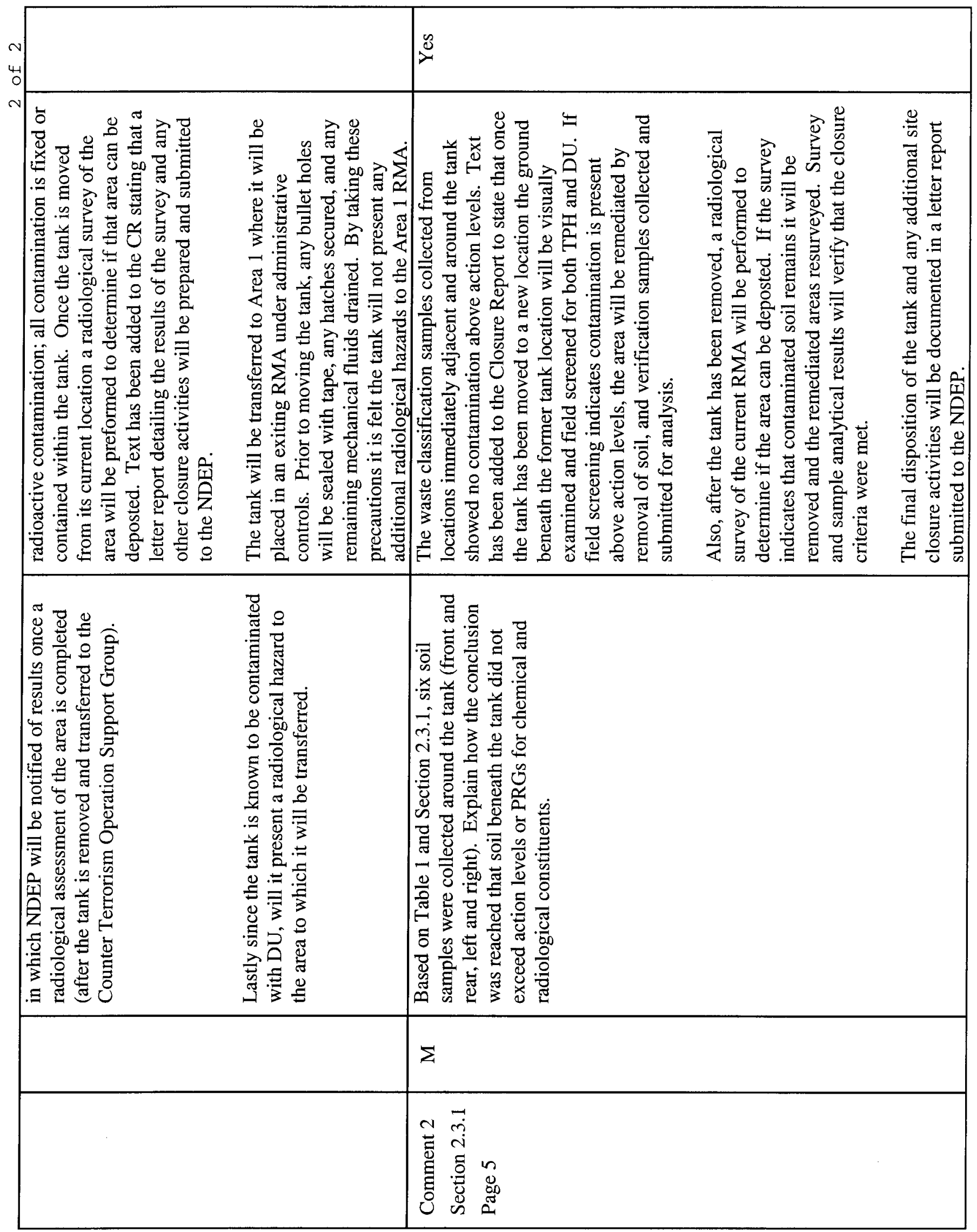


Closure Report - CAU 167

Section: Distribution List

Revision: 1

Date: April 2005

\section{LIBRARY DISTRIBUTION LIST}


Closure Report - CAU 167

Section: Distribution List

Revision: 1

Date: April 2005

THIS PAGE INTENTIONALLY LEFT BLANK 
U.S. Department of Energy

National Nuclear Security Administration

Nevada Site Office

Technical Library

P.O. Box 98518, M/S 505

Las Vegas, NV 89193-8518

U.S. Department of Energy

Office of Scientific and Technical Information

P.O. Box 62

Oak Ridge, TN 37831-0062

Southern Nevada Public Reading Facility

c/o Nuclear Testing Archive

P.O. Box 98521 , M/S 400

Las Vegas, NV 89193-8521

Manager, Northern Nevada FFACO

Public Reading Facility

c/o Nevada State Library \& Archives

Carson City, NV 89701-4285
1 (Uncontrolled)

1 (Uncontrolled, electronic copy)

2 (Uncontrolled, electronic copies)

1 (Uncontrolled, electronic copy) 
Closure Report - CAU 167

Section: Distribution List

Revision: 1

Date: April 2005

THIS PAGE INTENTIONALLY LEFT BLANK 